\title{
MODIFICATION OF QUORUM SENSING IN BACTERIAL CULTURES
}

\author{
Ph.D. Thesis
}

\section{Zoltán Gábor Varga}

Department of Medical Microbiology and

Immunobiology

Faculty of Medicine

University of Szeged

$$
\begin{gathered}
\text { Szeged } \\
2014
\end{gathered}
$$




\section{Publications related to the thesis}

I. Szabó MA, Varga GZ, Hohmann J, Schelz Z, Szegedi E, Amaral L, Molnár J. Inhibition of quorum-sensing signals by essential oils. Phytother. Res. 2010; 24(5):782-6.

\section{IF: 2.068}

II. Varga GZ, Szabo MA, Schelz Zs, Szegedi E, Amaral L, Molnár J. Quorum Sensing Inhibition by Phenothiazines and Related Compounds. Lett Drug Design Discovery. 2011; 8: 133-137.

\section{IF: 0.85}

III. Varga GZ, Armada A, Cerca P, Amaral L, Subki AM, Savka M, Szegedi E, Kawase M, Motohashi N, Molnár J. Inhibition of Quorum Sensing and Efflux Pump System by Trifluoromethyl Ketone Proton Pump Inhibitors. In Vivo. 2012; 26:277-286

\section{IF:1.22}

IV. Varga GZ, Szabó AM, Kerényi M, Molnár J. Interference in quorum sensing signal amongst microbial species. Acta Microbiol Immunol Hung. 2012; 9(4):477-486

IF: 0.65 


\section{Abbreviations}

5-FU 5-fluorouracil

ACP acyl carrier protein

AHK Alpha-hydroxyketone

AHL acyl homoserine lactone

AI autoinducer

AIP autoinducer peptide

AO acridine orange

A. tumefaciens Agrobacterium tumefaciens

C. albicans Candida albicans

CAI cholera autoinducer

CSP competence stimulating peptide

CV026 Chromobacterium violaceum 026

C. violaceum Chromobacterium violaceum

DMSO dimethyl sulfoxide

DPD 4,5-dihydroxy-2,3-pentadione

DSF diffusible signal factor

EB Ethidium bromide

E. cloaceae Enterobacter cloaceae

E. coli Escherichia coli

EPS extracellular polymeric substances

HHQ 2-heptyl-4-(1H)-hydroxyquinolone

H. pylori Helicobacter pylori

IDU iodine deoxyuridine

LB Luria-Bertani 
LB* modified Luria-Bertani

MHA Mueller-Hinton agar

MHB Mueller-Hinton broth

MIC minimum inhibitory concentration

OD optical density

P. aeruginosa Pseudomonas aeruginosa

PBS phosphate-buffered saline

PDA potato dextrose agar

PMF proton motive force

PQS Pseudomonas quinolone signal

$\boldsymbol{P}$. syringae Pseudomonas syringae

QQ quorum quenching

QS quorum sensing

RFF relative final fluorescence

SAH S-adenosylhomocysteine

SAM S-adenosylmethionine

S. aureus Staphyllococcus aureus

S. pneumoniae Streptococcus pneumoniae

SRH S-ribosylhomocysteine

S. typhimurium Salmonella typhimurium

THMF methyl-2,3,3,4-tetrahydroxytetrahidrofuran

TI tumour inducing

TLC thin layer chromatography

TZ thioridazine

V. cholerae Vibrio cholerae 
V. fischeri Vibrio fischeri

V. harveyi Vibrio harveyi

V. paradoxus Variovorax paradoxus

X. campestris Xanthomonas campestris

X. fastidiosa Xilella fastidiosa 


\section{Table of contents}

1. Introduction 1

1.1. QS 2

1.2. QS in Gram-negetive bacteria 3

1.2.1. LuxI/LuxR system of $V$. fischeri 3

1.2.2. LasI/LAsR-RhII/RhIR system of Pseudomonas aeruginosa (P. aeruginosa) 3

1.2.3. The TraI/TraR QS system of Agrobacterium tumefaciens (A. tumefaciens) 4

1.3. QS in Gram-positive bacteria 5

1.3.1. The QS system of Staphylococcus aureus (S. aureus) 6

1.3.2. The QS system of $S$. pneumonia 6

$\begin{array}{ll}\text { 1.4. QS signal molecules } & 7\end{array}$

$\begin{array}{ll}\text { 1.4.1. AHLs } & 7\end{array}$

1.4.2. Peptide-type autoinducers $\quad 8$

$\begin{array}{ll}\text { 1.4.3. AI-2 } & 8\end{array}$

1.4.4 Pseudomonas quinolone signal PQS 9

$\begin{array}{ll}\text { 1.4.5. The DSF } & 10\end{array}$

$\begin{array}{ll}\text { 1.4.6. AI-3 } & 10\end{array}$

1.4.7. Alpha-hydroxyketones (AHKs) 10

1.5. Quorum quenching 11

1.5.1. Inhibition of signal production 11

1.5.2. QS signal degradation and inactivation 12 
2.1. Tricyclic compounds

2.2. Other chemicals

2.4. Essential oils

2.5. Bacterial strains

2.9. Evaluation of complex formation between N-hexanoyl-DL-homoserine lactone and QS inhibitors

2.10. Taxonomic identification of EZF 10-17 and analysis of its AHL production 20

2.11. MIC of each TF on CV026 and E. coli AG100

2.12. Assessment of the effects of each TF on the activities of the efflux pump systems of CV026 and E. coli AG100 
3.4. QS and efflux pump inhibitor activity of TF compounds 28

3.5. Bacterial-bacterial interactions in QQ 34

$\begin{array}{ll}\text { 4. Discussion } & 38\end{array}$

$\begin{array}{ll}\text { 5. Summary } & 43\end{array}$

6. Összefoglaló $\quad 44$

$\begin{array}{ll}\text { 7. Acknowledgement } & 46\end{array}$

$\begin{array}{ll}\text { 8. References } & 47\end{array}$ 


\section{Introduction}

Quorum is a Greek word. In the ancient Hellenic and Roman forums, it was necessary for the members of the senate to form at least a minimal majority in order for them to make a decision. The group of persons whose number was sufficient for them to be able to accept or reject an act was the quorum.

In general, microbes have numerous genes which become activated only when the bacterial population owersteps a threshold concentration. The term used to describe this population size-dependent gene regulation is quorum sensing (QS), involving communication between bacteria.

In spite of the ancient origins of the word "quorum", QS is a relatively new area of science. When Leuweenhoek first glimpsed inside the bacterial world, it was thought that microbes live in a blind and deaf world, where all cells live their own lives without any influence from others. The first signs of the collapse of this theory, was the discovery of the competence stimulating factor of Streptococcus pneumoniae (S. pneumoniae) in 1965 (1). It was obserwed that this bacterium needs an extracellular peptide to reach the competent state, and this molecule can be produced only at a high population size density. This is very useful, because there is no reason for a bacterium to waste energy reaching the competent state if there are insufficient cells in the near environment. The first direct evidence and the birth of QS emerged 5 years after this interesting discovery. This was the light production of Vibrio fischeri ( $V$. fischery), (2). This bacterium can colonize the light organ of several species of deepwater animals, includeing squids and fish. In this special organ, all nutrients are given to reach a high cell density. The wall of this organ is usually very flexible and fish can press water out of it. When this happens, the cell density of the vibrios increases, and light is produced. The first-described QS system was the $V$. fischeri LuxI/LuxR system (3), which is a characteristic feature in other G- bacterial species too.

After these initial discoveries, it seemed that QS is very rare and almost unique in the bacterial world, influencing merely a few and not too important bacterial features. Nowadays, this has completely changed. As more and more QS systems have been discovered, it has become clear that bacterial communication does not occur in only a few isolated cases. QS is an essential part of bacterial life. The bacterium, with its QS system, has leverage, which is why QS is widely prevalent in the microbial world. With communication systems, microbes can accommodate to their habitat like multicellular organisms, and can fight as a unit against environmental impacts, other bacteria or the host immune system. Group 
behaviour is probably the most developed bacterial lifestyle. In a complex multispecies biofilm, every bacterium knows its place, and what is the best to do for the community and for itself. Division of labour is an evident thing in multicellular eukaryotes, but in prokaryotic biofilms too. QS has a special role not only in prokaryotic-prokaryotic, but also in eukaryoticprokaryotic communication. The human body contains 10 times more bacterial cells than human cells, and most bacteria generally live in full harmony with us. It is clear that, it is virtually impossible to maintain this symbiosis without communication. We have hormones which affect our flora, and our symbionts also deploy QS signals which have effects on our cells. QS is also a very important phenomenon for the pathogenic bacteria. Signal molecules contribute directly to pathogenesis via the organization of biofilms or the synchronized production of virulence factors.

Antibiotic resistance is the most important problem in modern microbiology. Bactericidal or bacteriostatic compounds exert strong selective pressure on microbes. Because of the irresponsible use of antibiotics, pathogenic bacteria nowadays often display resistance to at least a few medicines. The appearance of multidrug-resistant strains which tolerate the latest antibiotics too enhances this problem. There is an urgent need to discover new antimicrobial, antipathogenic and antivirulence drugs. QS inhibitors may be a good alternative to solve this situation.

\subsection{QS}

QS is a widely prevalent feature of both Gram-negative and Gram-positive bacteria. There are many different types of QS systems and signal molecules in the bacterial world, but each system relies on the same basics. Each bacterium synthesizes signal molecules in low amounts. When the population density is low, the number of signal molecules is also low, when the number of bacteria increases, the concentration of QS molecules increases. When the concentration of signal molecules exceeds a threshold concentration, a positive feedback starts, and the bacteria increase the production of signal molecules. At this very high concentration of QS molecules, they bind their receptors. The nature of the receptors can differ considerably in each case, but in the end of the process is the same: the initiation of target gene transcription. 

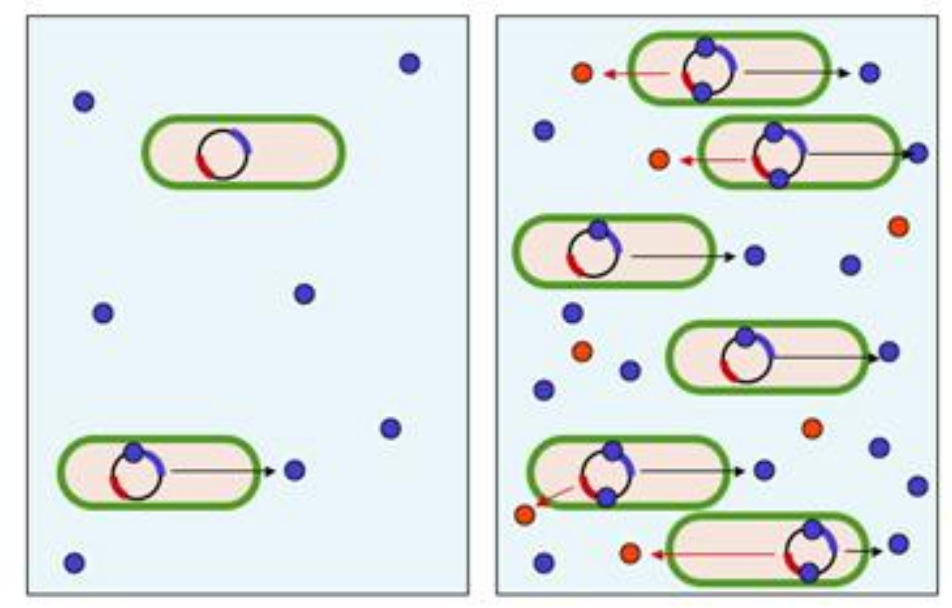

Figure 1.

Schematic outline of QS.

Left side: Low concentrations of bacteria and signal molecules (blue circles).

Right side: When the concentration of bacteria increases, the amount of signal molecules increases too. when it reaches the threshold concentration, binding to the receptors occurs and activates the transcription of the target genes (4).

\subsection{QS in Gram-negative bacteria}

\subsubsection{LuxI/LuxR system of $V$. fischeri}

The first described QS was the LuxI/LuxR system of $V$ fischeri (3). Two proteins, LuxI and LuxR, control the synthesis of the enzyme luciferase. The bacterium synthesizes the signal molecules with the acyl homoserine lactone (AHL) synthase LuxI. When the AHL reaches the threshold concentration, it can bind to LuxR, the cytoplasmic receptor $(5,6)$. The LuxR-AHL complex activates the transcription of the luciferase operon. The LuxR-AHL complex also induces the expression of luxI because it is encoded in the luciferase operon. This positive feedback leads to a flood of more and more AHL molecules to the environment, which can diffuse freely to the receptor and activate the transcription of the structure genes. The end of this process is the light production of the bacteria. LuxI/LuxR-type AHL-dependent QS systems are highly prevalent in G-bacteria. It mainly takes place in intraspecies communication too.

\subsubsection{LasI/LAsR-RhII/RhIR system of Pseudomonas aeruginosa (P. aeruginosa)}

P. aeruginosa is an abundant, opportunistic pathogenic bacterium which lives in soil and natural waters, and frequently colonizes and organizes biofilms in taps, air conditioners and 
other water-associated equipment. Although this bacterium rarely causes infections in healthy adults, it involves a great health risk. This bacterium is responsible for most nosocomial infections, and it exhibits very strong antibiotic resistance.

P. aeruginosa has two LuxI/LuxR homologues, LasI/LasR and RhlI/RhlR (7). LasI and RhlI are autoinducer (AI) synthases that produce the signal molecules 3OC12HSL and C4HSL (8, 9). LasR and RhlR are specific AHL receptors. The LasR-AHL complex activates the expression of lasI and a variety of other target genes, and also activates the RhlI/RhlR system. There are hundreds of genes which are under QS control in $P$. aeruginosa. Some of them are induced by only one AI, while some need both 3OC12HSL and C4HSL to activate. There are also genes which are activated by either C4HSL or 3OC12HSL $(10,11) . P$. aeruginosa has a LuxR "solo" receptor which does not have a cognate synthase pair. This is called QscR, and is activated by 3OC12HSL (12). The QS system of Pseudomonas species is very complex. Besides the two LuxI/LuxR type synthase/receptor pairs and the LuxR solo, it uses other types of AIs for the stringent control of QS. The Pseudomonas quinolone signal (2-heptyl-3hydroxy-4(1H)-quinolone; PQS) is used only by $P$. aeruginosa, its precursor 2-heptyl-4(1H)hydroxyquinolone (HHQ), is used by other Pseudomonas species and Burkholderia spp. as well. Both PQS and HHQ act as AIs via the interaction of the transcriptional regulator PqsR (13).

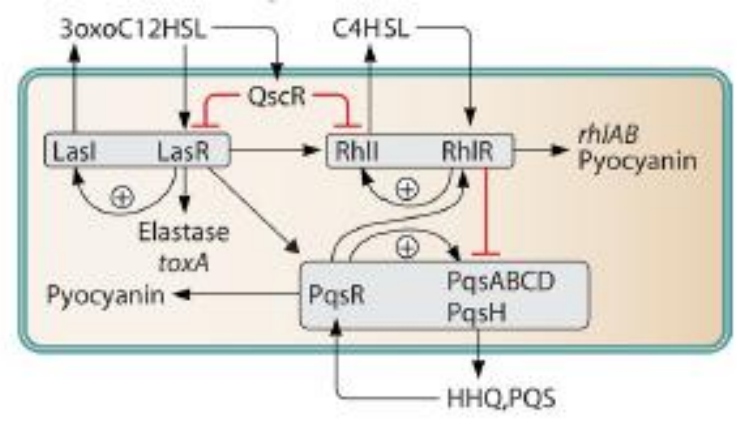

Figure 2.

The QS system of $P$. aeruginosa (14)

\subsubsection{The TraI/TraR QS system of Agrobacterium tumefaciens (A. tumefaciens)}

A. tumefaciens is a tumour-inducing (TI) phytopathogenic bacterium which causes infections mainly in arboreal dicotyledonous plants. The bacterium penetrates into the host through injured tissues, and causes crown gall tumours via the intercalated T-DNA (located in the TI plasmid). These tumours produce opines which the bacteria use as carbon source. Besides the opine genes, TI plasmid encodes phytohormones, which are necessary for the tumour growth, and the genes traI and traR, which are responsible for the QS of the bacteria $(15,16)$. 
The QS system of A. tumefaciens is quite interesting, because this bacterium needs an opine signal from the infected plant to activate the QS system responsible for the mobilization of the TI plasmid. These molecules are detected by the cytoplasmic receptor OccR (15). The OccRopine complex induces the expression of traR. After the binding of their AHL, the TraR receptors induce the expression of structure genes, which are responsible for the TI plasmid replication. These genes also include traM, which is responsible for the down-regulation of the process.

\subsection{QS in Gram-positive bacteria}

The Gram-positive bacteria do not have any LuxI/LuxR-type homologues; they mainly use different peptide molecules as autoinducers. Usually, these oligopeptides cannot penetrate through the membrane; specialized active transporters are needed to deliver them into the external space. The AI peptides (AIPs) are subject to various modification events, such as processing or cyclization. The detection of the AIPs can be extra- or intracellular, but most of the receptors are localized extracellularly. When the receptors binds the AIPs, a phosphorylation-dephosphorylation cascade starts which reaches the response regulator and activates or represses the QS target genes (17).

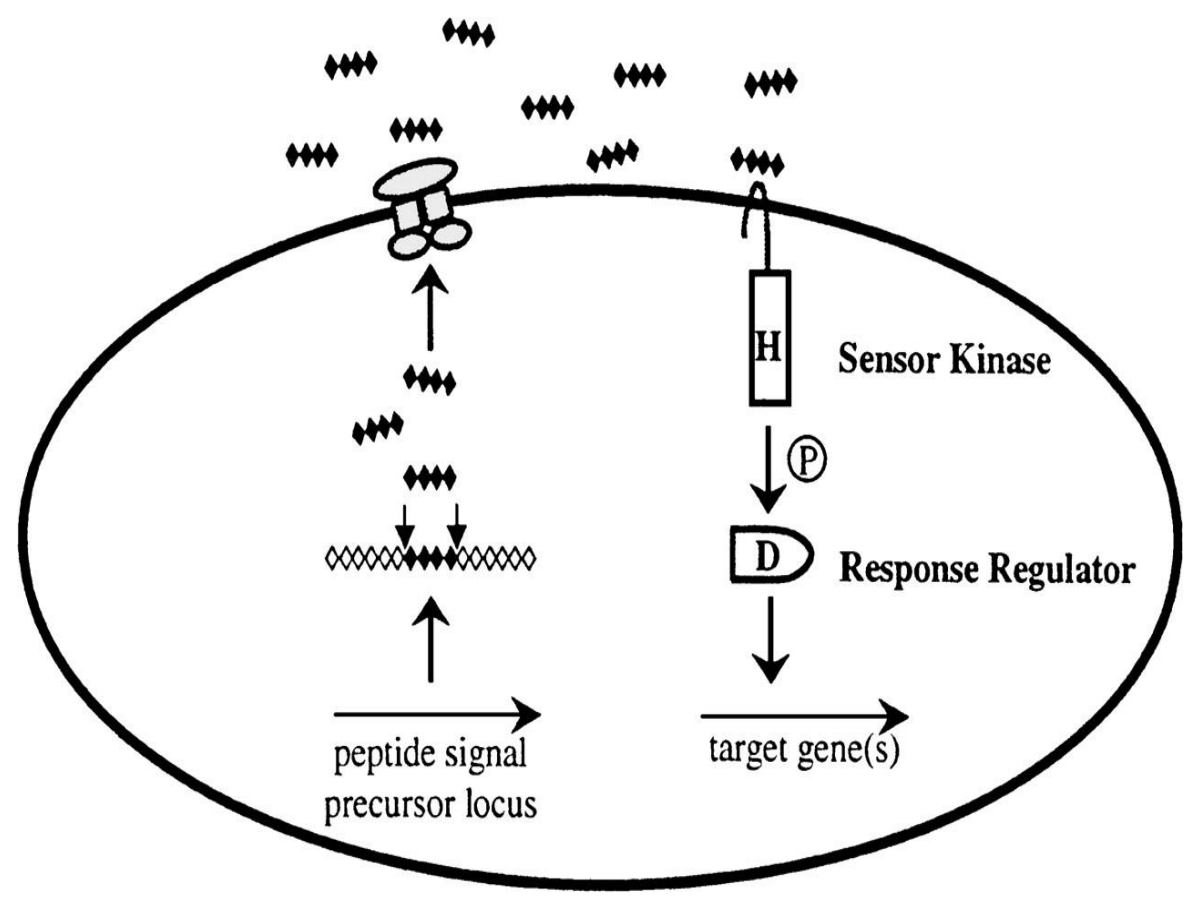

Figure 3.

The mechanism of peptide based QS (18). 


\subsubsection{The QS system of Staphylococcus aureus (S. aureus)}

S. aureus is a widely prevalent bacterium which causes numerous human diseases. It can nearly infect all kinds of tissues e.g. skin, bone, the lungs and the nervous system. It has great resistance to most antibiotics, and has evolved multiresistant strains, that tolerate all kinds of antibiotics. S. aureus strains use interesting QS-mediated strategies to cause diseases. At low cell density they express factors which promote attachment, biofilm formation and colonization, while at high cell density they produce proteases and toxins, which promote dissemination and infection. This density-dependent pathogenicity in S. aureus is regulated by the RNAIII molecule, the level of which is mediated through the AgrC/AgrA QS system. The AIP of $S$. aureus is encoded by agrD. The AgrD molecule is transported and modified with a thiolactone ring by the AgrB transporter. The AgrC receptor binds the AIP extracellularly, this complex leads to the phosphorylation of AgrA and the phosphorylated AgrA then induces the expression of RNAIII. This regulatory RNA represes the expression of biofilm formation factors and promotes the expression of toxins and proteases. RNAIII also induces the expression of the agrBDCA locus, which increases the levels of AIPs (19).

Interestingly, these AIPs and therefore the S. aureus-es belong in 4 different groups. Each type of signal molecule competitively blocks the receptors of the others. The bacteria which colonize first, therefore kill or inhibit the colonization of the bacteria from the other groups (20).

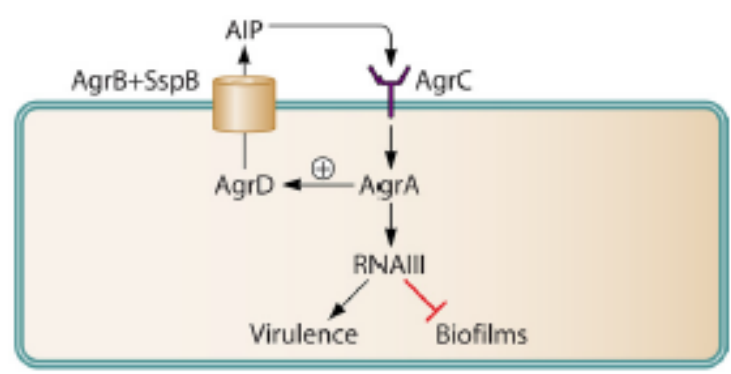

\section{Figure}

The QS system of S. aureus (14)

\subsubsection{The QS system of $S$. pneumoniae}

The QS system of S. pneumoniae was the earliest investigated QS system, (although when Tomas carried out his research, this area of science did not exist). It was revealed that $S$. pneumoniae needs an extracellular peptide, called a competence stimulating pheromone, to reach the competence state $(1,21)$. Nearly 30 years later Pestova described the QS system of this bacterium. ComC is the precursor peptide of the CSP (competence stimulating peptide) AI. This molecule is secreted out of the cell through the ComAB ABC transporter. When the 
CSP molecules reach the threshold concentration, they bind their receptors, called ComD. This AIP-receptor complex launces a phosphorylation-dephosphorylation cascade, which finally activates the transcription of the comX gene. The ComX protein is essential for the transcription of the genes which take part in the competence (22).

\subsection{QS signal molecules}

QS is population size-dependent gene regulation, mediated by small signal molecules called AIs. The natures of these molecules are very different, but most belong in 3 groups: AHLs are mainly used by Gram-negative bacteria, autoinducer II (AI-2) is used by both Gram-negatives and Gram-positives, and AIPs are used by Gram-positives. Some bacteria use AIs which do not fit these groups, e.g. the PQS diffusible signal factor (DSF) or autoinducer III (AI-3).

\subsubsection{AHLs}

AHL-s are the most common signal molecules of Gram-negative bacteria. The first discovered signal molecule was the $V$. fischeri 3OC6-HSL, which catalyses luciferase production. Many other bacteria use the same AHL to communicate, e.g. Pseudomonas syringae, Erwinia carotovora and Pseudomonas stewarti. In these species, these compounds influence the virulence and plant colonization. The length of the acyl side-chain in the AHL molecules can vary in between 4 and 18 carbon atoms. The lactone ring is conserved, but they can also differ in the saturation state of the acyl side-chain and the oxidation state at carbon 3. These molecules are usually synthesized by LuxI-type AHL synthase, using acylated acyl carrier proteins (acyl-ACPs) and S-adenosylmethionine as substrate (23).

Gram-negative bacteria can use only one AHL molecule, e.g. V. fischeri, or can use a multiple signal system, e.g. P. aeruginosa. This microbe uses two types of AHLs, 3oxoC12-HSL and C4-HSL, supplemented with the PQS and HHQ.

The AHLs mainly takes part in intraspecies communication. The receptors of these molecules are usually AHL-specific, but there are other examples. In Chromobacterium violaceum $(C$. violaceum), the bacterium which uses C6-HSLs to supervise violacein production, the AHL receptor can bind other types of AHLs with a short acyl side-chain.

The AHL receptors are usually cytoplasmic receptors for short-chain AHLs, and membranebound sensor kinases for long-chain AHLs. The short-chain AHLs can freely diffuse in and out of the cell, but long-chain AHLs need active transport to move to the external space. 
Most species use signal/receptor pairs to produce and respond to the AHL molecules. In some cases, there are also orphan receptors, or LuxR solos which can detect distinct AHL signals. These receptors do not have cognate LuxI synthase, e.g. SidA in Escherichia coli (E. coli) (12).

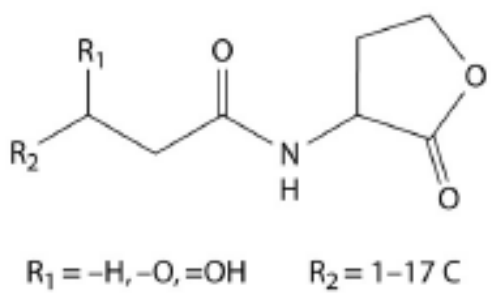

Figure 5.

The AHL molecule (14)

\subsubsection{Peptide-type autoinducers}

AIPs are mainly used by Gram-positive bacteria. These signals are synthesized ribosomally. A large precursor peptide is usually synthesized first, and after the cleavage can be modified with lactone or thiolactone rings, lanthionines or isoprenyl groups. (24-26). In all cases, specialized active transporters are needed to move the AIPs out of the cell. The transport proteins usually ensure the modification events too. The modified oligopeptides are detected extracellularly, by a two-component membrane-bound sensor histidine kinase. After the binding a phosphorylation-dephosphorylation cascade starts, which reaches the response regulator, and the activated response regulator promotes or represses the target genes. In some cases, small linear AIPs are transported back into the cell, where they directly influence the response regulation, e.g the PrgX system in Enterococcus faecalis, or the PlcR and NprR systems in Bacillus thuringiensis (27-29).

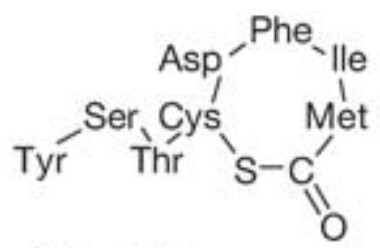

Figure 6.

AIP-1 in S. aureus (14)

\subsubsection{AI-2}

AI-2 is the universal signal molecule in bacteria. It is widely prevalent in both Gram-positive and Gram-negative species. More than a third of the currently investigated bacteria use AI-2 molecules for interspecies communication. The AI-2 systems are usually complemented with AHL (in Gram-negatives) or AIP (in Gram-positives) -based QS. 
AI-2 is generated from S-adenosylhomocysteine (SAH), which is formed when Sadenosylmethionine (SAM) releases the activated methyl group. SAH is converted by Psf (5'methylthioadenosine/S-adenosylhomocysteine nucleosidase) to S-ribosylhomocysteine (SRH) $(30,31)$. LuxS catalyses the cleavage of SRH to homocysteine and 4,5-dihydroxy-2,3pentadione (DPD). This molecule spontaneously cyclizes into two isomers, S-2-methyl2,3,3,4-tetrahydroxytetrahydrofuran-borate (S-THMF-borate) and non-borated R-2-methyl2,3,3,4-tetrahydroxytetrahydrofuran (R-THMF) (32). Both enantiomers have AI-2 activity, and are detected by different bacterial species. The AI- 2 molecules are relatively membraneimpermeable; active transport is needed to move them in and out of the cell. The YdgG protein in E. coli is the only AI-2 exporter so far known, but other mechanisms of AI-2 transport must exist (33). There are also some black spots in the receptor binding of AI-2 molecules. Three kinds of AI-2 receptors are known. The LuxP family is found only in Vibrios spp.. This periplasmic binding protein is typically associated with ATP binding casettes (ABC) (34). The ligand of this receptor is S-THMF-borate $(32,35)$.

Other well-known AI-2 receptors belong in the LsrB family. This high-affinity substratebinding periplasmic protein also interacts with the ABC transport system, called Lsr (36). The LsrB family is typically present in enteric bacteria and the members of the Rhizobiaceae and Bacillaceae and have high affinity for the R-THMF isomer of DPD $(35,37)$. Agregatinobacter actinomycetemcomitans and Haemophilus influenzae use other type of receptors as well for the sensing of AI-2s, the RbsB proteins, which have high homology (above $70 \%$ ) with the ribose $\mathrm{ABC}$ transporter $(38,39)$.
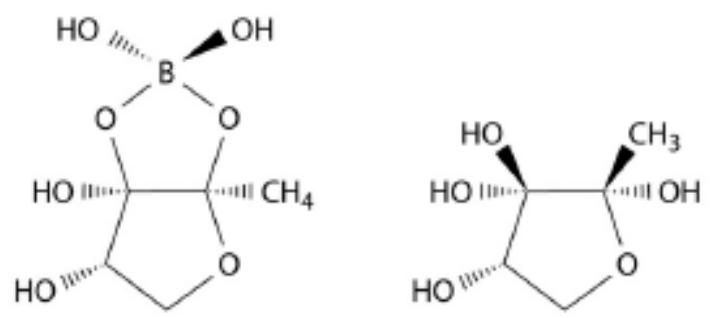

Figure 7

The AI-2 of $V$. harvei (left) and S. enterica (right) (14)

\subsubsection{Pseudomonas quinolone signal PQS}

The PQS and its precursor HHQ both act as QS signal molecules via the PqsR transcriptional regulator. The PQS is found only in P. aeruginosa, but HHQ appears in many Pseudomonas and Burkholderia spp. $(40,13)$. 


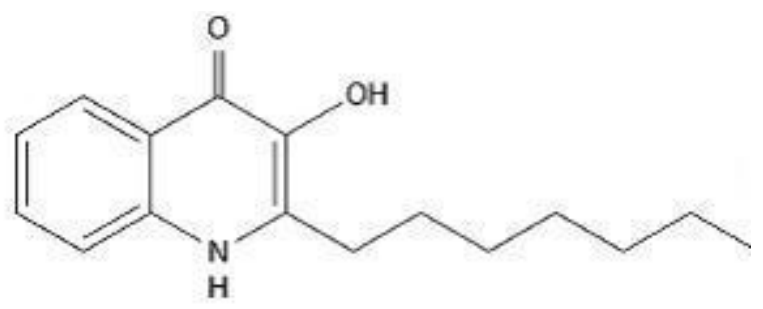

Figure 8.

The PQS molecule.

\subsubsection{The DSF}

DSF (cis-11-methyl-2-dodecenoic acid) is present in many plant pathogenic bacteria e.g. Xanthomonas campestris (X. campestris), Burkholderia cenocepacia and Xilella fastidiosa (X. fastidiosa). The mechanism of signal detection differs between species, but after the binding they share a general feature: all influence the intracellular level of cyclic di-GMP $(41,42)$.

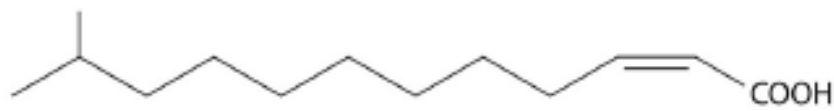

Figure 9.

The DSF signal of $X$. campestris (14)

\subsubsection{AI-3}

Although the structure of AI-3 is not yet known, it must be similar to the human hormones epinephrine and norepinephrine. This QS molecule produced is by the members of the commensal enteric flora and intestinal pathogens. In E. coli and Salmonella typhimurium (S. typhimurium), the detection of AI-3 and also the hormones epinephrine and norepinephrine occurs via the two-component QseC/QseB system $(43,44)$. This is an interesting example how we can influence the flora via hormones and how the bacteria can affect their host via QS molecules.

\subsubsection{Alpha-hydroxyketones (AHKs)}

One of the firstly identified AHK was the 3-hydroxytridecan-4-one (Cholera autoinducer I (CAI-1)) in Vibrio cholerae (V. cholerae). It produced by the enzyme CqsA from the substrates $(S)$-2-aminobutyrate and decanoyl coenzyme A. The receptor of CAI-1 is CqsS sensor kinase, which have effect on LuxU and LuxO. These proteins also influenced by AI-2 and AHL dependent QS systems in V. cholerae and Vibrio harveyi. Above Vibrios, Legionella pneumoniae also use AHKs as QS molecules (45). 


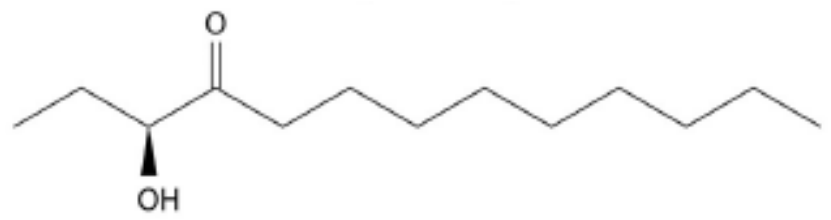

Figure 10.

The CAI-1 molecule (14)

\subsection{Quorum quenching}

Bacteria with different QS systems gain numerous benefits. They can monitor the density of their own population and those of other bacteria and eukaryotes too. They can coordinate and optimize their gene expression in a density-dependent manner. The cost of signal molecule production is very low and is usually associated with necessary cell metabolic pathways (46). For example, a bacterium does not gain leverage and waste much energy if it produces antibiotics when the cell number is not large enough to produce it in sufficient concentration. Hence it is necessary to produce signal molecules to optimize the production of difficult and expensive molecules. QS is essential in bacterial life, and many strategies have therefore been developed to disrupt it in bacterial-bacterial, and also prokaryotic-eukaryotic interactions. The mode of interaction with other QS systems can be very different, but the 3 attack points are the same: the synthesis of the signal molecule, the signal molecule and the signal detection.

\subsubsection{Inhibition of signal production}

The first step of QS is the biosynthesis of signal molecules, and numerous inhibitors therefore have the aim of this target. Evidence has been found in the inhibition of AHL, AI-2, peptidetype autoinducer and PQS production. AHL signals are produced from SAM and acyl-ACPs by acyl-HSL synthases, e.g. LuxI or AinS-type synthases. Some antimicrobials, e.g. diazobromines and triclosan, inhibit FabI (NADH-dependent enoyl-ACP reductase), the enzyme which catalyses the production of acyl-ACPs (47). Another example is found in the phytopathogenic bacterium Burkholderia glumae. The J8C8 molecule is competitivein inhibiting acyl-ACP utilization, and thereby inhibits the production of C8HSL (48). The SAM analogues, S-adenosylcysteine, S-adenosylhomocysteine and sinefungin also inhibit AHL production (22). 5'-Methylthioadenosine/S-adenosylhomocysteine nucleosidase (MTAN) is involved in both the AHL and AI-2 production, and is also necessary in cell metabolic pathways (22). Inhibition of MTAN results in aberrant grown, and not only in decreased signal production. Even so, some tested MTAN inhibitors, immucillin A and DADMe-ImmA 
derivatives, have proved to be good inhibitors $(49,50)$. Besides these molecules, AI-2 production is also impaired by different LuxS inhibitors. Enzime LuxS is probably the best target to reduce AI-2 production. S-Anhydroribosyl-L-homocysteyl and S-homoribosyl-Lcysteine were the first molecules identified as this type of inhibitors. Both are competitive inhibitors, though unfortunately with very weak effects (51). The most potent LuxS inhibitors were synthetized by the Shen's group: compounds 10 and 11 had the greatest effects (52). Halogenated furanones also inhibit AI-2 production to various degrees (53). The synthesis of the PQS and HHQ, the signal molecules produced by Pseudomonas species, can be inhibited by anthranilate analogues. Methyl anthranilate influences the PQS production in P. aeruginosa (54). Farnesol, the signal molecule of Candida albicans ( $C$. albicans), also inhibits the PQS production of P. aeruginosa. Interestingly, this opportunistic fungal pathogen frequently causes mixed infections with this bacterium (55).

The targets involved in the synthesis of AIPs are usually essential for the growth of cells too. Most QSI compounds also have bactericidal activity. There have been only a few studies on this theme. One of them related to the fungal secondary metabolite product ambuic acid, which can inhibit cyclic AIP biosynthesis in many bacterial species (56).

\subsubsection{QS signal degradation and inactivation}

Most QSI compounds use signal degradation as the mode of action. This is therefore the most studied field of QQ. There are numerous examples in AHL, AI-2, PQS, AIP and DSF signal degradation.

AHL molecules recruit a homoserine lactone ring and a 4-18 carbon atom acyl side-chain. The lactone ring is spontaneously hydrolysed at alkaline $\mathrm{pH}$, and is also spontaneous restored at acidic $\mathrm{pH}$. Through modification of the $\mathrm{pH}$ level, bacteria and higher organisms can interact with microbes and communicate with AHL molecules. In most cases the point of attack is more direct, and specific enzymes are used to degrade AHLs. There are 3 main categories: lactonases, acylases and oxidoreductases. AHL lactonases hydrolyse the ester bond on the homoserine lactone ring. The structure of the lactone ring is conserved, and most of lactonases therefore have very wide substrate specificity. Gram-positive microbes and higher organisms usually use this type of QQ. The first examples were found in Bacillus species and the aiiA (AI inactivation) gene in them was identified (57). The purified lactonases inactivate numerous types of AHLs. To produce enzymes which attack the lactone ring is not confined to microbes. For example, human paraxonase 1,2 and 3 (PON1-3), mainly produced by airway epithelial cells, also have lactonase activity $(58,59)$. Studies have revealed the 
differences between these 3 proteins. PON1 and PON3 have very wide substrate specificities, but both have lactonase activity. PON2 does not have such a wide substrate specificity but has the greatest activity against AHLs (60-62). AHL acylases hydrolyse the acyl-amide bond between the lactone ring and acyl tail. The substrate specificity of this molecule is much stricter, than in lactonases. The first acylase enzyme was inentified in Variovorax paradoxus (V. paradoxus). This bacterium is able to use various kinds of AHL as energy source (63). AHL acylases are found in various other bacteria too e.g. AhlM in Streptomices sp. strain M664 (64), HacA and HacB in P. syringae (65 Shepherd 2009) and PvdQ in P. aeruginosa (66). The third and probably the least known enzyme family which can disrupt AHL molecules are the oxidoreductases. This was first discovered in Rhodococcus erythropolis. Like V. paradoxus, this bacterium uses the AHLs as carbon and nitrogen sources (67). The effectiveness of oxidoreductases is usually lower than those of then AHL acylases and lactonases $(68,69)$, but there have been only a few studies of these molecules. AHL molecules can also be inactivated by different antibodies. For example, MAbs (monoclonal antibodies) inactivate QS-mediated pyocyanin production in $P$. aeruginosa (70). The QQ of AI-2 molecules is not as well known as in the case of AHLs. The enzyme Lsrk adds a phosphate group to the signal molecule, createing P-AI-2, with a decreased receptor binding ability. LsrK added externally to $S$. typhimurium, E. coli, and V. harvei cultures causes QQ in each case (71). DSF signals are used by many plant pathogenic bacteria, as in Xanthomonas species (causing black root) and X. fastidiosa, the causative agent of Pierce disease. Co-cultivation experiments have shown that numerous bacteria interfere with DSF signalling. Pseudomonas, Bacillus and Staphylococcus strains also have the carA and carB genes, responsible for the QQ activity (72). Co-infection with bacteria, harbouring high level of DSF degrading activity results in decreased pathogenicity in both black root and Pierce disease as well. The PQS-mediated QS of P. aeruginosa can be decreased by the enzyme Hod. A lower pathogenicity has been demonstrated in a lettuce leaf model (73). The AIPs can be inactivated by different kinds of antibodies. For example, Mabs, like AP4-24H11, decreases the production of virulence factors and increases biofilm production (which is down-regulated by QS) in S. aureus (74).

\subsubsection{Inhibition of signal detection}

The inhibition of signal detection is based on different QS signal analogues. These molecules can bind the receptor of the given QS molecule, but do not cause the same effect in gene expression. This competitive binding is a very good alternative for QQ. Analogues can exhibit 
different activities, e.g. no activity, pure antagonism, pure agonism, partial antagonism, partial agonism or synergistic agonism (75-77). Inhibition of signal receptors is found in many cases, including AHL, AIP, AI-2, AI-3, PQS and HHQ-based systems.

A wide range of AHL analogues have been tested, including thiolactones (78), lactams (79), urea (80) and triazolyldihydrofuranone (81) based analogues. Many AHL receptors are known, e.g. QscR, LasR, TraR and LuxR. The Mattmann laboratory has tested a plethora of analogues and found molecules which cause antagonism on these receptors (82). The most interesting molecule is S7, which is active against all 4 investigated AHL receptors (Fig 11).

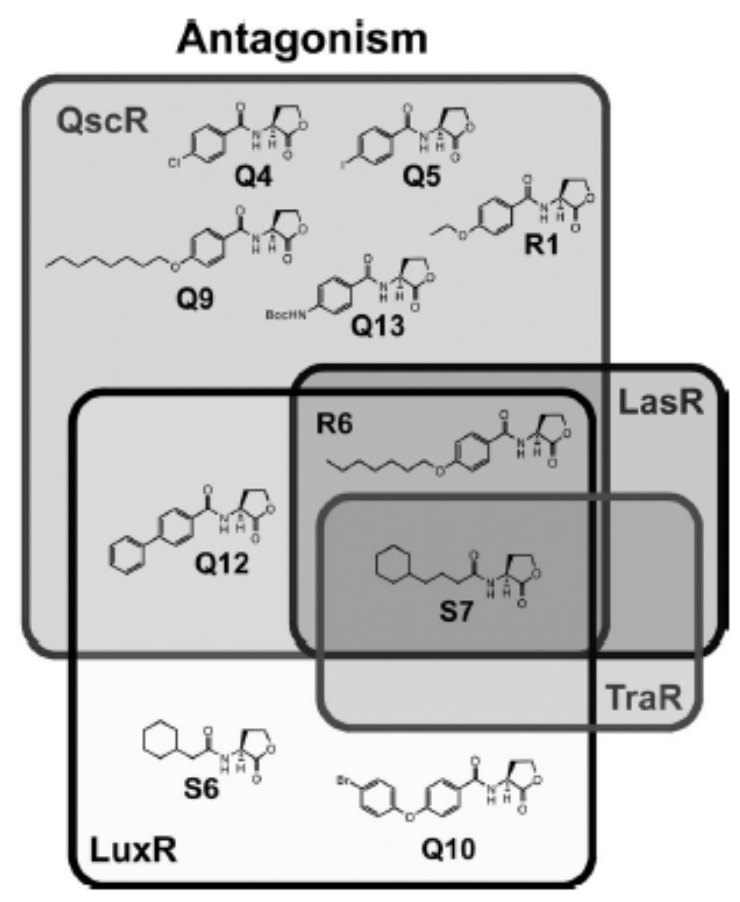

Figure 11.

Different AHL receptor antagonists (82)

Different halogenated furanones are good inhibitors of both AHL and AI-2 receptors (83-85). Besides brominated and chlorinated furanones, numerous AI-2 receptor inhibitors are known. Pyrogallol is probably the best inhibitor, but different DPD analogues also have a great future (86-88).

The usage of peptide-type AI analogues is a good alternative to quench the QS system of Gram-positive bacteria. The most marked evidence of this is found in S. aureus. At least 4 types of S. aureus exist as concerns their AIPs. The AgrC receptor responds to its own AIP, but binds the signal molecules from the other groups without modifying the gene expression. This competitive binding ensures the stability of the first colonizing strain (89). One type of 
AIP of $S$. aureus can block the QS of the other strains. trAIP-II is a very good inhibitor for all 4 strains (90). Naturally, the AIP antagonists based on Gram-positive QS inhibition are not restricted to $S$. aureus, AIP analogues synthesized against other species as well e.g. $S$. pneumoniae (91).

\subsection{Biofilms and QS}

Biofilms are complex bacterial communities embedded in extracellular polymeric substances (EPSs). This multicellular lifestyle provides numerous benefits for the bacteria. The EPS matrix protects the bacteria from chemicals, the immune system, predation, desiccation, oxidizing molecules and other damaging agents (92). Division of labour is also evident in multispecies biofilm. In spite of the developed aqueduct structures, there are spaces where oxygen, water and nutrient availability is relatively low. Here, metabolically inactive cells exist, which can recolonize the biofilm after antibacterial attack. The biofilm also prove a good place for genetic information exchange. The EPS holds the microbes close proximity to each other, helping the bacterial-bacterial interactions. The persistence of drug resistance markers and other virulence factors is therefore promoted. Because of these beneficial features, biofilms cause most problematic bacterial infections. The antibiotic resistance inside the biofilm is nearly 1000 -fold higher, than in planktonic bacteria. Biofilms have the greatest significance in the following cases: catheter and other device-associated infections $(93,94)$, urinary tract infections (95), periodontitis (96) and upper respiratory tract infections $(97,98)$. QS is essential for normal biofilm development in numerous pathogens. The life of a biofilm can be categorized by 3 stages. The first is the attachment, which is followed by the maturation and finally the dispersion. There are examples of the influence of QS in all 3 stages. In the attachment phase, probably the most interesting examples are found in S. aureus and Helicobacter pylori (H. pylori). The AgrC/AgrA QS system of S. aureus regulates the level of surface adhesins, which influence the attachment to the host (99). The luxS homologue of $H$. pylori is also implicated in the biofilm attachment. The luxS mutants adhere twice as effectively (100). There is also considerable evidence of the influence of QSmediated processes in biofilm maturation: in Serratia liquefaciens (101), Burkholderia cepacia (102), Aeromonas hydrophila (103), Streptococcus mutans (104). There are also examples of QS mediation of the dispersion; for example, a plant pathogen bacterium, $X$. campestris, uses DSF signals to regulate the biofilm dispersal (105). 


\subsection{Aims}

Antibiotic-resistant and pathogenic bacteria often cause life-threatening infections. To overcome these infections, we wished to know the different mechanisms of various bacterial species and host interactions. In the present thesis, my attention focused on in vitro models of interbacterial communication called QS, i.e. the communication system dependent on the size of the population in an in vitro model basically related to antibiotic resistance and biofilm formation. The main points studied in the thesis are as follows:

1. First of all, the antibacterial effects of essential oils and other compounds were studied, before studies of the effects of QS signal transmission.

2. As known inhibitors of $A B C$ transporters, the phenothiazines were included in structureactivity studies of QS.

3. The structure-activity-dependent effects of trifluoromethyl ketone (TF) proton pump inhibitors on QS signal transmission were investigated in vitro.

4 The interaction with some QS inhibitors was investigated with AHLs.

5. The effect of interference between bacterial population on the QS signal were investigated by using different bacterial strains, including clinical isolates and laboratory strains.

6. The EZF 10-17 grapevine isolate, and its AHL profile were identified.

\section{Materials and Methods}

2.1. Tricyclic compounds used: promethazine (Pipolphen, EGIS, Hungary), amitriptyline (Teperin, EGIS, Hungary), acridine orange (AO) (Reanal, Hungary), imipramine (Melipramin, EGIS, Hungary), desipramine, chlorprothixene (Truxal, Lundbeck, Denmark), promazine, diethazine (Parkazin, Rhone-Poulenc, France) and desertomycin. Stock solutions of these tricyclic compounds were prepared in distilled water at $25.0 \mathrm{mg} / \mathrm{ml}$ before use. Thioridazine (TZ) (Sigma, Madrid, Spain) was used as positive control for the efflux pump inhibition. 


\subsection{Other chemicals}

5-Fluorouracil (5-FU) (Sigma-Aldrich, Budapest, Hungary)

Iodine deoxyuridine (IDU)

Ethidium bromide (EB) (Sigma, Madrid, Spain)

Dimethyl sulfoxide (DMSO)

N-Hexanoyl-DL-homoserine lactone (SIGMA, Budapest).

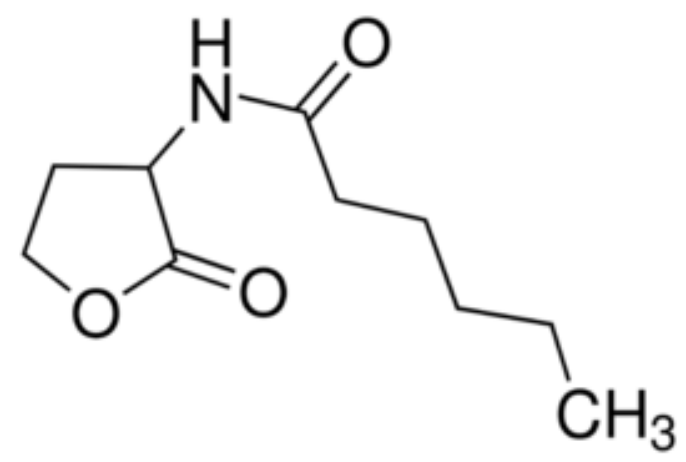

Figure 12.

The N-hexanoil-DL-homoserine lactone molecule (106)

2.3. Trifluoromethyl ketones used: Eleven TFs $(1-9,11$ and 12) were synthetized by reaction of the corresponding 2-methylbenzazoles with trifluoroacetic or chlorodifluoroacetic anhydride (107). Compound 10 was prepared by treatment of 2-lithiomethylbenzoxazole with ethyl acetate $(108,109)$. $N$-Hexanoyl-DL-homoserine lactone was purchased from Sigma (Budapest, Hungary). TFs were dissolved in, DMSO.The structures of the TFs is presented in Table 1. 
Table 1.

Trifluoromethyl ketones investigated in the study<smiles></smiles>

\begin{tabular}{|c|c|c|c|c|}
\hline & $\mathrm{R}^{1}$ & $\mathrm{R}^{2}$ & $\mathrm{R}^{3}$ & $X$ \\
\hline 1 & $\mathrm{H}$ & $\mathrm{H}$ & $\mathrm{CF}_{3}$ & 0 \\
\hline 2 & $\mathrm{Cl}$ & $\mathrm{H}$ & $\mathrm{CF}_{3}$ & O \\
\hline 3 & $\mathrm{~F}$ & $\mathrm{H}$ & $\mathrm{CF}_{3}$ & $\mathrm{O}$ \\
\hline 4 & $\mathrm{CH}_{3}$ & $\mathrm{H}$ & $\mathrm{CF}_{3}$ & O \\
\hline 5 & $\mathrm{CH}_{3} \mathrm{O}$ & $\mathrm{H}$ & $\mathrm{CF}_{3}$ & 0 \\
\hline 6 & $\mathrm{Ph}$ & $\mathrm{H}$ & $\mathrm{CF}_{3}$ & O \\
\hline 7 & $\mathrm{COOC}_{2} \mathrm{H}_{5}$ & $\mathrm{H}$ & $\mathrm{CF}_{3}$ & O \\
\hline 8 & $\mathrm{H}$ & $\mathrm{COOC}_{2} \mathrm{H}_{5}$ & $\mathrm{CF}_{3}$ & $\mathrm{O}$ \\
\hline 9 & $\mathrm{H}$ & $\mathrm{H}$ & $\mathrm{CClF}_{2}$ & O \\
\hline 10 & $\mathrm{H}$ & $\mathrm{H}$ & $\mathrm{CH}_{3}$ & 0 \\
\hline 11 & $\mathrm{H}$ & $\mathrm{H}$ & $\mathrm{CF}_{3}$ & $\mathrm{NH}$ \\
\hline 12 & $\mathrm{H}$ & $\mathrm{H}$ & $\mathrm{CF}_{3}$ & $S$ \\
\hline
\end{tabular}

2.4. Essential oils used: Rose (Rosa damascena L., Rosaceae), lavender (Lavandula angustifolia L., Labiatae), chamomile (Matricaria recutica L., Asteraceae), orange (Citrus sinensis L., Myrtaceae), eucalyptus (Eucalyptus globulus L.,Myrtaceae), geranium (Geranium robertianum L., Geraniaceae), juniper (Juniperus communis L., Cupressaceae), citrus (Citrus lemon) and rosemary oils (Rosmarinus officinalis L., Lamiaceae) were purchased from Phoenix Pharma Ltd. (Hungary). The oils were either used directly (concentrated) or dissolved in DMSO to yield a dilution of $10 \%(\mathrm{v} / \mathrm{v})$. The stock solution was either used directly or further diluted with 10\% DMSO. Both AO and 5-FU were dissolved in distilled water.

\subsection{Bacterial strains:}

C. violaceum 026 (CV026) served as QS sensor. C. violaceum is a common bacterium which lives in soil and water. When $C$. violaceum reaches a high cell density, it produces a purple pigment, violacein (110). The CV026 sensor strain is a Tn5 mutant which alone cannot synthesize AHLs; it produces the purple pigment only in the presence of externally added inducers (111). This strain has been used to detect a wide range of short-chain AHLs or QS inhibitors (112-114). 
EZF 10-17 was isolated from a grapevine crown gall tumour. This strain induced pigment production by CV026 and proved to be efficient for the study of QS interactions (115). Enterobacter cloaceae (E. cloaceae) 31298; a clinical wound isolate, was used as AHL producer.

E. coli wild-type AG100 [argE3 thi-1 rpsL xyl mtl (gal-uvrB) supE44] was employed for determination of the effects of TFs on the activity of the intrinsic efflux pump of this organism (116).

P. aureginosa 49010 was clinical strains isolated from the human trachea.

Strains used in the interference of QS amongst microbial species experients:

Fungi: Candida krusei, Candida tropicalis and C. albicans

Bacteria: Achromobacter xylosoxidans 40502, Acinetobacter baumannii 32703, A. baumanni 42701, Bacillus cereus, Bacillus subtilis, Bacillus clausii, Bacillus megaterium PV 361, Bacillus megaterium MS 941, Bacillus megaterium 216, Staphylococcus epidermidis, $S$. aureus and E. coli strains were isolated from extraintestinal infections numbered 5536, 10902, 10904, 11925, 14525, 14584, 18596, 19579, 19672, 24310, 24409, 24442, 33444, 36446 and 40312.

\subsection{Media}

LB (Luria-Bertani) medium: containing yeast extract $5 \mathrm{~g} / \mathrm{l}$, trypton $10 \mathrm{~g} / \mathrm{l}$ and $\mathrm{NaCl} 10 \mathrm{~g} / \mathrm{l}$ Modified LB agar (LB*) containing yeast extract $5 \mathrm{~g}$, trypton $10 \mathrm{~g}, \mathrm{NaCl} 10 \mathrm{~g}, \mathrm{~K}_{2} \mathrm{HPO}_{4} 1 \mathrm{~g}$, $\mathrm{MgSO}_{4} .7 \mathrm{H}_{2} \mathrm{O} 0.3 \mathrm{~g}$ and FeNaEDTA $36 \mathrm{mg}$ in 1.01 of distilled water, Potato dextrose agar (PDA), Mueller-Hinton broth (MHB) and Mueller-Hinton agar (MHA) purchased in powder form from Sigma (Madrid, Spain), Blood agar, complemented with sheep blood

\section{Methods}

2.7. QS tests: LB* was used for the experiments. The sensor strain CV026 and the AHL producer strains EZF 10-17, E. cloaceae 31298 or P. aureginosa 49010 were inoculated as parallel lines and incubated at room temperature $\left(20{ }^{\circ} \mathrm{C}\right)$ for $24-48 \mathrm{~h}$. QS inhibition was monitored by the agar diffusion method. Filter paper discs $(7.0 \mathrm{~mm}$ in diameter, Whatmann $3 \mathrm{MM}$ ) were impregnated with $10 \mu 1$ of stock solutions of the compounds in distilled water or DMSO. The discs were placed between the parallel lines of sensor and AHL producer strains on the surface of nutrient agar. The plates were incubated at room temperature for a further 24-48 $\mathrm{h}$ and the interactions between the strains and compounds were evaluated as concerns 
the reduction in size of the zone of pigment production and the zone of growth inhibition of the affected strains, in mm. 5-FU and AO was applied as positive controls (117).

\subsection{QS interference tests}

QS modification experiments with $E$. coli strains: Suspensions of each E. coli strain were separately mixed with molten LB* agar medium. One hour later, parallel lines of the pair of CV026 sensor and Ezf 10-17, and E. cloaceae 31298 AHL-producing strains were inoculated, and incubation was performed at room temperature $\left(20^{\circ} \mathrm{C}\right)$ for $24-48 \mathrm{~h}$.

QS inhibition of bacterial strains: Each investigated strain was inoculated at right angles through the parallel lines of the pair of CV026 sensor and EZF 10-17 AHL-producing strains, and then incubated at room temperature for a further $24-48 \mathrm{~h}$. LB* medum was used, for Candida, Acinetobacter, Achromobacter, Bacillus, E. coli and Staphylococcus species, etc. For Streptococcus species, blood agar was used, and the plates were pre-incubated for $5 \mathrm{~h}$ at $37^{\circ} \mathrm{C}$, and further incubation being continued at room temperature. QS inhibition was revealed as a decreased level of violacein production by CV026.

\subsection{Evaluation of complex formation between $\mathrm{N}$-hexanoyl-DL-homoserine lactone and}

QS inhibitors: Biological method: $1 \mu 1$ of a solution of 5, 10 or $25 \mathrm{ng}$ of AHL was mixed with $10 \mu \mathrm{l}$ of stock solution $(25 \mathrm{mg} / \mathrm{ml})$ of the potential QS inhibitor. Filter paper discs (7.0 $\mathrm{mm}$ in diameter, Whatmann $3 \mathrm{MM}$ ) were impregnated with $11 \mu \mathrm{l}$ of the mixture of QS inhibitor and AHL solution. The discs were placed upon the inoculation line of the CV026 sensor strain on the surface of nutrient agar medium. The plates were incubated at room temperature $\left(18-22^{\circ} \mathrm{C}\right)$ for a further $24-48 \mathrm{~h}$, and the interactions between the AHL and the tricyclic compounds were evaluated in terms of the reduction in diameter of pigment production, and the reduced colour intensity.

\subsection{Taxonomic identification of EZF 10-17 and analysis of its AHL production} The V3 region of 16S rDNA from EZF 10-17 was amplified by using the forward primer (5'ACTCCTACGGGAGGCAGCAG-3') and reverse primer (5'-ATTACCGCGGCTGCTGG3') and sequenced. Sequence data were compared and analysed by BLAST to the published 16S V3 sequences available in the database. The AHLs from the liquid culture of EZF 10-17 were extracted and concentrated by using acidified ethyl acetate liquid-liquid extraction. The 
purified AHLs were analysed by using thin-layer chromatography (TLC) overlaid with the $C$. violaceum $\mathrm{CV} 026$ biosensor strain.

2.11. Minimum inhibitory concentration (MIC) of each TF on CV026 and E. coli AG100. The MICs of TFs were determined by the broth dilution method according to the Clinical and Laboratory Standards Institute (CLSI) guidelines (118).

\subsection{Assessment of the effects of each TF on the activities of the efflux pump systems of}

CV026 and E. coli AG100. The activities of the TFs on the real-time accumulation of EB were assessed by the automated EB method previously described in detail (119), using the Rotor-Gene $3000^{\mathrm{TM}}$ thermocycler with real-time analysis software (Corbett Research, Sydney, NSW, Australia). Briefly, E. coli AG100 was cultured in MHB medium until the culture reached an optical density (OD) of 0.6 at $600 \mathrm{~nm}$. The culture was then centrifuged at $13,000 \mathrm{rpm}$ for $3 \mathrm{~min}$, the pellets were resuspended in phosphate-buffered saline (PBS; $\mathrm{pH}$ 7.4), with a final concentration of $0.4 \%$ glucose, and the OD was adjusted to 0.6 at $600 \mathrm{~nm}$. Aliquots of $45 \mu \mathrm{l}$ of the cell suspension were distributed to $0.2 \mathrm{ml}$ tubes. The TFs were individually added at concentrations equal to half their MIC against the strain in $5 \mu$ l volumes of their stock solutions, and finally $45 \mu \mathrm{l}$ of EB to yield a final concentration of $1 \mathrm{mg} / \mathrm{l}$ (Sigma-Aldrich Química SA, Madrid, Spain) in PBS, with or without glucose, was added. The selection of the concentration of each TF at half its MIC was due to the empirical fact that at this concentration there is no significant effect on the viability of the organism $(119,120)$. It is also important to note that prior to the experiments described, the maximum concentration of EB which was within the capacity of the bacterium to extrude was determined at least three times. For the wild-type E. coli AG100 reference and the CV026 strains employed in the study, these concentrations of EB were determined to be 1 and 0.5 $\mathrm{mg} / \mathrm{l}$, respectively $(116,119,120)$. The tubes were placed into a Rotor-Gene $3000^{\mathrm{TM}}$ thermocycler and the fluorescence was monitored on a real-time basis. From the real-time data, the activity of the TF, i.e. the relative final fluorescence (RFF) of the last time point (at $30 \mathrm{~min}$ ) of the EB accumulation assay was calculated according to the formula:

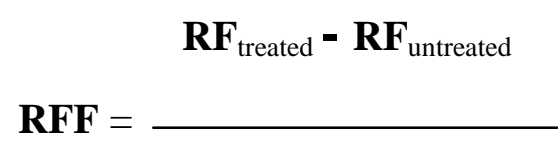

$\mathbf{R F}_{\text {untreated }}$ 
where $\mathbf{R F}_{\text {treated }}$ is the relative fluorescence at the last time point of the EB retention curve in the presence of an inhibitor, and $\mathbf{R F}_{\text {untreated }}$ is the relative fluorescence at the last time point of the EB retention curve of the untreated control. The greater the difference between $\mathbf{R} \mathbf{F}_{\text {treated }}$ and

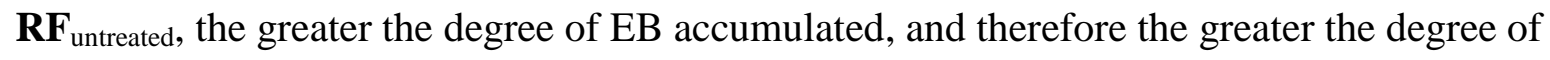
inhibition of the efflux pump system of the bacterium promoted by the agent at that concentration.

The RFF was then divided by the concentration of the TF that corresponded to half its MIC. This yielded a measure of the effect of each TF at a milligram level (specific activity) and therefore afforded comparison of each TF for activity against the efflux pump systems of the CV026 and E. coli AG100 strains. The experiments were repeated three times and the specific activity values presented are the averages of three independent assays. This method of analysis has been described previously (121). TZ an efflux pump inhibitor (122), served as a positive control.

\section{Results}

\subsection{QS inhibition of essential oils}

The agar diffusion method provides a convenient and semiquantitative method with which to assess antibacterial activities and QS signal production in the presence of essential oils. Using this method, we tested 9 essential oils compared to the positive controls of AO and 5-FU. Most of these oils are known as inhibitors of bacterial growth (123). Our data demonstrate that several plant-derived essential oils not only inhibit bacterial growth, but also block QS regulation processes.

As evident from Fig. 13, DMSO did not affect bacterial growth or AHL-induced violacein production. As demonstrated by Fig. 14, the positive controls 5-FU and AO produced the anticipated inhibition of QS. However, the inhibitory activity of 5-FU was considerably greater than that of $\mathrm{AO}$.

The use of discs impregnated with DMSO containing various essential oils afforded an understanding of which oils inhibited the QS response of CV026 to AHL released by the bacteria employed in this study. As examples, although geranium oil was most effective as an inhibitor of the QS response of CV026 (Fig. 15a) following induction by the AHL-producing strains E. cloaceae 31298 and EZF 10-17, rose oil also displayed significant inhibitory activity on QS responses (Fig. 15b). Rose, lavender and rosemary oils also inhibited the 
colour development to varying degrees (Table 2). Eucalyptus oil inhibited violacein production only after induction with E. cloaceae 31298, while citrus oil reduced the colour formation only in the CV026 + EZF 10-17 combination. As expected, the oils also inhibited bacterial growth to variable degrees. The other tested essential oils too exhibited weak antibacterial activity on CV026 but the growth of the AHL-producing bacteria was not affected. QS was moderately inhibited by lavender, eucalyptus and citrus oils, while chamomile, orange and juniper oils were ineffective (Table 2).

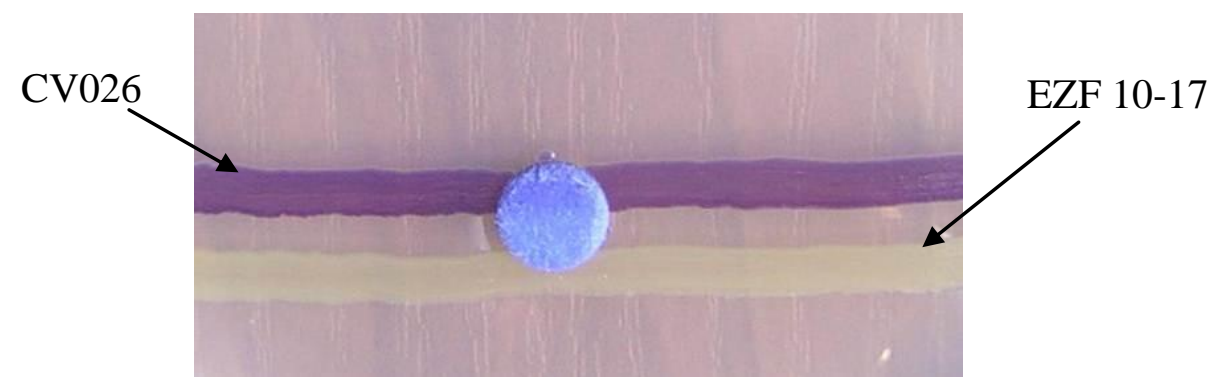

Figure 13.

Negative control: DMSO did not affect colour production by the QS sensor C. violaceum CV026 in response to an AHL-producing bacterium.

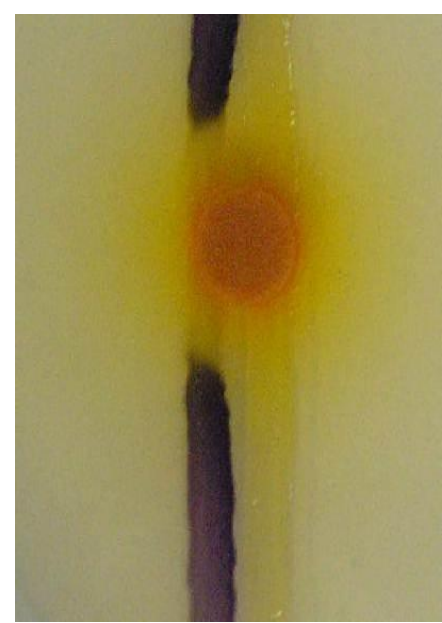

A

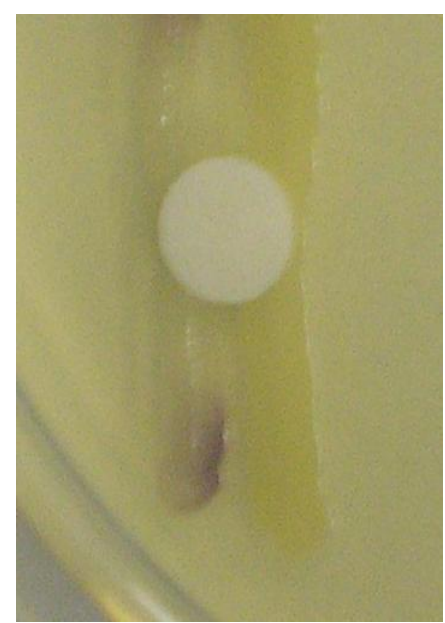

B

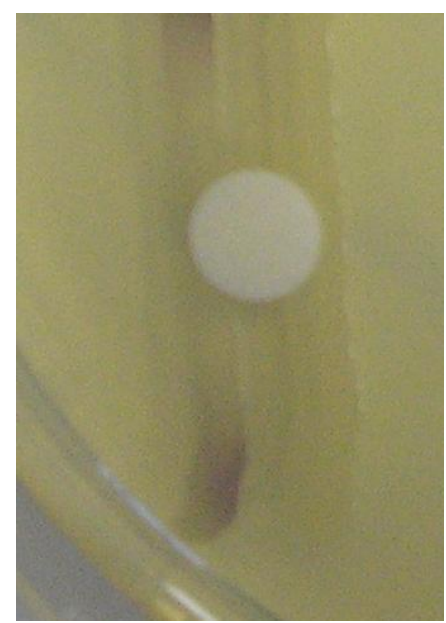

C

Figure 14.

Positive controls: Disc impregnated with AO (left) or 5-FU (middle, right) inhibited the production of colour by $C$. violaceum $\mathrm{CV} 026$ (left lines) in response to the AHL-producing bacterium EZF 10-17 (Fig. 2a,b) and E. cloaceae 31298 (Fig. 2c). 


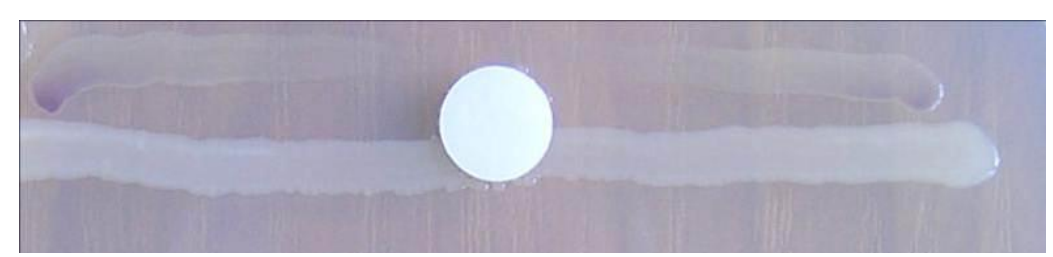

Figure 15a.

Effect of geranium oil on QS. The disc contained $10 \mu 1$ geranium oil.

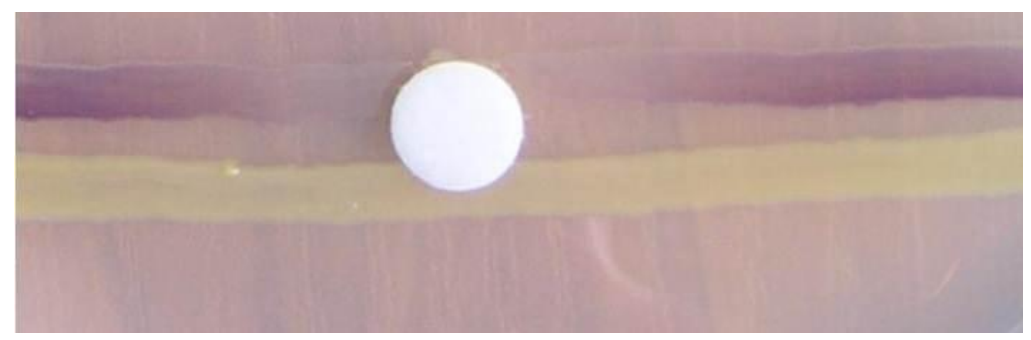

Figure 15b.

Effect of rose oil on QS. The disc contained $10 \mu 1$ rose oil.

Table 2. Effects of tested essential oils on QS signal production between C. violaceum CV026 as sensor, and E. cloaceae 31298 and EZF 10-17 as producer strains after a $48 \mathrm{~h}$ incubation.

\begin{tabular}{|l|l|l|l|l|}
\hline \multirow{2}{*}{ Essential oils } & \multicolumn{2}{|c|}{$10 \%$ oil } & \multicolumn{2}{c|}{$100 \%$ oil } \\
\cline { 2 - 5 } & $\begin{array}{l}\text { CV026 }+ \\
\text { E. cloaceae } \\
31298\end{array}$ & $\begin{array}{l}\text { CV026 }+ \\
\text { EZF 10-17 }\end{array}$ & $\begin{array}{l}\text { CV026 }+ \\
\text { E. cloaceae } \\
31298\end{array}$ & $\begin{array}{l}\text { CV026 + } \\
\text { EZF 10-17 }\end{array}$ \\
\hline Rose & $15-20$ & 10 & 18 & 20 \\
\hline Lavender & 0 & 5 & 10 & 15 \\
\hline Chamomile & 0 & 0 & 0 & 0 \\
\hline Geranium & 0 & 3 & 13 & 15 \\
\hline Eucalyptus & 0 & 3 & 6 & 0 \\
\hline Juniper & 0 & 0 & 0 & 16 \\
\hline Citrus & 0 & 2.5 & 0 & 0 \\
\hline Orange & 0 & 0 & 0 & 18 \\
\hline Rosemary & 0 & 3 & 18 & 0 \\
\hline
\end{tabular}

The numbers in the Table indicate the sizes of the inhibition zones in $\mathrm{mm}$ 


\subsection{QS inhibition of tricyclic compounds}

The agar diffusion method provided an opportunity to investigate the potential inhibition of tricyclic compounds on QS between the QS sensor C. violaceum and 3 AHL-producing bacteria. For control experiments, EZF 10-17 adjacent to the QS sensor CV026 cultured in the presence of a water-containing disc resulted in the purple colouration of the swabbed sensor, an indication of a positive response to the presence of AHLs produced by EZF 10-17. To demonstrate that the colouration of the sensor strain is prevented by a known inhibitor of the QS response, 5-FU and AO were used as positive controls. Since the phenothiazines exert antimicrobial activity against $E$. coli (124), the inhibition of violacein production as QS signal on the growth of inoculated bacteria was measurable only at subinhibitory concentrations. Consequently, the production of AHL as a QS mediator was evaluated below the MICs of the phenothiazines against the AHL-producing bacteria.

The amount of each phenothiazine placed onto the disc was chosen so that it did not produce any antimicrobial effect against the given bacterium (less than one-half of the MIC). In summary, amitriptyline, desipramine, imipramine and promethazine inhibited the production of the purple colour by the sensor CV026 strain. Although the concentration of each phenothiazine was identical, the degree of inhibition varied as the distance between the disc and the margins of the diameter of the produced colouration. Table 3 shows the antibacterial effects of the phenothiazines: the diameters of the growth inhibitory zones are indicated in $\mathrm{mm}$.

Table 3.

Investigation of antibacterial effects of tricyclic compounds with the agar diffusion method.

\begin{tabular}{|c|c|c|c|c|c|c|}
\hline \multirow[b]{2}{*}{$\begin{array}{l}\text { Tricyclic } \\
\text { compounds }\end{array}$} & \multicolumn{6}{|c|}{ Growth inhibition zones in $\mathrm{mm}$} \\
\hline & $\begin{array}{c}E Z F 10- \\
17\end{array}$ & $\begin{array}{c}E . \\
\text { cloaceae } \\
31298\end{array}$ & $\begin{array}{c}P . \\
\text { aeruginosa } \\
49010\end{array}$ & $\begin{array}{c}C V 026 \\
(+E Z F \\
10-17)\end{array}$ & $\begin{array}{c}\text { CV026 } \\
(+ \text { E. } \\
\text { cloaceae } \\
\text { 31298) }\end{array}$ & $\begin{array}{c}\text { CV026 } \\
(+P . \\
\text { aeruginosa } \\
49010)\end{array}$ \\
\hline $\mathrm{AO}$ & - & - & - & - & - & - \\
\hline Amitriptyline & 8 & - & - & 9 & 10 & 12 \\
\hline Desipramine & 9 & 7 & - & 11 & 16 & 9 \\
\hline Imipramine & - & - & - & 9 & 9 & 7 \\
\hline Diethazine & 7 & - & - & 9 & 7 & 8 \\
\hline Promazine & 8 & - & - & 10 & 12 & 15 \\
\hline Promethazine & 9 & 7 & - & 11 & 15 & 10 \\
\hline Chlorprothixene & - & - & - & 7 & 7 & 7 \\
\hline
\end{tabular}

$10 \mu 1$ of a $25 \mathrm{mg} / \mathrm{ml}$ solution was added to the filter paper discs 
To study the effects of phenothiazines and structurally related compounds on QS, the tricyclic compounds were examined in a concentration below the growth inhibitory doses. The inhibition of QS signal transmission was measured as described in the Methods section. The production of colourless zones by the phenothiazine compounds impregnated into the filter paper discs was measured around CV026, in response to the inhibited AHLs produced by EZF 10-17, E. cloaceae and P.aeruginosa. As shown in Table 4, the degree of inhibition of purple colour formation by CV026 in response to the AHLs produced by the various bacteria differed, indicating that the effectivities of the tricyclics differed as regards the QS response to the sensor CV026.

Table 4.

Inhibitory effects of tricyclic compounds on QS signal transmission.

\begin{tabular}{|c|c|c|c|}
\hline \multirow{2}{*}{$\begin{array}{c}\text { Tricyclic } \\
\text { compounds }\end{array}$} & \multicolumn{3}{|c|}{ QS inhibition zone in mm } \\
\cline { 2 - 4 } & EZF10-17 & E. c. 31298 & P. a. 49010 \\
\hline AO & 14 & 12 & 14 \\
\hline Amitriptyline & 64 & 30 & 60 \\
\hline Desipramine & 26 & 26 & - \\
\hline Imipramine & 15 & 12 & - \\
\hline Diethazine & 18 & 12 & 20 \\
\hline Promazine & 13 & 13 & 15 \\
\hline Promethazine & 26 & 20 & - \\
\hline Chlorprothixene & - & - & . \\
\hline
\end{tabular}

$10 \mu \mathrm{l}$ of $25 \mathrm{mg} / \mathrm{ml}$ stock solution was impregnated into the filter paper discs ( $25 \mu \mathrm{g} / \mathrm{disc})$ and the colourless zone around the $C$. violaceum was measured after incubation for 24-36 $\mathrm{h}$ at room temperature.

The mechanism of QS inhibition was studied by measuring the effects of the direct interactions between the AHL and QS inhibitors on violacein production in the bioassay. The most effective inhibitors were imipramine, promethazine, desipramine and amitriptyline, which in high concentration inactivated the AHL and probably formed micellar complexes. The activities of the complexes between AHL and its inhibitors were measured in AHLspecific chromogenic tests. The biological activities of the AHL complexes were apparently reduced by complex formation, compared with the uncomplexed control AHL (Table 5). 
Table 5.

The effects of QS inhihibitors on N-hexanoyl-DL-homoserine lactone (C6 HSL)-mediated violacein production.

\begin{tabular}{|c|c|c|c|c|}
\hline Quantity of C6 HSL & $0 \mathrm{ng}$ & $5 \mathrm{ng}$ & $10 \mathrm{ng}$ & $25 \mathrm{ng}$ \\
\hline Tested compounds & \multicolumn{4}{|c|}{ Diameter of colouration in $\mathrm{mm}(18 \mathrm{~h})$} \\
\hline IDU $10 \mu \mathrm{g}$ & 0 & 15 & 25 & 30 \\
\hline Desertomycin $200 \mu \mathrm{g}$ & 0 & 22 & 25 & 30 \\
\hline $5-F U 30 \mu g$ & 0 & 29 & 35 & 35 \\
\hline Promethazine $250 \mu \mathrm{g}$ & 0 & 0 & 30 & 33 \\
\hline Desipramine $250 \mu \mathrm{g}$ & 0 & 0 & 28 & 32 \\
\hline Promazine $250 \mu \mathrm{g}$ & 0 & 0 & 30 & 32 \\
\hline Imipramine $250 \mu \mathrm{g}$ & 0 & 0 & 20 & 26 \\
\hline Amitriptyline $250 \mu \mathrm{g}$ & 0 & 0 & 25 & 30 \\
\hline C6 HSL control & 0 & 25 & 34 & 35 \\
\hline
\end{tabular}

\subsection{Identification of EZF 10-17 and its AHLs}

In our previous studies, the unidentified grapevine tumour isolate EZF 10-17 proved to be an inducer of violacein production by $C$. violaceum $\mathrm{CV} 026$. Thus, this pair of inducer/sensor strains was successfully used to study potential QS inhibitors $(115,125)$. To identify EZF 1017 , we sequenced the $\mathrm{V} 3$ region of the $16 \mathrm{~S}$ rDNA gene from its genome. On comparison of the sequence data with those found in the databases, this strain proved to be a member of the Sphingomonadaceae family.

The signal production of EZF 10-17 was analysed by TLC overlaid with C. violaceum CV026. As compared with the standard AHLs, EZF 10-17 produces a strong signal that comigrated with 3-oxo-C6 AHL. Additionally, weaker signals which seemed to be identical to C6 AHL, 3-oxo-C8 AHL and C8 AHL were also observed (Figure 16). These data support our earlier observations on the suitability of EZF 10-17 in QS assays with C. violaceum CV026 (125). 
Figure 16. Detection of AHLs from EZF 10-17.

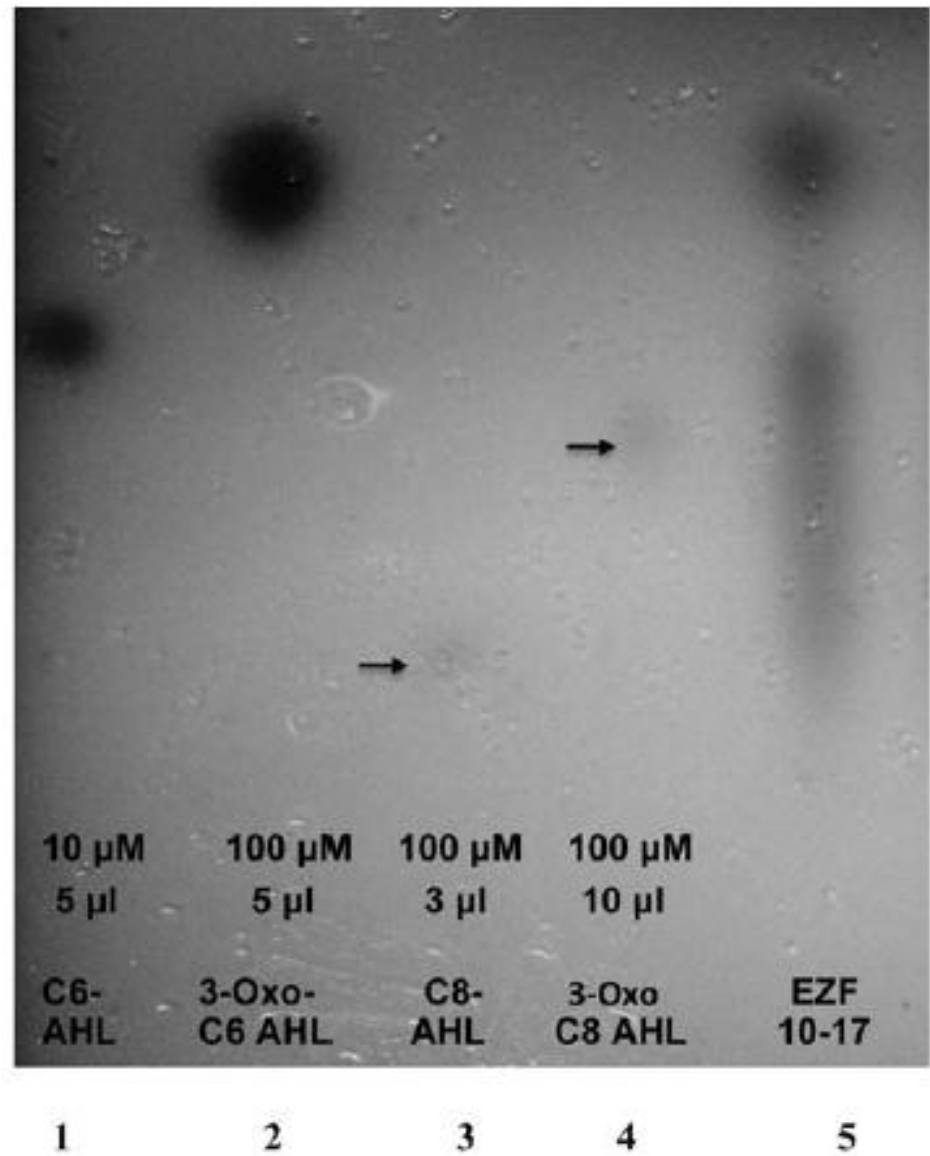

Legend. Pure AHLs (lanes 1-4) and purified AHL produced by EZF 10-17 (lane 5) isolated by TLC. The plate was overlaid with the responder CV026. The application of varying concentrations of pure AHLs provided standards of the degree of response (intensity of colour)

\subsection{QS and efflux pump inhibitor activity of TF compounds}

In order for an agent to be correctly evaluated for effects on a QS system whose intensity of colour is dependent upon the growth of the producer of the QS signal and the growth of the responding bacterium, the concentration of the agent that is to provide a meaningful interpretation must be one that does not affect the viability of either bacterium. As summarized in Table 6, various TFs displayed antimicrobial activities against the producer and responding bacteria. 
Table 6. Inhibitory effects of the TFs on QS and the growth of producing and QS sensor bacterial strains, after $24 \mathrm{~h}$ of incubation.

\begin{tabular}{|l|l|l|l|}
\hline TF & \multicolumn{2}{|c|}{ MIC $(\mu \mathrm{g} / \mathrm{ml})$} & $\begin{array}{l}\text { Extent of QS inhibition (zone } \\
\text { of discolouration) } \\
\text { at } 20 \mu \mathrm{g} / \text { disc }(\mathrm{mm})\end{array}$ \\
\hline $\mathbf{1}$ & 50 & 25 & 26 \\
\hline $\mathbf{2}$ & 12,5 & 25 & 28 \\
\hline $\mathbf{3}$ & 12,5 & 12,5 & 30 \\
\hline $\mathbf{4}$ & 50 & 50 & 20 \\
\hline $\mathbf{5}$ & 50 & 50 & 16 \\
\hline $\mathbf{6}$ & $>200$ & $>200$ & 0 \\
\hline $\mathbf{7}$ & $>200$ & $>200$ & 0 \\
\hline $\mathbf{8}$ & $>200$ & $>200$ & 0 \\
\hline $\mathbf{9}$ & 50 & 25 & 29 \\
\hline $\mathbf{1 0}$ & $>200$ & $>200$ & 0 \\
\hline $\mathbf{1 1}$ & $>200$ & $>200$ & 0 \\
\hline $\mathbf{1 2}$ & $>200$ & $>200$ & 0 \\
\hline
\end{tabular}

The extent of the colourless zone indicates the inhibitory effect of the given compound on QS signal transmission. (CV026: C. violaceum 026)

Consequently, the amounts of TFs selected for the evaluation of effects on the QS system were at or below those that had no effect on the growth of either species. Because of the limitations of space, the range of effects of the TFs on the QS system cannot be presented pictorially. Rather, the effects are illustrated in Figure 17 and Table 7. Briefly, TF 5 had the least inhibitory effect (a deep colour associated with the responder CV026) and TF 3 had the greatest inhibitory effects on the response of the CV026. The effect of the TFs on the QS system were clearly inhibitory. Whether the effect is due to the TF inhibiting the release of the QS signal or due to the inhibition of the response of the responding species cannot be distinguished from the above evaluation.

The direct effects of each TF on the QS response by CV026 were determined with the use of discs impregnated with combinations of a constant amount of the AHL and differing amounts of TF. The discs with TF alone did not produce the purple colour associated with CV026. The presence of pure AHL in the disc led to the production of the deep purple colour associated with CV026. The presence of the TF that inhibited the production of colour in the QS assay described, when in combination with the AHL, inhibited the production of the purple colour by the responding CV026. 


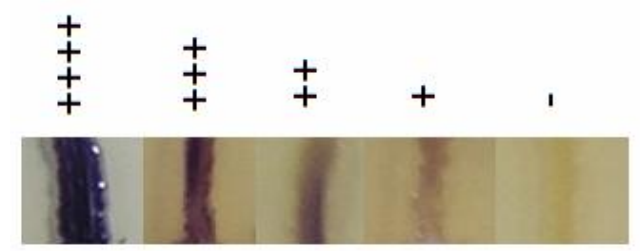

Figure 17.

The length and intensity of the purple colouration induced by $10 \mathrm{ng}$ AHL/disc on $C$. violaceum 026 , after a $24 \mathrm{~h}$ incubation in the presence of TFs applied at $20 \mu \mathrm{g} / \mathrm{disc}$. The effective inhibitors reduced the length and intensity of the purple colouration. The scale indicates an increasing intensity of colouration. A lower colour intensity means a greater inhibition of QS.

-, No colouration; +, white-purple; ++, pale-purple; +++, purple; ++++, dark-purple;

Table 7.

Effects of TFs on AHL-mediated QS.

\begin{tabular}{llll}
\hline $\begin{array}{l}\text { TF } \\
20 \mu \mathrm{g} / \mathrm{disc}\end{array}$ & $\begin{array}{l}\text { Intensity of } \\
\text { colouration } \\
(\mathrm{mm})\end{array}$ & $\begin{array}{l}\text { Length of } \\
\text { colouration } \\
(\mathrm{mm})\end{array}$ & $\begin{array}{l}\text { Growth } \\
\text { inhibition } \\
(\mathrm{mm})\end{array}$ \\
\hline $\mathbf{1}$ & +++ & 34 & 0 \\
$\mathbf{2}$ & + & 30 & 17 \\
$\mathbf{3}$ & + & 34 & 22 \\
$\mathbf{4}$ & +++ & 35 & 0 \\
$\mathbf{5}$ & +++ & 37 & 0 \\
$\mathbf{9}$ & + & 36 & 22 \\
AHL control & ++++ & 40 & 0 \\
\hline
\end{tabular}

Intensity scored as described in Figure 17

These results clearly show that the TF has a powerful inhibitory effect on the QS responding strain. However, the question of whether this same TF can inhibit the secretion of the QS signal by the producer species remains unanswered. The activity of each TF at half its MIC on the efflux pump system of the CV026 is exemplified by Figure 18 (126). 
A

TF1, TF4, TF5, TF9, TZ

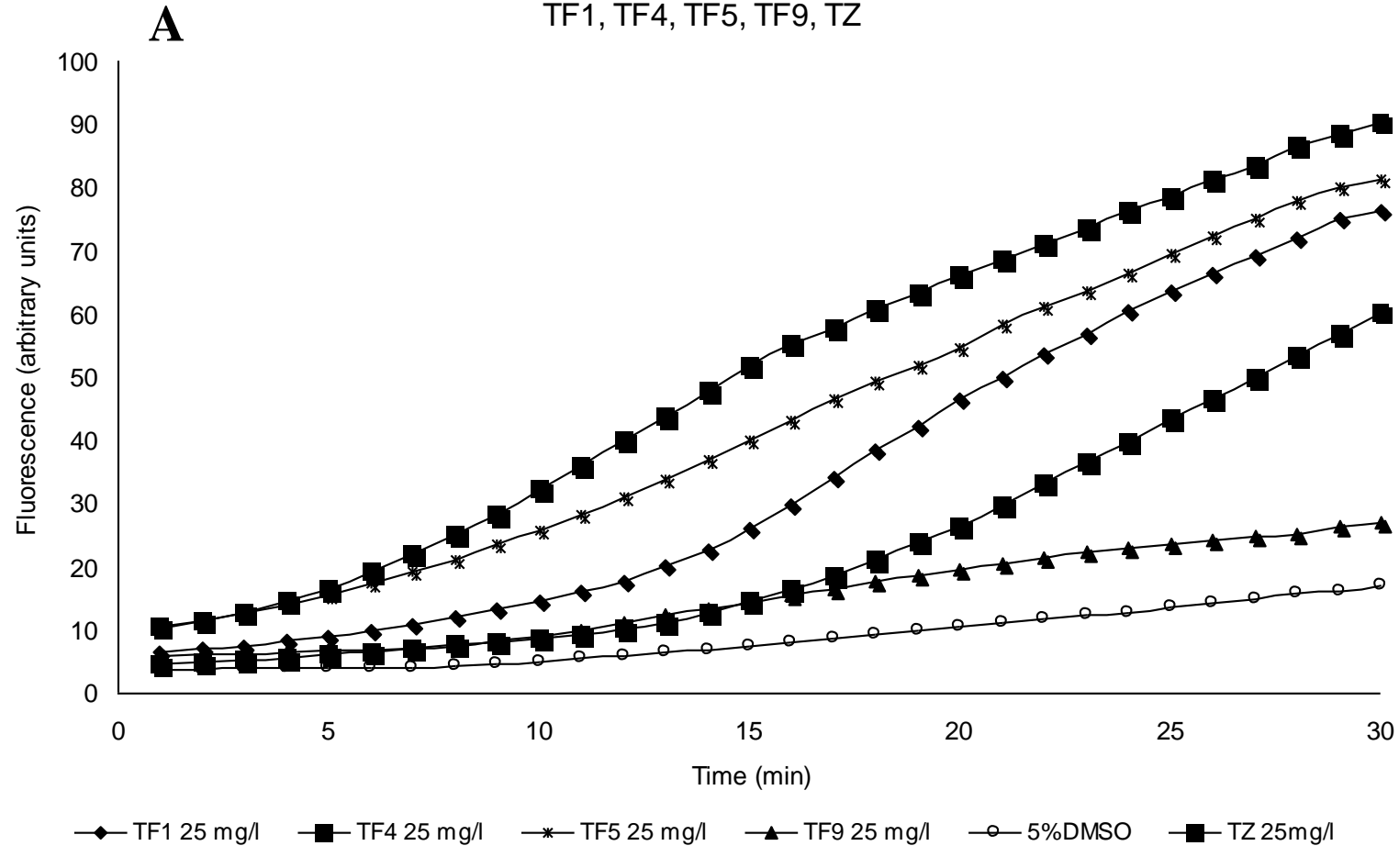

TF6, 7, 8, 10, 11, 12, TZ

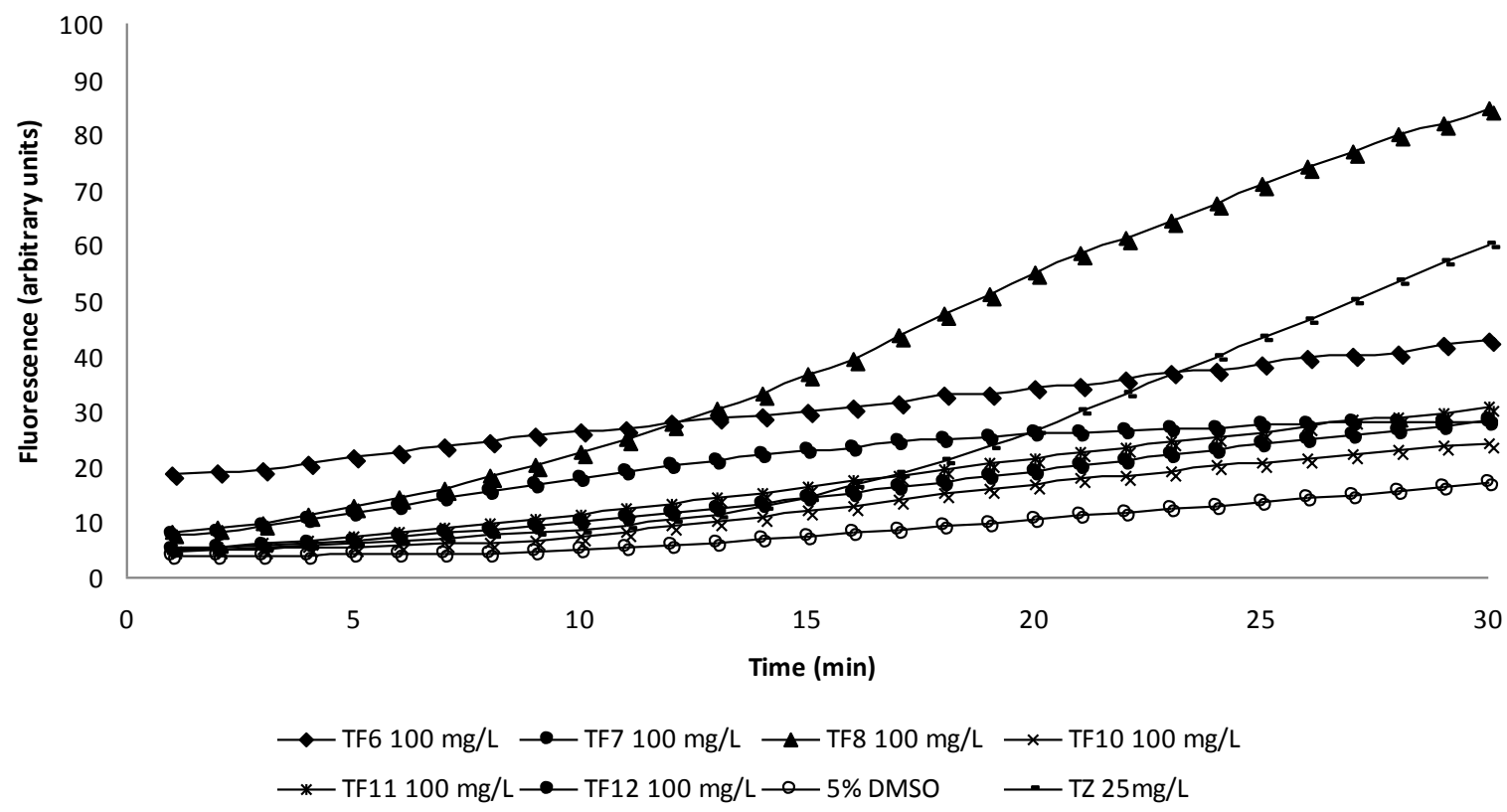

Figure 18. The effects of half the MIC of TFs 1, 4, 5, 9 (A), and 6, 7, 8, 10,11, 12 (B) as compared with the positive phenothiazine control TZ. 
The data presented by these Figures suggest that all of the TFs have activity against the efflux pump of CV026. However, as the concentrations of TFs used in the assay were half of their MICs, and the MICs of the TFs against the strain differed significantly, the activities shown in Figure $\mathbf{1 8}$ do not permit a comparison of the activities between the TFs. However, calculation of the specific activity of each TF by the formula for RFF presented in the Materials and Methods section affords a comparison, and these data are presented in Table 8.

Table 8. The related final fluorescence (RFF) and specific activity (SA) of each (TF) on the efflux pump system of CV026.

\begin{tabular}{|c|c|c|}
\hline \begin{tabular}{l|l} 
TF & \\
\end{tabular} & RFF & $\mathbf{S A}$ \\
\hline $1(25 \mathrm{mg} / \mathrm{l})$ & 4.20 & 1.68 \\
\hline $2(6.25 \mathrm{mg} / \mathrm{l})$ & 2.99 & 4.78 \\
\hline $3(6.25 \mathrm{mg} / \mathrm{l})$ & 2.21 & 3.53 \\
\hline $4(25 \mathrm{mg} / \mathrm{l})$ & 4.42 & 1.77 \\
\hline $5(25 \mathrm{mg} / \mathrm{l})$ & 5.10 & 2.04 \\
\hline $6(100 \mathrm{mg} / \mathrm{l})$ & 4.31 & 0.43 \\
\hline $7(100 \mathrm{mg} / \mathrm{l})$ & 0.92 & 0.09 \\
\hline $8(100 \mathrm{mg} / \mathrm{l})$ & 1.24 & 0.01 \\
\hline $9(25 \mathrm{mg} / \mathrm{l})$ & 3.97 & 1.59 \\
\hline $10(100 \mathrm{mg} / \mathrm{l})$ & 0.44 & 0.04 \\
\hline $11(100 \mathrm{mg} / \mathrm{l})$ & 0.73 & 0.07 \\
\hline $12(100 \mathrm{mg} / \mathrm{l})$ & 1.18 & 0.12 \\
\hline
\end{tabular}

Samples consisted of saline plus $1 \mathrm{mg} / \mathrm{l}$ of EB, $0.4 \%$ glucose, without or with half the MIC of the positive control and TFs. The fluorescence was assessed at $37^{\circ} \mathrm{C}$ for $30 \mathrm{~min}$. Data in bold indicate TFs that express very high inhibitory activity against the efflux pump system of

$$
\text { CV026. } \mathrm{SA}=\mathrm{RFF} /(0.5 \mathrm{MIC}) \text {. }
$$

Briefly, the activity of the positive control TZ was 1.02. On comparison of the activity of each TF relative to the positive control, TFs- 2 and 3 prove to exhibit the greatest activities against the efflux pump system of CV026; TFs-1, 4, 5 and 9 displayed significant activity; and TFs-7, $8,10,11$ and 12 had no activity. The facts that the TFs inhibited the response of an environmental strain to a QS signal and the same TFs inhibited the efflux pump of the environmental responding strain themselves did not support clinical interest in the TFs for possible use in the therapy of a bacterial infection. Therefore, in order to establish the necesarry support for the claim that the TFs do indeed have clinical value, the TFs were examined for activity against the efflux pump system of $E$. coli, a pathogenic bacterium. Since a large number of graphs would be needed to depict each effect, an example of the data obtained is presented in Figure 19 for TF-4. As evident from the Figure, the presence of TF-4 
promoted an increase of the fluorescence due to the accumulation of EB, whereas in the absence of the compound there was no significant increase of fluorescence (the curve is rather flat).

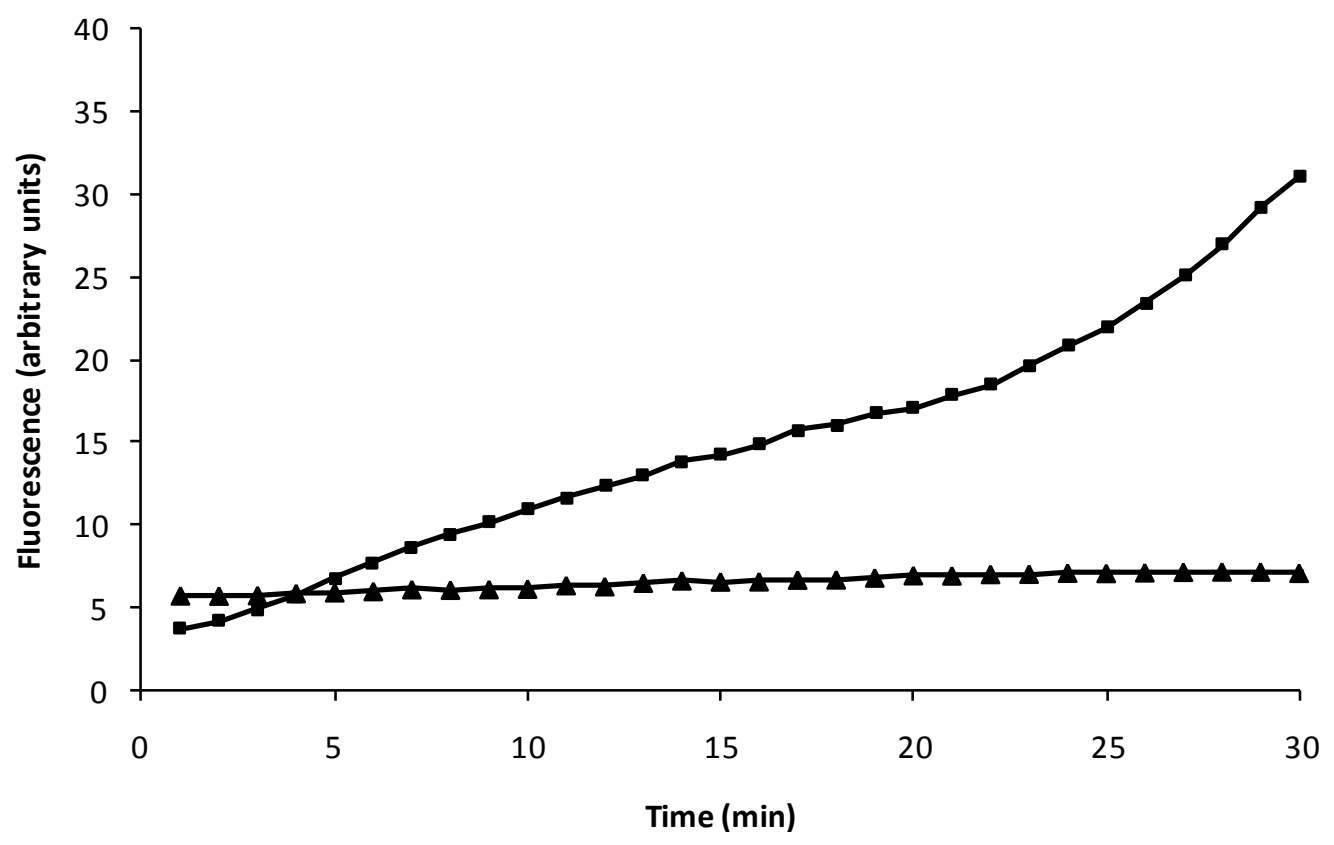

$\Delta$ E. coli AG100 control; E. coli AG100 and TF-4

Figure 19. The effect of TF-4 on the activity of the efflux pump system of $E$. coli AG100.

The concentration of TF-4 that corresponded to half the MIC was $30 \mathrm{mg} / \mathrm{l}$. Note that the control did not accumulate $\mathrm{EB}$ during the 30 min of the assay.

The effects of the TFs on the activity of the efflux pump are summarized in Table 9. This Table provides the concentrations of the positive control TZ and each of the TFs that corresponded to half their MIC. As noted in Table 9, TFs-2 and 3 exerted the highest activities against the efflux pump system of E. coli. TFs-1, 4, 5 and 9 were also very active since their inhibitory activities exceeded that of TZ, the efflux pump inhibitor that served as positive control. 
Table 9. The effects of (TFs) on the efflux pump system of E. coli AG 100.

\begin{tabular}{|l|c|c|}
\hline \multicolumn{1}{|c|}{ Sample } & RFF & SA \\
\hline AG100 control & 0.5397 & 0.000 \\
\hline + TZ positive control. 30 mg/l & 11.8703 & 0.6998 \\
\hline + TF-1 $7.5 \mathrm{mg} / \mathrm{l}$ & 5.0638 & $\mathbf{1 . 1 1 7 6}$ \\
\hline + TF-2 $3.75 \mathrm{mg} / \mathrm{l}$ & 12.9179 & $\mathbf{6 . 1 1 6 0}$ \\
\hline + TF-3 $3.75 \mathrm{mg} / \mathrm{l}$ & 10.4916 & $\mathbf{4 . 9 1 7 2}$ \\
\hline + TF-4 30 mg/l & 31.1324 & $\mathbf{1 . 8 8 9 4}$ \\
\hline + TF-5 $7.5 \mathrm{mg} / \mathrm{l}$ & 7.8839 & $\mathbf{1 . 8 1 4 3}$ \\
\hline + TF-6 $30 \mathrm{mg} / \mathrm{l}$ & 5.1950 & 0.2875 \\
\hline + TF-7 $240 \mathrm{mg} / \mathrm{l}$ & 7.2390 & 0.0517 \\
\hline + TF-8 $60 \mathrm{mg} / \mathrm{l}$ & 6.9595 & 0.1982 \\
\hline + TF-9 $7.5 \mathrm{mg} / \mathrm{l}$ & 6.4451 & $\mathbf{1 . 4 5 8 9}$ \\
\hline + TF-10 $240 \mathrm{mg} / \mathrm{l}$ & 19.3553 & 0.1452 \\
\hline + TF-11 $120 \mathrm{mg} / \mathrm{l}$ & 6.6206 & 0.0938 \\
\hline + TF-12 $60 \mathrm{mg} / \mathrm{l}$ & 7.0865 & 0.2021 \\
\hline
\end{tabular}

RFF: relative final fluorescence; SA: specific activity $=\mathrm{RFF} /(0.5 \mathrm{MIC})$.

Samples consisted of saline plus $1 \mathrm{mg} / \mathrm{l}$ of EB, $0.4 \%$ glucose, without or with half the MIC of the positive control and TFs. Fluorescence was assassed at $37^{\circ} \mathrm{C}$ for $30 \mathrm{~min}$. Data in bold idicate TFs that expressed very high inhibitory activities against the efflux pump system of $E$. coli.

\subsection{Bacterial-bacterial interactions in QQ}

Our results reflect ex vivo interactions, and exemplify various bacterial interactions on QS. We investigated 31 bacteria and 3 yeast strains for their ability to inhibit or modify QS (Tables 10 and 11), of which 2 bacterial genera, Escherichia and Bacillus, proved to be effective inhibitors. Of the 6 investigated bacillus strains, B. cereus was the best inhibitor, with a clear QS inhibitory effect (Fig. 20), while B. subtilis and B. clausii inhibited QS moderately, and the 3 B. megaterium strains (PV361, MS941 and 216) did not exhibit any QS inhibitory activity (Table 10). Surprisingly, 14 of the 15 investigated Escherichia clinical isolates were effective inhibitors, and only 1 had no inhibitory effect. We investigated the QS inhibitory activity between E. cloaceae 31298 and CV026 and also that between EZF 10-17 and CV026: 10 strains exerted an antibacterial effect on E. cloaceae, and 4 of them inhibited the growth of CV026 too (Table 11). The antibacterial effects of the E. coli isolates on $E$. cloaceae were more pronounced than those on EZF 10-17. This probably originated from the long co-evolution in the same niche. The 2 strains with antibacterial activity on EZF 10-17 also had antibacterial effects on E. cloaceae 31298 and CV026. There were 5 strains which had no growth inhibitor activity against either the sensor or the producer strains. 


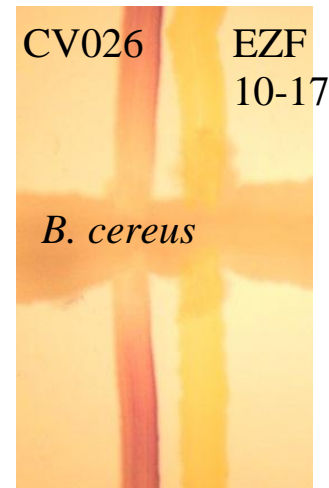

Figure 20.

QS inhibitory activity of $B$. cereus in the system containing the CV026 sensor and the EZF 10-17 producer strain. The inhibition of QS is revealed in the decreased level of violacein production.

Table 10.

Effects of various bacterial and Candida species on QS signal transmission.

\begin{tabular}{|c|c|c|}
\hline Strain & Medium & QS inhibition \\
\hline Candida albicans 40502 & LB* & - \\
\hline Candida tropicalis 47402 & $\mathrm{LB}^{*}$ & - \\
\hline Candida krusei 47813 & $\mathrm{LB}^{*}$ & - \\
\hline $\begin{array}{l}\text { Acinetobacter baumannii } \\
32703\end{array}$ & $\mathrm{LB}^{*}$ & - \\
\hline $\begin{array}{l}\text { Acinetobacter baumannii } \\
32905\end{array}$ & $\mathrm{LB}^{*}$ & - \\
\hline $\begin{array}{l}\text { Acinetobacter baumannii } \\
42701\end{array}$ & $\mathrm{LB}^{*}$ & - \\
\hline $\begin{array}{l}\text { Achromobacter xylosoxidans } \\
40502\end{array}$ & $\mathrm{LB}^{*}$ & - \\
\hline Staphylococcus aureus & $\mathrm{LB}^{*}$ & - \\
\hline Staphylococcus epidermidis & $\mathrm{LB}^{*}$ & - \\
\hline Bacillus subtilis & $\mathrm{LB}^{*}$ & Moderate \\
\hline Bacillus cereus & LB* & + \\
\hline Bacillus clausii & $\mathrm{LB}^{*}$ & Moderate \\
\hline Bacillus megaterium PV 361 & $\mathrm{LB}^{*}$ & - \\
\hline Bacillus megaterium MS 941 & $\mathrm{LB}^{*}$ & - \\
\hline Bacillus megaterium 216 & LB* & - \\
\hline Streptococcus pneumoniae & blood agar & - \\
\hline Streptococcus salivarius & blood agar & - \\
\hline Streptococcus agalactiae & blood agar & - \\
\hline Streptococcus pyogenes & blood agar & - \\
\hline
\end{tabular}

All of the 15 tested E. coli isolates except strain 19579 modified the QS (Table 11). The most exciting strains were 5539, 24310, 33444 and 40312, which strongly inhibited the established 
QS system, but the tested isolates did not affect the growth of the indicator and 2 producer strains (Fig. 21).

Interestingly, phenothiazines enhanced the QS-inhibitory effect of the ineffective $E$. coli 19579 and the 2 Bacillus strains, which displayed moderate QS-inhibitory effects without phenothiazines.

Table 11.

Effects of various E. coli strains on the QS signal transmission between CV026 sensor and

E. coli
strain

wth inhibition of

number CV026

5536 -

$10902+$

$10904+$

11925 -

$14525-$

14584 + low

$18596+$ low

19579 -

$19672+$

24310

24409

24442

33444

36446 -

40312
EZF 10-17 and E. cloaceae 31298 AHL producer strains.

\section{Growth}

inhibition of EZF Growth inhibition of

10-17 E. cloaceae 31298

QS inhibition

\section{$+$}

$+$

+ (very low)

$+$

$+$

$+$

-

$+$

$+$

$+$

$+$

+ (very low)

$+$

$+$

$+$
Origin of isolate (specimen)

Abscess

blood culture blood culture

blood culture

abdominal wound

Conjunctiva

Wound

Urine

Urine

blood culture

blood culture

blood culture

blood culture

blood culture

blood culture 


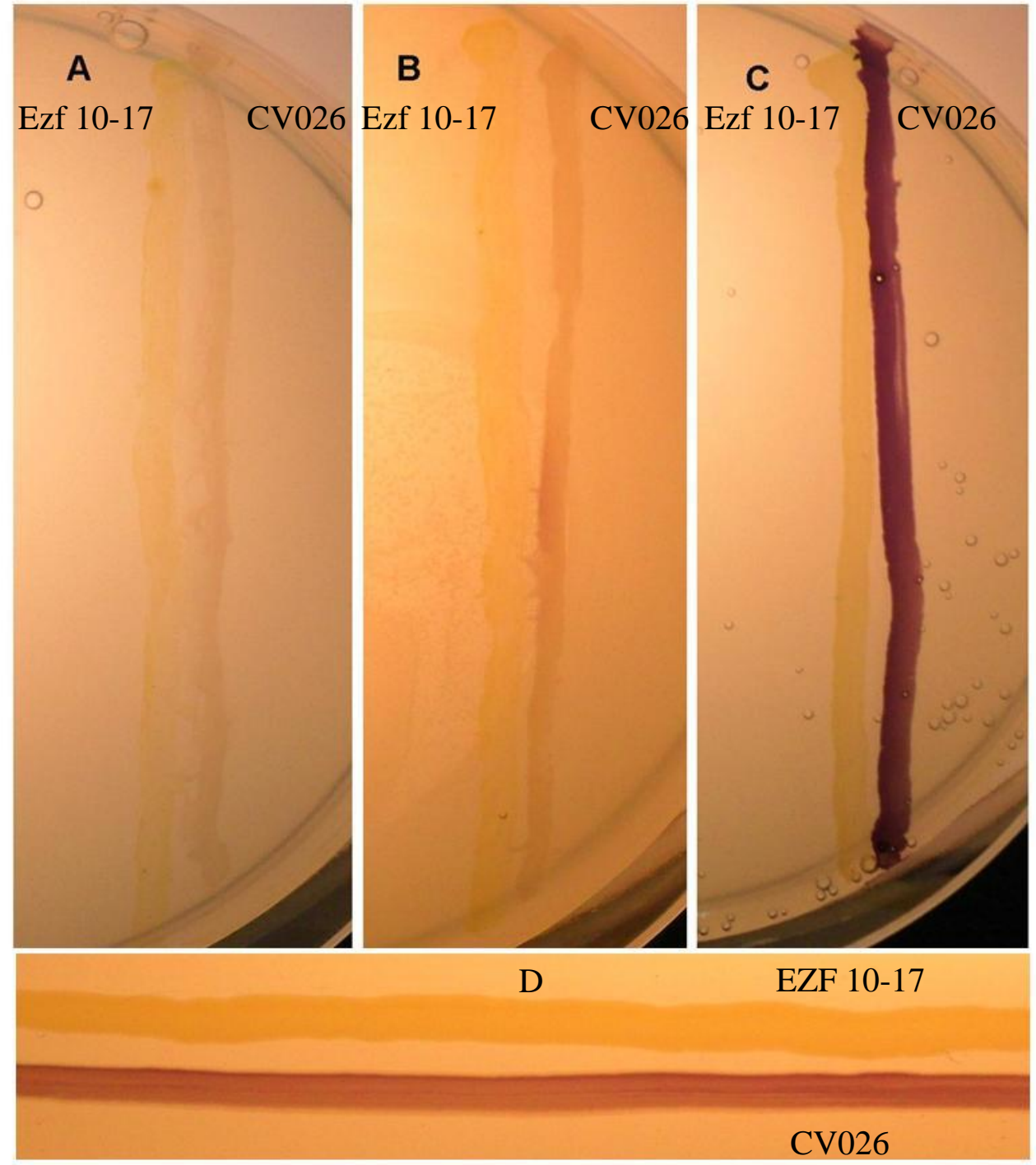

Figure 21.

The interference of different $E$. coli strains with the QS signal between the CV026 sensor and the EZF 10-17 producer strain.

The sensor and producer strains are situated on the top of the medium containing different $E$. coli strains.

A: Strain 5536 lacks QS between the sensor CV026 and producer EZF 10-17 strains.

B: Strain 11925 has high QS-inhibitory activity.

C: Strain 19579 has no QS-inhibitory activity.

D: Control. 


\section{Discussion}

The discovery of QS has opened up new perspectives in modern microbiology. QS is necessary in many crucial bacterial features e.g. biofilm formation (127), virulence factor production (128), competence (1), sporulation (129), antibiotic production (130) and resistance (131). Without communication, the microbes are lose the ability to fight as a unit against the immune system, produce virulence factors or organize biofilms. On the whole, it is impossible for most the bacteria to cause infections without QS. On the other hand, the increasing level of antibiotic resistance is currenly the greatest problem in microbiology. Most bacteria tolerate at least a few antibiotics, and, unfortunately, numerous multiresistant strains have appeared, which have also adapted to the latest antibiotics. The investigation of QS is therefore of increasing significance. In the future, QS inhibitors may offer a new perspective in the fight against multiresistant infections and take over the function of decaying antibiotics. Numerous compounds have been investigated in this search of QS inhibitors. Three main categories, essential oils, tricyclic compounds, and TFs proved to be the best inhibitors. These compounds and bacterial-bacterial co-existence are discussed below.

Essential oils: Land plants have co-evolved with microorganisms during 700 million years ago (132). Plants therefore produce various molecules which have effects on bacteria. Some attract microbes with beneficial effects, some are antibacterials, and some influence the bacterial QS (133). Because of the long co-evolution, probably the best source of different QSI compounds is to be found in plants. We investigated numerous essential oils and pure compounds for their QS inhibition. Many of them exert a QSI effect and it was found that most ethnomedical plants used against bacterial infections, also have a QSI ability. Purified plant QSI compounds, e.g. ajoene from garlic or thymol from thyme, in combination with antibiotics, will probably prove a good alternative to fight against complex bacterial infections.

Tricyclic compounds: The effects of tricyclic compounds on various Gram-positive and Gram-negative bacteria and R-plasmid elimination were examined earlier $(124,134)$, and the inhibition of horizontal plasmid transfer due to the blocked conjugation (135), antibacterial and plasmid curing in co-existing bacterial populations is known. The importance of tricyclic compounds as a class of "non-antibiotics" which may provide alternatives to the ineffective therapy of serious bacterial infections has already been reviewed (136). Despite this considerable body of evidence, the effects of tricyclic compounds on QS have not been 
studied before. Obviously, if the specific QS system is blocked during the bacterial infectious process, the therapy of serious infections may be improved. In view of the demonstration that certain tricyclic compounds can block the QS signal response of diverse bacterial species, it is conceivable that in the future these compounds may be used to modify biological signal transmission at a population level, e.g. by the modification of antibiotic resistance in biofilms, the production of virulence factors and the antibiotic production of some microbes in combination with conventional therapy to reduce the virulence of certain types of bacterial infections.

TFs: The results presented in this study show that some TFs have inhibitory activities against the response of CV026 to a QS signal such as AHL and the efflux pump systems of the CV026 and E. coli strains. Comparison of the efflux pump inhibitory activities of the TFs towards both strains suggests that the inhibition is practically identical in each case. This suggests that the TFs are of clinical value. Comparison of the individual inhibition induced by each TF on the QS response by CV026 to AHLs indicates that it is TF-3 that exerts the greatest inhibition on the QS response. From comparisons of the MIC of each effective TF, it is clear that the most effective inhibitors of the efflux pump system of E. coli also have the most potent antibacterial activities. TFs such as TF-7, 10 and 11 are devoid of any significant antibacterial activity (the MIC for TF-7 and 10 is $480 \mathrm{mg} / 1$, and for TF- 11 , it is $240 \mathrm{mg} / \mathrm{l}$ ) and have little activity against the efflux pump of $E$. coli. The demonstration of a QS response by the method used in this study requires the growth of the responding organism. If an agent inhibits growth, it pre-empts any response since there are no bacteria present to respond. The application of $20 \mu \mathrm{g}$ of each TF to discs promoted strong antibacterial effects by TFs with very low MICs. Applying amounts of a TF that has significant antibacterial properties to a disc below the inhibitory concentration exceeds the sensitivity of the system, since the distance between evident growth and the absence of a response (no colour) is masked by the deep purple colour associated with the growing population that is less than a millimetre from the disc. This is why TFs with very high MICs were able to produce evidence of an inhibition of the QS response by CV026, whereas for TFs with low MICs, with the exception of TF-3 (MIC $7.5 \mathrm{mg} / \mathrm{l}$ ), the antibacterial effect of the TF pre-empted growth. Our previous study demonstrated that phenothiazines were able to inhibit the QS system that involved EZF 10-17, the producer of the signal and CV026, the responder to the signal (125). The phenothiazine TZ, an inhibitor of efflux pumps of Gram-negative bacteria (119-122, 137), also inhibits the response of CV026 to pure AHL. Since phenothiazines and TFs that inhibit the efflux pumps of the CV026 and E. coli, as shown in the current study, also inhibit access to energy supplied 
by the proton motif force (PMF) $(138,139)$, we believe that the response to a QS signal depends upon a functional efflux pump system that deflects the noxious QS signal before it reaches its intended target. Moreover, as all the secretory activity of a bacterium, such as the secretion of a QS signal, is controlled (140-142), and the main efflux pump systems of Gramnegative bacteria are the secretory paths of internally produced noxious agents (143-146), inhibition of the efflux pump system of a QS signal producer will result in obviating the secretion of the QS signal. Therefore, it is our contention that inhibitors of an efflux pump, such as phenothiazines and now also TFs, will inhibit the QS. The results of the current study clearly show that various TFs have the ability to inhibit the response of $C$. violaceum 026 to the QS signal AHL and to inhibit the efflux pump of the QS-responding CV026 and that of $E$. coli. This ability is a direct one since none of the TFs formed a complex with AHL. In view of the fact that some TFs inhibit the QS response, inhibit an efflux pump system and also have significant antibacterial activity, TFs have a promising future for the therapy of problematic infections that rely on an efflux-mediated multidrug-resistant phenotype and which, due to QS, make their therapy problematic.

Bacterial interactions: In nature, bacteria live in a complex environment, in which they share their niche with a number of other bacterial and eukaryotic cells. Bacterial cells must select among numerous alternatives to find the most advantageous way to co-exist with their neighbours and to maintain their own optimum population level. They may gain benefit from the QQ of other species. The microbial world is very complex, with an abundance of social interactions, and bacteria with QS systems can acquire many benefits. Mixed bacterial infections are common in oropharyngeal, gastrointestinal and urinary tract infections. The presence of different bacterial species can result in difficulties in chemotherapy because the co-existing bacterial population can modify the interspecies communications and horizontal gene transfer (139 Molnár). Nature provides numerous examples of bacterial-bacterial and eukaryotic-bacterial interactions (63,64 148-153). As an example, a furanosyl borate diester, AI-2, a universal signal molecule that is characteristic in both Gram-negative and Grampositive bacteria, plays a very important role in bacterial-bacterial interspecies communication. Bacteria also synthesize molecules with special effects on eukaryotic cells. For instance, $P$. aeruginosa operates with a signal molecule, N-3-O-dodecanoyl homoserine lactone, which exerts various effects on mammalian cells, induces apoptosis and modulates the expression of immune mediators in murine fibroblast and human vascular epithelial cells (149). Among the many alternatives available to silence the QS of competitive bacteria, probably the most common way is the production of lactonase, an enzyme which opens the 
lactone ring of AHLs, this being a characteristic feature of the majority of Bacillus species (147). Another widely used alternative for inactivating AHLs is AHL-acylase production, which can occur in both Gram-positive and Gram-negative bacteria. These enzymes are more specific than lactonases. The AHL-acylase of Ralstonia eutropha is more effective on AHLs with a long acyl side-chain (150), whereas that of Streptomyces sp. strain M664 exerts a high AHL-degrading effect on AHLs with a short acyl side-chain (64). This is why a bacterium which communicates with short-chain AHLs can quench long acyl side-chain AHLs without affecting its own communication, and vice versa. Our results have afforded some evidence of the complexity of bacterial-bacterial interactions. Of the tested isolates, E. coli strains proved to be the best inhibitors of the AHL-dependent QS, 14 of the 15 samples exhibiting an inhibitory effect. There are a number of possibilities to explain why $E$. coli strains are such good QS inhibitors in our system. They may produce molecules which compete with the AHL signals of CV026, or metabolize the signal molecules, or use systems such as the AI-2 importers. E. coli possesses a special strategy to compete with the AI-2 signals of other bacteria. E. coli strains have AI-2 specific importers, which are activated at a high level of the inducer molecules. The import of AI-2 eliminates these signals from the extracellular environment (148). These importers probably play a role in the AHL-dependent QS-inhibitory effects too in our system. Another, and perhaps the most likely way to reduce AHLs from the environment is the AHL sensing of E. coli. This bacterium cannot produce AHLs, but has special LuxR-solo receptors, SdiA, which allow it to detect foreign AHLs. This competitive binding probably reduces the number of signal molecules in the population below the threshold concentration $(154,155)$.

In spite of the fact that most QSI investigations, including my own studies, have been in vitro experiments, numerous in vivo studies underpin the effectiveness of anti-QS treatments. Two excellent examples are found in the serous pathogens: V. cholerae and S. aureus. The QS system of $V$. cholerae is really interesting. It promotes virulence factor production in low cell density, and switches to the dispersion state at high cell density. The application of externally added AIs can theoretically abolish cholera toxin production. Douan and March created an $E$. coli Nissle strain wich expresses the CAI-1 gene (156). This probiotic strain has proved very effective in in vivo mouse models. This experiment not only reveals a new treatment of cholera, but also highlights the potential power of probiotic bacteria to serve as AI vectors. Another example is found in $S$. aureus. These dangerous, highly antibiotic-resistant bacteria can be categorized in several groups as concerns their signal molecules. At least 4 types of $S$. aureus exist as concerns their AIPs. The AgrC receptor responds to its own AIP, but binds the 
signal molecules from the other groups without modifying the gene expression. This competitive binding ensures the seperiority of the first colonizing strain (89 Ji G 1997). The Lyons group synthetized an antagonist molecule traAIP-II, which inhibit the QS in all the 4 groups. It also inhibits the toxin production of the pathogen in mouse models (90 lyon 2000). To summarize, in the past nearly 40 years we have learned much about bacterial communication, but in my opinion what we see is nearly the tip of the iceberg. QS is still one of the most rapidly developing fields in microbiology. Many QS molecules, receptors or complete systems and QSI compounds are already known, but the great breakthrough is still to come. I fully expect that, in the near future, QSI based treatments against complicated bacterial infections will become available in human medicine.

\section{The following of our results are considered novel:}

The QSI activity of the investigated essential oils

The QSI activity of phenothiazines

The QSI activity of TFs, and the connection between efflux pump inhibitor activity and QSI activity of TFs

The AHL profile of and identification of EZF 10-17

The interaction of E. coli with AHL-based QS systems 


\section{Summary}

QS is population size-dependent gene regulation, mediated by small signal molecules called AIs. The natures of these molecules are very different, but most belong in 3 groups: AHLs are mainly used by Gram-negative bacteria, autoinducer II (AI-2) is used by both Gram-negatives and Gram-positives, and AIPs are used by Gram-positives. Some bacteria use AIs which do not fit these groups, e.g. the PQS, DSF or AI-3. QS is a widely prevalent feature of both Gram-negative and Gram-positive bacteria. There are many different types of QS systems, but each system relies on the same basics. Each bacterium synthesizes signal molecules in low amounts. When the population density is low, the number of signal molecules is also low, when the number of bacteria increases, the concentration of QS molecules increases. When the concentration of signal molecules exceeds a threshold concentration, a positive feedback starts, and the bacteria increase the production of signal molecules. At this very high concentration of QS molecules, they bind their receptors. The nature of the receptors can differ considerably in each case, but in the end of the process is the same: the initiation of target gene transcription. QS is necessary in many crucial bacterial features e.g. biofilm formation (127), virulence factor production (128), competence (1), sporulation (129), antibiotic production (130) and resistance (131). Without communication, the microbes are lose the ability to fight as a unit against the immune system, produce virulence factors or organize biofilms. In the present thesis, my attention focused on in vitro models of QS to investigate QSI alternatives. Numerous compounds have been investigated in this search of QS inhibitors. Three main categories, essential oils, tricyclic compounds, and triofluoroketone proton pump inhibitors (TFs) proved to be the best inhibitors. The bacterial-bacterial coexistence also investigated. Our results have afforded some evidence of the complexity of bacterial-bacterial interactions. Of the tested isolates, E. coli strains proved to be the best inhibitors of the AHL-dependent QS, 14 of the 15 samples exhibiting an inhibitory effect. Antibiotic resistance is the most important problem in modern microbiology. Bactericidal or bacteriostatic compounds exert strong selective pressure on microbes. Because of the irresponsible use of antibiotics, pathogenic bacteria nowadays often display resistance to at least a few medicines. The appearance of multidrug-resistant strains which tolerate the latest antibiotics too enhances this problem. There is an urgent need to discover new antimicrobial, antipathogenic and antivirulence drugs. QS inhibitors may be a good alternative to solve this situation. 


\section{6. Összefoglaló}

A „quorum” egy görög eredetű szó, igazán jó magyar megfelelője nincsen. Az ókori görög és római fórumokkal lehet összefüggésbe hozni. A döntéshozás ezen színterein, egy törvény elfogadásához vagy elvetéséhez létre kellett jönnie a quorumnak, azaz egy minimális többségnek ami a szavazás eredményességéhez szükséges. A quorum sensing, lényegében a mikrobák között sem zajlik másként, rengeteg olyan bakteriális gént ismerünk, amely csak bizonyos sejtkoncentráció felett aktiválódik. Számos különféle QS rendszert és jelmolekulát ismerünk, de a müködési elvük minden esetben azonos alapokon nyugszik. A baktériumok egy alap szinten mindig termelnek jelmolekulákat. Alacsony mikrobaszámnál a szignálmolekulák száma is alacsony marad, és nem indukálnak változást a génkifejeződésben. A baktériumszám növelésével a jelmolekulák száma is növekszik, amint elérik a küszöbkoncentrációt kötődnek a receptoraikhoz. A receptor típusok és szignál transzdukciós utak szintén nagyon változatosak, de végső soron minden esetben egyrészt a jelmolekulák termeléséért felelős gének, másrészt a struktúrgének transzkripcióját indukálják. A pozitív visszacsatolás hatására egyre több jelmolekula kerül a környezetbe, egyre több struktúrgén is íródik át, és bekövetkezik a baktériumpopuláció fenotipusbeli változása. Rendszerint a jelmolekulák szintézisének növelése együtt jár a receptorok szintézisének csökkenésével, így téve szabályozottá a reakciót. A szignál molekulák többsége 3 nagy csoportba sorolható: a Gram-pozitívokra jellemző autoinducer peptidekre, a Gram-negatívokra jellemző acyl homoszerin laktonokra és az interbakteriális kommukációban szerepet játszó autoinducer 2-re. Egyre több szignál molekulát ismerünk meg, amely nem sorolható be egyik csoportba sem, ilyenek például az AI-3, DSF, PQS és HHQ szignálok. Quorum sensing rendszerükkel az egysejtü élőlények is képesek bizonyos mértékben többsejtüként viselkedni. Az adott mikrobaközösségek egy egységként képesek organizálni biológiai folyamataikat. Napjaink egyik legnagyobb, minél sürgetőbb megoldást igénylő mikrobiológiai problémáját az egyre szélesebb körben terjedő antibiotikum rezisztencia jelenti. Ennek leküzdésére a különféle quorum sensing gátló szerek jelenthetnek alternatívát. A QS rendszerek a baktériumok legkülönfélébb tulajdonságait befolyásolják. Szerepük lehet az antibiotikum rezisztenciában, biofilm képződésben, a kompetencia kialakításában, virulencia faktorok termelésében, az antibiotikum termelésben, a biolumineszcenciában, a konjugációban, sporulációban, motilitásban és még számos egyéb tulajdonság kialakításában. Így egy hatásos QS blokkolóval meggátolhatjuk az antibiotikum rezisztencia terjedését, a biofilmek létrejöttét, vagy a virulencia faktorok termelését is. Ezáltal a kórokozók zöme elveszítené, vagy 
csökkentené az antibiotikum rezisztenciáját, virulenciáját és más QS mediált tulajdonságait. Munkám során célul tüztem ki, a quorum sensing gátlási lehetőségeinek vizsgálatát, különféle gátló anyagok keresését és tanulmányozását, a mikrobák egymás kommunikációs rendszereire való hatásának megfigyelését. Kísérleteim alapját a CV026 (Chromobacterium violaeum 026) szenzortörzs jelentette, mely rövid szénláncú AHL-ek jelenlétében lila pigmentet, violaceint termel. Segítségével több batériumtörzsnél is detektáltunk AHL termelést, melyek közül a P.aeriginosa 49010-et és az E. cloaceae 31298-at és az akkor még identifikálatlan EZF 1017-et használtuk a további munkákhoz. Kísérleteimben elsőként különféle illóolajok QS-re kifejtett hatását vizsgáltam. Az irodalmakban már említett (fokhagyma, kakukkfü) kivonatokon kívül is számos esetben mutattam ki QS gátlást, így például a rózsa, citrom, levendula, gólyaorr és rozmaringolaj esetében is. Két vegyületcsoport az ABC transzporter gátló háromgyürüs vegyületek és a proton pumpa gátló trifluorometil ketonok többsége esetében szintén erőteljes QS gátlás volt tapasztalható. A háromgyürüs vegyületek közül az amitriptilin fejtette ki a legerősebb hatást az AHL termelö törzsek segítségével végzett kísérletek esetében. A C6 HSL jelmolekula és a háromgyürüs vegyületek direkt interakcióján alapuló vizsgálatoknál pedig az imipramin gátolta legeredményesebben a QS-et. A vizsgált 12 protonpumpa gátló trifluorometil keton közül 6 bizonyult erős QS gátlónak. A trifluoro keton proton pumpa gátló TF vegyületek efflux pumpákra kifejtett hatását is vizsgáltuk. A legeredményesebb efflux pumpa gátlóknak ugyanazok a vegyületek bizonyultak, mint a legeredményesebb QS inhibitorok (TF-1, 2, 3, 4, 5, 9,). A különféle baktériumok egymás QS rendszereire való hatásának tanulmányozása során pedig a vizsgált 15 E. coli törzs közül 14 bizonyult hatásosnak. A jövőben a különféle QS gátló szerek óriási jelentőségre tehetnek szert a komplikált bakteriális fertőzések kezelésénél. 


\section{Acknowledgement}

I would like to express my greatest gratitude to my supervisor, Professor József Molnár for his skillful and understanding guidance and for the continuous support and encouragement throughout my studies.

I would like to thank for Professor Yvette Mándi, head of the Doctoral School of Interdisciplinary Medicine and former head of the Department of Medical Microbiology and Immunobiology for providing opportunity to work at the department. I also would like to thank for Dr Katalin Burián, the present head of the institute.

I owe thanks furthermore to Dr Ernő Szegedi for providing the CV026 strain and other bacteria, and always offer me up to date articles in the theme.

I would like to thank to Professor Noboru Motohashi and Professor Masami Kawase to provide me the TF compounds.

I wish to thank for Professor Leonard Amaral in the helping me with the Efflux pump experiments, Professor Michael A. Savka for the identification of EZF 10-17 and Dr Mónika Kerényi for providing me the $E$. coli strains.

I thank my present and former collegues: Dr. Zsuzsanna Schelz, Dr. Míra Ágnes Szabó, Dr. Gabriella Spengler, Dr. Ilona Mucsi, Dr. Julianna Serly, Vigyikánné Váradi Anikó, Ábrahám Marianna, Dr. Ana Martins, for their support in my work and for creating a pleasant a working environment.

Finally I wish to express my utmost gratitude for my family, my girlfriend and my friends for their support, love and patience trough all these years.

This thesis was supported financially by The Foundation for Cancer Research Szeged. 


\section{References}

1. Tomasz A. Control of the competent state in Pneumococcus by a hormone-like cell product: an example for a new type of regulatory mechanism in bacteria. Nature. 1965; 9;208(5006):155-9

2. Nealson KH, Platt T, Hastings JW. Cellular control of the synthesis and activity of the bacterial luminescent system. J Bacteriol. 1970; 104: 313-322.

3. Nealson KH and Hastings JW. Bacterial bioluminescence: its control and ecological significance. Microbiol Rev. 1979; 43(4): 496-518.

\section{4. http://upload.wikimedia.org/wikipedia/commons/c/cf/Quorum_sensing_diagram.png}

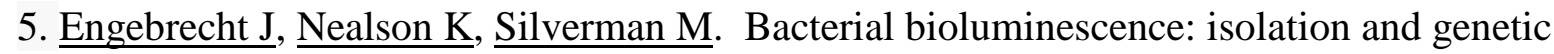
analysis of functions from Vibrio fischeri. Cell. 1983; 32(3):773-81.

6. Engebrecht J, Silverman M. Identification of genes and gene products necessary for bacterial bioluminescence Proc. Nati. Acad. Sci. 1984; 81:4154-4158.

7. Ochsner UA, Koch AK, Fiechter A, Reiser J. Isolation and characterization of a regulatorygene affecting rhamnolipid biosurfactant synthesis in Pseudomonas aeruginosa. J. Bacteriol. 1994; 176:2044-54.

8. Pearson JP, Gray KM, Passador L, Tucker KD, Eberhard A, et al. Structure of the autoinducer required for expression of Pseudomonas aeruginosa virulence genes. Proc. Natl. Acad. Sci. 1994; 91:197-201

9. Pearson JP, Passador L, Iglewski BH, Greenberg EP. A second N-acylhomoserine lactone signal produced by Pseudomonas aeruginosa. Proc. Natl. Acad. Sci. 1995; 92:1490-94

10. Wagner VE, Bushnell D, Passador L, Brooks AI, Iglewski BH. Microarray analysis of Pseudomonas aeruginosa quorum-sensing regulons: effects of growth phase and environment. J. Bacteriol. 2003; 185:2080-95 
11. Wagner VE, Gillis RJ, Iglewski BH. Transcriptome analysis of quorum-sensing regulation and virulence factor expression in Pseudomonas aeruginosa.Vaccine 2004; 22(Suppl. 1):S1520

12. Subramoni S, Venturi V. LuxR-family 'solos': bachelor sensors/ regulators of signalling molecules. Microbiology. 2009; 155:1377-1385.

13. Jimenez PN, Koch G, Thompson JA, Xavier KB, Cool RH, Quax WJ. The multiple signaling systems regulating virulence in Pseudomonas aeruginosa. Microbiol. Mol. Biol. Rev. 2012; 76:46-65

14. La sarre B, Federle JM. Exploiting quorum sensing to confuse bacterial pathogens. Microbiol. Mol. Biol. Rev. 2013; 77:73-111

15. Fuqua WC, Winans SC. A LuxR-LuxI type regulatory system activates Agrobacterium Ti plasmid conjugal transfer in the presence of a plant tumor metabolite. J. Bacteriol. 1994; 176:2796-806

16. Szegedi E, Otten L. Incompatibility properties of tartrate utilization plasmids derived from Agrobacterium vitis strains. Plasmid. 1998; 39(1):35-40.

17. Waters CM, Bassler BL. Quorum sensing: cell-to-cell communication in bacteria. Annu Rev Cell Dev Biol. 2005; 21:319-46.

18. Miller MB, Bassler BL. Quorum sensing in bacteria. Annu. Rev. Microbiol. 2001; 55:165199

19. Novick RP, Proyan SJ, Kornblum J, Ross HF, Ji G, et al. The agr P2 operon: an autocatalytic sensory transduction system in Staphyllococcus aureus. Mol. Gen. Genet. 1995; 248:446-58

20. Novick RP. Autoinduction and sygnal transduction in the regulation of staphylococcal virulence. Mol. Microbiol. 2003; 48:1429-49 
21. Harvastein LS, Coomaraswamy G, Morrison DA. An unmodified heptadecapeptide pheromone induces competence for genetic transformation in Sterptococcus pneumoniae. Proc. Natl. Acad. Sci. 1995; 92:11140-44

22. Pestova EV, Havarstein LS, Morrison DA. Regulation of competence for genetic transformation in Streptococcus pneumoniae by an auto-induced peptide pheromone and a two-component regulatory system. Mol. Microbiol. 1996; 21:853-62

23. Parsek MR, Val DL, Hanzelka BL, Cronan JE, Jr, Greenberg EP. Acyl homoserinelactone quorum-sensing signal generation. Proc. Natl. Acad. Sci. 1999; 96:4360-4365.

24. Ansaldi M, Marolt D, Stebe T, Mandic-Mulec I, Dubnau D. Specific activation of the Bacillus quorum-sensing systems by isoprenylated pheromone variants. Mol. Microbiol. 2002; 44:1561-73

25. Mayville P, Ji G, Beavis R, Yang H, Goger M, et al. Structure activity analysis of synthetic autoinducing thiolactone peptides from Staphyllococcus aureus responsible for virulance. Proc. Natl. Acad. Sci. 1999; 96:1218-23

26. Nakayama J, Cao Y, Horii T, Sakuda S, Akkermans AD, et al. Gelatinase biosynthesisactivating pheromone: a peptide lactone that mediates a quorum sensing in Enterococcus faecalis. Mol. Microbiol. 2001; 41:145-54

27. Rocha-Estrada J, Aceves-Diez AE, Guarneros G, de la Torre M. The RNPP family of quorum-sensing proteins in Gram-positive bacteria. Appl. Microbiol. Biotechnol. 2010; 87:913-923.

28. Dubois T, Faegri K, Perchat S, Lemy C, Buisson C, Nielsen-LeRoux C, Gohar M, Jacques P, Ramarao N, Kolsto AB, Lereclus D. Necrotrophism is a quorum-sensing-regulated lifestyle in Bacillus thuringiensis. PLoS Pathog. 2012; 8:e1002629. doi:10.1371/journal.ppat.1002629.

29. Rocha J, Flores V, Cabrera R, Soto-Guzman A, Granados G, Juaristi E, Guarneros G, de la Torre M. Evolution and some functions of the NprR-NprRB quorum-sensing system in the Bacillus cereus group. Appl. Microbiol. Biotechnol. 2012; 94:1069 -1078. 
30. Schauder S, Shokat K, Surette MG \& Bassler BL The LuxS family of bacterial autoinducers: biosynthesis of a novel quorum-sensing signal molecule. Mol Microbiol 2001; $41: 463-476$.

31. Winzer K, Hardie KR, Burgess $\mathrm{N}$ et al. LuxS: its role in central metabolism and the in vitro synthesis of 4-hydroxy-5-methyl-3(2H)-furanone. Microbiology 2002; 148:909-922.

32. Chen X, Schauder S, Potier N, Van Dorsselaer A, Pelczer I, Bassler BL \& Hughson FM Structural identification of a bacterial quorum-sensing signal containing boron. Nature 2002; 415: 545-549.

33. Tavender TJ, Halliday NM, Hardie KR \& Winzer K. LuxS-independent formation of AI2 from ribulose-5-phosphate. BMC Microbiol 2008; 8:98.

34. Bordignon E, Grote M \& Schneider E. The maltose ATP-binding cassette transporter in the 21 st century - towards a structural dynamic perspective on its mode of action. Mol Microbiol 2010; 77: 1354-1366.

35. Miller ST, Xavier KB, Campagna SR, Taga ME, Semmelhack MF, Bassler BL \& Hughson FM. Salmonella typhimurium recognizes a chemically distinct form of the bacterial quorum-sensing signal AI-2. Mol Cell 2004; 15: 677-687.

36. Pereira CS, de Regt AK, Brito PH, Miller ST \& Xavier KB. Identification of functional LsrB-like autoinducer-2 receptors. J Bacteriol 2009; 191: 6975-6987.

37. Kavanaugh JS, Gakhar L \& Horswill AR. The structure of LsrB from Yersinia pestis complexed with autoinducer-2. Acta Crystallogr Sect F Struct Biol Cryst Commun 2011; 67:1501-1505.

38. Shao H, James D, Lamont RJ \& Demuth DR. Differential interaction of Aggregatibacter (Actinobacillus) actinomycetemcomitans LsrB and RbsB proteins with autoinducer 2. J Bacteriol 2007; 189: 5559-5565. 
39. James D, Shao H, Lamont RJ \& Demuth DR. The Actinobacillus

actinomycetemcomitans ribose binding protein $\mathrm{RbsB}$ interacts with cognate and heterologous autoinducer 2 signals. Infect Immun 2006; 74: 4021-4029.

40. Dubern JF, Diggle SP. Quorum sensing by 2-alkyl-4-quinolones in Pseudomonas aeruginosa and other bacterial species. Mol. Biosyst. 2008 4:882- 888.

41. Deng Y, Wu J, Tao F, Zhang LH. Listening to a new language: DSF-based quorum sensing in Gram-negative bacteria. Chem. Rev. 2011; 111:160-173.

42. Deng Y, Schmid N, Wang C, Wang J, Pessi G, Wu D, Lee J, Aguilar C, Ahrens CH, Chang C, Song H, Eberl L, Zhang LH. Cis-2-dodecenoic acid receptor RpfR links quorumsensing signal perception with regulation of virulence through cyclic dimeric guanosine monophosphate turnover. Proc. Natl. Acad. Sci. 2012; 109:15479 -15484.

43. Kendall MM, Sperandio V. Quorum sensing by enteric pathogens. Curr. Opin. Gastroenterol. 2007; 23:10-15.

44. Moreira CG, Weinshenker D, Sperandio V. QseC mediates Salmonella enterica serovar typhimurium virulence in vitro and in vivo. Infect. Immun. 2010; 78:914 -926.

45. Tiaden A, Spirig T, Hilbi H. Bacterial gene regulation by alphahydroxyketone signaling. Trends Microbiol. 2010; 18:288-297.

46. Pereira CS, Jessica AT and Xavier Periera KB: AI-2 mediated signaling in bacteria. FEMS Microbiology Reviews 2013; 37(2):156-181.

47. Hoang TT, Schweizer HP. Characterization of Pseudomonas aeruginosa enoyl-acyl carrier protein reductase $(\mathrm{FabI})$ : a target for the antimicrobial triclosan and its role in acylated homoserine lactone synthesis. J. Bacteriol. 1999; 181:5489-5497.

48. Chung J, Goo E, Yu S, Choi O, Lee J, Kim J, Kim H, Igarashi J, Suga H, Moon JS, Hwang I, Rhee S. Small-molecule inhibitor binding to an N-acyl-homoserine lactone synthase. Proc. Natl. Acad. Sci. 2011; 108:12089-12094. 
49. Singh V, Evans GB, Lenz DH, Mason JM, Clinch K, Mee S, Painter GF,Tyler PC, Furneaux RH, Lee JE, Howell PL, Schramm VL. Femtomolar transition state analogue inhibitors of 5=-methylthioadenosine/S-adenosylhomocysteine nucleosidase from Escherichia coli. J. Biol. Chem. 2005; 280:18265-18273.

50. Lee JE, Singh V, Evans GB, Tyler PC, Furneaux RH, Cornell KA, Riscoe MK, Schramm VL, Howell PL. Structural rationale for the affinity of pico- and femtomolar transition state analogues of Escherichia coli 5=-methylthioadenosine/S-adenosylhomocysteine nucleosidase. J. Biol. Chem. 2005; 280:18274-18282.

51. Alfaro JF, Zhang T, Wynn DP, Karschner EL, Zhou ZS. Synthesis of LuxS inhibitors targeting bacterial cell-cell communication. Org. Lett. 2004; 6:3043-3046.

52. Shen G, Rajan R, Zhu JG, Bell CE, Pei DH. Design and synthesis of substrate and intermediate analogue inhibitors of S-ribosylhomocysteinase. J. Med. Chem. 2006; 49:30033011.

53. Zang T, Lee BW, Cannon LM, Ritter KA, Dai S, Ren D, Wood TK, Zhou ZS. A naturally occurring brominated furanone covalently modifies and inactivates LuxS. Bioorg. Med. Chem. Lett. 2009; 19:6200-6204.

54. Calfee MW, Coleman JP, Pesci EC. Interference with Pseudomonas quinolone signal synthesis inhibits virulence factor expression by Pseudomonas aeruginosa. Proc. Natl. Acad. Sci. 2001; 98(20):11633-7

55. Cugini C, Calfee MW, Farrow JM, III, Morales DK, Pesci EC, Hogan DA. Farnesol, a common sesquiterpene, inhibits PQS production in Pseudomonas aeruginosa. Mol. Microbiol. 2007; 65:896-906.

56. Nakayama J, Uemura Y, Nishiguchi K, Yoshimura N, Igarashi Y, Sonomoto K. Ambuic acid inhibits the biosynthesis of cyclic peptide quormones in gram-positive bacteria. Antimicrob. Agents Chemother. 2009; 53:580-586. 
57. Dong YH, Xu JL, Li XZ, Zhang LH. AiiA, an enzyme that inactivates the acylhomoserine lactone quorum-sensing signal and attenuates the virulence of Erwinia carotovora. Proc. Natl. Acad. Sci. 2000; 97:3526-3531.

58. Chun CK, Ozer EA, Welsh MJ, Zabner J, Greenberg EP. Inactivation of a Pseudomonas aeruginosa quorum-sensing signal by human airway epithelia. Proc. Natl. Acad. Sci. 2004; 101:3587-3590.

59. Yang F, Wang LH, Wang J, Dong YH, Hu JY, Zhang LH. Quorum quenching enzyme activity is widely conserved in the sera of mammalian species. FEBS Lett. 2005; 579:37133717 .

60. Ozer EA, Pezzulo A, Shih DM, Chun C, Furlong C, Lusis AJ, Greenberg EP, Zabner J. Human and murine paraoxonase 1 are host modulators of Pseudomonas aeruginosa quorumsensing. FEMS Microbiol. Lett. 2005; 253:29 -37.

61. Stoltz DA, Ozer EA, Ng CJ, Yu JM, Reddy ST, Lusis AJ, Bourquard N, Parsek MR, Zabner J, Shih DM. Paraoxonase-2 deficiency enhances Pseudomonas aeruginosa quorum sensing in murine tracheal epithelia. Am. J. Physiol. Lung Cell. Mol. Physiol. 2007; 292:L852- 860.

62. Teiber JF, Horke S, Haines DC, Chowdhary PK, Xiao J, Kramer GL, Haley RW, Draganov DI. Dominant role of paraoxonases in inactivation of the Pseudomonas aeruginosa quorum-sensing signal N-(3-oxododecanoyl)-L-homoserine lactone. Infect. Immun. 2008; 76:2512-2519.

63. Leadbetter JR, Greenberg EP. Metabolism of acyl-homoserine lactone quorum-sensing signals by Variovorax paradoxus. J. Bacteriol. 2000; 182:6921-6926.

64. Park SY, Kang HO, Jang HS, Lee JK, Koo BT, Yum DY. Identification of extracellular $\mathrm{N}$-acylhomoserine lactone acylase from a Streptomyces sp. and its application to quorum quenching. Appl. Environ. Microbiol. 2005; 71:2632-2641.

65. Shepherd RW, Lindow SE. Two dissimilar N-acyl-homoserine 
lactone acylases of Pseudomonas syringae influence colony and biofilm morphology. Appl. Environ. Microbiol. 2009; 75:45-53.

66. Sio CF, Otten LG, Cool RH, Diggle SP, Braun PG, Bos R, Daykin M, Camara M, Williams P, Quax WJ. Quorum quenching by an N-acyl-homoserine lactone acylase from Pseudomonas aeruginosa PAO1. Infect. Immun. 2006; 74:1673-1682.

67. Uroz S, Chhabra SR, Camara M, Williams P, Oger P, Dessaux Y. N-Acylhomoserine lactone quorum-sensing molecules are modified and degraded by Rhodococcus erythropolisW2by both amidolytic and novel oxidoreductase activities. Microbiology 2005; 151:3313-3322.

68. Chowdhary PK, Keshavan N, Nguyen HQ, Peterson JA, Gonzalez JE, Haines DC. Bacillus megaterium CYP102A1 oxidation of acyl homoserine lactones and acyl homoserines. Biochemistry 2007; 46:14429-14437.

69. Chowdhary PK, Stewart L, Lopez C, Haines DC. A single mutation in P450BM-3 enhances acyl homoserine lactone:acyl homoserine substrate binding selectivity nearly 250fold. J. Biotechnol. 2008; 135:374-376.

70. Kaufmann GF, Sartorio R, Lee SH, Mee JM, Altobell LJ, 3rd, Kujawa DP, Jeffries E, Clapham B, Meijler MM, Janda KD. Antibody interference with N-acyl homoserine lactonemediated bacterial quorum sensing. J. Am. Chem. Soc. 2006; 128:2802-2803.

71. Roy V, Fernandes R, Tsao CY \& Bentley WE. Cross species quorum quenching using a native AI-2 processing enzyme. ACS Chem. Biol. 2010; 5(2):223-232.

72. Newman KL, Chatterjee S, Ho KA, Lindow SE. Virulence of plant pathogenic bacteria attenuated by degradation of fatty acid cell-to-cell signaling factors. Mol. Plant Microbe Interact. $2008 ; 21: 326-334$.

73. Pustelny C, Albers A, Buldt-Karentzopoulos K, Parschat K, Chhabra SR, Camara M, Williams P, Fetzner S. 2009. Dioxygenase-mediated quenching of quinolone-dependent quorum sensing in Pseudomonas aeruginosa. Chem. Biol. 2009; 16:1259-1267. 
74. Park J, Jagasia R, Kaufmann GF, Mathison JC, Ruiz DI, Moss JA, Meijler MM, Ulevitch $\mathrm{RJ}$, Janda KD. Infection control by antibody disruption of bacterial quorum sensing signaling. Chem. Biol. 2007; 14: 1119-1127.

75. Eberhard A, Widrig CA, Mcbath P, Schineller JB. 1986. Analogs of the autoinducer of bioluminescence in Vibrio fischeri. Arch. Microbiol. 1986; 146:35-40.

76. Geske GD, O’Neill JC, Miller DM, Mattmann ME, Blackwell HE. Modulation of bacterial quorum sensing with synthetic ligands: systematic evaluation of $\mathrm{N}$-acylated homoserine lactones in multiple species and new insights into their mechanisms of action. J. Am. Chem. Soc. 2007; 129:13613-13625.

77. Olsen JA, Severinsen R, Rasmussen TB, Hentzer M, Givskov M, Nielsen J. Synthesis of new 3- and 4-substituted analogues of acyl homoserine lactone quorum sensing autoinducers. Bioorg. Med. Chem. Lett. 2002; 12:325-328.

78. McInnis CE, Blackwell HE. Thiolactone modulators of quorumsensing revealed through library design and screening. Bioorg. Med. Chem. 2011; 19:4820-4828.

79. Malladi VLA, Sobczak AJ, Maricic N, Murugapiran SK, Schneper L,Makemson J, Mathee K, Wnuk SF. Substituted lactam and cyclic azahemiacetals modulate Pseudomonas aeruginosa quorum sensing. Bioorgan. Med. Chem. 2011; 19:5500-5506.

80. Frezza M, Castang S, Estephane J, Soulere L, Deshayes C, Chantegrel B, Nasser W, Queneau Y, Reverchon S, Doutheau A. Synthesis and biological evaluation of homoserine lactone derived ureas as antagonists of bacterial quorum sensing. Bioorg. Med. Chem. 2006; $14: 4781-4791$.

81. Brackman G, Risseeuw M, Celen S, Cos P, Maes L, Nelis HJ, Van Calenbergh S, Coenye T. Synthesis and evaluation of the quorum sensing inhibitory effect of substituted triazolyldihydrofuranones. Bioorg. Med. Chem. 2012; 20:4737- 4743. 
82. Mattmann ME, Shipway PM, Heth NJ, Blackwell HE. Potent and selective synthetic modulators of a quorum sensing repressor in Pseudomonas aeruginosa identified from second-generation libraries of Nacylated L-homoserine lactones. Chembiochem 2011; 12:942-949.

83. Zhu P \& Li M. Recent progress on AI-2 bacterial quorum sensing inhibitors. Curr Med Chem 2012 19: 174186.

84. Defoirdt T, Miyamoto CM, Wood TK, Meighen EA, Sorgeloos P, Verstraete W, Bossier $\mathrm{P}$. The natural furanone (5Z)-4-bromo-5-(bromomethylene)-3-butyl-2(5H)-furanone disrupts quorum sensingregulated gene expression in Vibrio harveyi by decreasing the DNAbinding activity of the transcriptional regulator protein luxR. Environ. Microbiol. 2007; 9:2486-2495.

85. Manefield M, Welch M, Givskov M, Salmond GP, Kjelleberg S. Halogenated furanones from the red alga, Delisea pulchra, inhibit carbapenem antibiotic synthesis and exoenzyme virulence factor production in the phytopathogen Erwinia carotovora. FEMS Microbiol. Lett. $2001 ; 205: 131-138$.

86. Li MY, Ni NT, Chou HT, Lu CD, Tai PC, Wang BH. Structurebased discovery and experimental verification of novel Al-2 quorum sensing inhibitors against Vibrio harveyi. Chemmedchem 2008; 3:1242-1249.

87. Gamby S, Roy V, Guo M, Smith JA, Wang J, Stewart JE, Wang X, Bentley WE, Sintim HO. Altering the communication networks of multispecies microbial systems using a diverse toolbox of AI-2 analogues. ACS Chem. Biol. 2012; 7:1023-1030.

88. Lowery CA, Abe T, Park J, Eubanks LM, Sawada D, Kaufmann GF, Janda KD. Revisiting AI-2 quorum sensing inhibitors: direct comparison of alkyl-DPD analogues and a natural product fimbrolide. J. Am. Chem. Soc. 2009; 131:15584-15585.

89. Ji G, Beavis R, Novick RP. Bacterial interference caused by autoinducing peptide variants. Science 1997; 276:2027-2030. 
90. Lyon GJ, Mayville P, Muir TW, Novick RP. Rational design of a global inhibitor of the virulence response in Staphylococcus aureus, based in part on localization of the site of inhibition to the receptorhistidine kinase, AgrC. Proc. Natl. Acad. Sci. 2000; 97:13330 13335.

91. Zhu L, Lau GW. Inhibition of competence development, horizontal gene transfer and virulence in Streptococcus pneumoniae by a modified competence stimulating peptide. PLoS Pathog. 2011; 7:e1002241. doi:10.1371/journal.ppat.1002241.

92. Kostakioti M, Hadjifrangiskou M, Hultgren SJ. Bacterial biofilms: development, dispersal, and therapeutic strategies in the dawn of the postantibiotic era. Cold Spring Harb Perspect Med. 2013; 3(4):a010306. doi: 10.1101/cshperspect.a010306.

93. Venditti M, Biavasco F, Varaldo PE, Macchiarelli A, De Biase L, Marino B, Serra P. Catheter-related endocarditis due to glycopeptide-resistant Enterococcus faecalis in a transplanted heart. Clin Infect Dis. 1993; 17:524-525.

94. Ferrieres L, HancockV, Klemm P. Specific selection for virulent urinary tract infectious Escherichia coli strains during catheter-associated biofilm formation. FEMS Immunol Med Microbiol 2007; 51: 212-219.

95. Foxman B. The epidemiology of urinary tract infection. Nat Rev Urol 2010; 7: 653-660.

96. Kuramitsu HK,Wang BY. The whole is greater than the sum of its parts: Dental plaque bacterial interactions can affect the virulence properties of cariogenic Streptococcus mutans. Am J Dent. 2011; 24: 153-154.

97. Koch C, Hoiby N. Pathogenesis of cystic fibrosis. Lancet1993; 341:1065-1069.

98. Govan JR, Deretic V. Microbial pathogenesis in cystic fibrosis: Mucoid Pseudomonas aeruginosa and Burkholderia cepacia. Microbiol Rev 1996; 60:539-574.

99. Yarwood, J.M. et al. Quorum sensing in Staphylococcus aureus biofilms. J. Bacteriol. 2004; 186:1838-1850 
100. Cole, S.P. et al. Characterization of monospecies biofilm formation by Helicobacter pylori. J. Bacteriol. 2004; 186:3124-3132

101. Labbate, M. et al. Quorum sensing-controlled biofilm development in Serratia liquefaciens MG1. J. Bacteriol. 2004; 186:692-698

102. Huber, B. et al. The cep quorum-sensing system of Burkholderia cepacia H111 controls biofilm formation and swarming motility. Microbiology 2001; 147:2517-2528

103. Lynch, M.J. et al. The regulation of biofilm development by quorum sensing in Aeromonas hydrophila. Environ. Microbiol. 2002; 4:18-28

104. Merritt, J. et al. Mutation of luxS affects biofilm formation in Streptococcus mutans. Infect. Immun. 2003; 71:1972-1979

105. Dow, J.M. et al. Biofilmdispersal in Xanthomonas campestris is controlled by cell-cell signaling and is required for full virulence to plants. Proc. Natl. Acad. Sci. 2003; 100:1099511000

106. http://www.sigmaaldrich.com/content/dam/sigmaaldrich/structure4/157/mfcd01862908.eps/_jcr_content/renditions/medium.png

107. Kawase M, Teshima M, Saito S and Tani S: Trifluoroacetylation of methylpyridines and other methylazines: A convenient access to trifluoroacetonylazines. Heterocycles. 1998; 48:2103-2109,

108. Lipshutz BH, Hungate RW: Metalation studies of trisubstituted oxazoles. J Org Chem $1981 ; 46: 1410-1413$.

109. Babichev FS and Volovenko YM: Acylation of 2-methylbenzazoles by carboxylic acid esters. Ukrainskii Khimicheskii Zhurnal 1977; 43: 163-165. 
110. Ballantine, J. A., Beer, R. J. S., Crutchley, D. J., Dodd, G. M. \& Palmer, D. R. The synthesis os violacein and related compounds. Proc Chem Soc., 1958; 232-233

111. McClean KH, Winson MK, Fish L, Taylor A, Chhabra SR, Camara M, Daykin M, Lamb JH, Swift S, Bycroft BW, Stewart GSAB and Williams P. Quorum sensing and Chromobacterium violaceum: exploitation of violacein production and inhibition for the detection of $N$-acyl homoserine lactones. Microbiology, 1997; 143:3703-3711

112. Lithgow JK, Danino VE, Jones J and Downie JA. Analysis of $N$-acyl homoserine-lactone quorum-sensing molecules made by different strains and biovars of Rhizobium leguminosarum containing different symbiotic plasmids. Plant and Soil, 2001; 232:3-12 .

113. Molina L, Constantinescu F, Michel L, Reimman C, Duffy B and Défago G: Degradation of pathogen quorum-sensing molecules by soil bacteria: a preventive and curative biological control mechanism. FEMS Microbiology Ecology, 2003; 45:71-81

114. McClean RJC, Pierson LS and Fuqua C. A simple screening protocol for the identification of quorum signal antagonists. Journal of Microbiological Methods, 2004; 58:351-360.

115. Szabó MA, Varga GZ, Hohmann J, Schelz Z, Szegedi E, Amaral L, Molnár J. Inhibition of quorum-sensing signals by essential oils. Phytother. Res. 2010; 24(5):782-6.

116. Martins A, Iversen C, Rodrigues L, Spengler G, Ramos J, Kern WV, Couto I, Viveiros M, Fanning S, Pages JM and Amaral L: An AcrAB-mediated multidrug-resistant phenotype is maintained following restoration of wild-type activities by efflux pump genes and their regulators. Int J Antimicrob Agents 2009; 34:602-604.

117. Attila C, Ueda A, Wood TK. 5-Fluorouracil reduces biofilm formation in Escherichia coli K-12 through global regulator AriR as an antivirulence compound. Appl Microbiol Biotechnol . 2009; 82(3):525-33.

118. Clinical and Laboratory Standards Institute. Performance Standards for Antimicrobial Susceptibility Testing; Seventeenth Informational Supplement. CLSI document 2007; 27(1): M100-S17. 
119. Viveiros M, Martins M, Couto I, Rodrigues L, Spengler G, Martins A, Kristiansen JE, Molnar J and Amaral L: New Methods for the Identification of Efflux-mediated MDR Bacteria; Genetic Assessment of Regulators and Efflux Pump Constituents, Characterization of Efflux Systems and Screening for Inhibitors of Efflux Pumps: Current Drug Targets 2008; 9:760-778.

120. Viveiros M, Rodrigues L, Martins M, Couto I, Spengler G, Martins A and Amaral L: Evaluation of efflux activity of bacteria by a semi-automated fluorometric system. Methods Mol Biol 2010; 642:159-172.

121. Takacs D, Cerca P, Martins A, Riedl Zs, Hajos Gy, Molnar J, Viveiros M, Couto I and Amaral L: Evaluation of forty new phenothiazine derivatives for activity against intrinsic efflux pump systems of reference Escherichia coli, Salmonella Enteritidis, Enterococcus faecalis and Staphylococcus aureus strains. In Vivo 2011; 25: 719-724.

122. Amaral L, Cerca P, Spengler G, Machado L, Martins A, Couto I, Viveiros M, Fanning S and Pages JM: Ethidium bromide efflux by Salmonella: modulation by metabolic energy, $\mathrm{pH}$, ions and phenothiazines. Int J Antimicrob Agents 2011; 38: 140-145.

123. Schelz Zs, Molnar J., Hohhmann J. Antimicrobial and antiplasmid activity of essential oils. Fitoterapia 2006; 77:279-285.

124. Molnár J., Király J, Mándi Y.: The antibacterial action of R-factor inhibiting activity by chlorpromazine. Experientia, 1975; 31:444-445

125. Varga GZ, Szabo MA, Schelz Zs, Szegedi E, Amaral L, Molnár J. Quorum Sensing Inhibition by Phenothiazines and Related Compounds. Lett Drug Design Discovery 2011; 8: 133-137.

126. Wolfart $K$, Spengler G, Kawase M, Motohashi $N$, Molnár J, Viveiros M, Amaral L. Synergistic interaction between proton pump inhibitors and resistance modifiers: promoting effects of antibiotics and plasmid curing. In vivo 2006; 20(3):367-72. 
127. Waters CM, Lu W, Rabinowitz JD, Bassler BL: Quorum sensing controls biofilm formation in Vibrio cholerae through modification of cyclic di-GMP levels and repression of vpsT. J Bacteriol. 2008; 190(7):2527-36

128. Koch G, Nadal-Jimenez P, Reis CR, Muntendam R, Bokhove M, Melillo E, Dijkstra BW, Cool RH, Quax WJ. Reducing virulence of the human pathogen Burkholderia by altering the substrate specificity of thequorum-quenching acylase PvdQ. Proc Natl Acad Sci 2014; 28:111(4):1568-73.

129. Steiner E, Scott J, Minton NP, Winzer K. An agr quorum sensing system that regulates granulose formation and sporulation in Clostridium acetobutylicum. Appl Environ Microbiol. 2012; 78(4):1113-22.

130. Yang YH, Song E, Kim EJ, Lee K, Kim WS. NdgR, an IclR-like regulator involved in amino-acid-dependent growth, quorum sensing, and antibiotic production in Streptomyces coelicolor. Appl. Microbiol. Biotechnol. 2009; 82(3):501-511.

131. Yang YX, Xu ZH, Zhang YQ, Tian J, Weng LX, Wang LH. A new quorumsensing inhibitor attenuates virulence and decreases antibiotic resistance in Pseudomonas aeruginosa. J Microbiol. 2012; 50(6):987-93.

132. Heckman DS, Geiser DM, Eidell BR, Stauffer RL, Kardos NL, Hedges SB. Molecular evidence for the early colonization of land by fungi and plants. Science 2001; 293:1129-33

133. Venturi V and Fuqua C. Chemical Signalling Between Plants and Plant-Pathogenic Bacteria. Annu. Rev. Phytopathol 2013; 51:17-37

134. Mándi Y, Molnár J, Holland IB, and Béládi I. Efficient curing of an Escherichia coli Fprime plasmid by phenothiazines. Genet. Res. 1976; 26:109-111.

135. Mándi Y, Molnár J. Effect of chlorpromazine on conjugal plasmid transfer and sex pili. Acta microbiol. Acad. Sci. Hung. 1981; 28:205-210. 
136. Spengler G, Miczák A, Hajdú E, Kawase M, Amaral L \& Molnár J. Enhancement of plasmid curing by 9-aminoacridine and two phenothiazines in the presence of proton pump inhibitor 1-(2-benzoxazolyl)-3,3,3-trifluoro-2-propanone. Int J Antimicrob Agents, 2003; 22:223-227.

137. Amaral L, Fanning S and Pages JM: Efflux pumps of gramnegative bacteria: genetic responses to stress and the modulation of their activity by $\mathrm{pH}$, inhibitors, and phenothiazines. Adv Enzymol Relat Areas Mol Biol 2011; 77: 61-108.

138. Spengler G, Molnar A, Klausz G, Mandy I, Kawase M, Motohashi N and Molnar J. Inhibitory action of a new proton pump inhibitor, trifluoroketone derivative against the motility of clarithromycin-susceptible and resistant Helicobacter pylori. Int J Antimicrobial Agents 2004; 23: 631-633.

139. Molnar A, Wolfart K, Kawase M, Motohashi N and Molnar J. Effect of trifluoromethyl ketone on the motility of proton pump deficient mutant of E. coli strain and its wild-type. In Vivo 2004; 18:505-508.

140. Singh G, Wu B, Baek MS, Camargo A, Nquyen A, Slusher NA, Srinivasan R, WienerKronish JP and Lynch SV. Secretion of Pseudomonas aeruginosa type III cytotoxins is dependent on Pseudomonas quinolone signal concentration. Microb Pathog 2010; 49: 196203.

141. He YW, Wu J, Cha JS and Zhang LH. Rice bacterial blight pathogen Xanthomonas oryzae pv. oryzae produces multiple DSF-family signals in regulation of virulence factor production. BMC Microbiol 2010; 10:187.

142. Shen DK, Filopon D, Chaker H, Boullanger S, Derouazi M, Polack B and Toussaint B. High-cell-density regulation of the Pseudomonas aeruginosa type III secretion system: implications for tryptophan catabolites. Microbiology 2008; 154(8):2195-208.

143. Drew D, Klepsch MM, Newstead S, Flaig R, De Gier JW, Iwata S and Beis K. The structure of the efflux pump AcrB in complex with bile acid. Mol Membr Biol 2008; 25:67782. 
144. Nikaido E, Yamaguchi A and Nishino K. AcrAB multidrug efflux pump regulation in Salmonella enterica serovar Typhimurium by RamA in response to environmental signals. $\mathbf{J}$ Biol Chem 2008; 283:24245-53.

145. Rosenberg EY, Bertenthal D, Nilles ML, Bertrand KP and Nikaido H. Bile salts and fatty acids induce the expression of Escherichia coli AcrAB multidrug efflux pump through their interaction with Rob regulatory protein. Mol Microbiol 2003; 48:1609-19.

146. Thanassi DG, Cheng LW and Nikaido H: Active efflux of bile salts by Escherichia coli. J Bacteriol 1997; 179:2512-2518.

147. Dong YH, Gusti AR, Zhang Q, Xu JL, Zhang LH. Identification of quorum-quenching $\mathrm{N}$-acyl homoserine lactonases from Bacillus species. Appl Environ Microbiol 2002; 68:17541759.

148. Xavier KB, Bassler BL. Interference with AI-2-mediated bacterial cell-cell communication. Nature 2005; 437:750-753.

149. Shiner EK, Terentyev D, Bryan A, Sennoune S, Martinez-Zaguilan R, Li G, Gyorke S, Williams SC, Rumbaugh KP. Pseudomonas aeruginosa autoinducer modulates host cell responses through calcium signalling. Cell Microbiol 2006; 8:1601-1610.

150. Lin YH, Xu JL, Hu J, Wang LH, Ong SL, Leadbetter JR, Zhang LH. Acyl-homoserine lactone acylase from Ralstonia strain XJ12B represents a novel and potent class of quorumquenching enzymes. Mol Microbiol. 2003; 47:849-860.

151. Kaplan F, Badri DV, Zachariah C, Ajredini R, Sandoval FJ, Roje S, Levine HLF, Robinette SL, Alborn HT. Bacterial attraction and quorum sensing inhibition in Caenorhabditis elegans exudates. Journal of Chemical Ecology 2009; 35:878-892.

152. Draganov DI, Teiber JF, Speelman A, Osawa Y, Sunahara R, Ladu BN. Human paraoxonases are lactonases with overlapping and distinct substrate specificities. J Lipid Res. $2005 ; 46: 1239-1247$. 
153. Giskov MR, Manefield M, Gram L, Maximilien R, Eberl L, Molin S, Steinberg PD, Kjelleberg S. Eukaryotyc interference with homoserine lactone-mediated prokaryotic signalling. J Bacteriol 1996; 178:6618-6622.

154. Ahmer BM. Cell-to-cell signalling in Escherichia coli and Salmonella enterica. Mol Microbiol 2004; 52:933-945.

155. Yao Y, Martinez-Yamount MA, Dickerson TJ, Brogan AP. Structure of the Escherichia coli quorum sensing protein SdiA: Activation of the following switch by acyl homoserine lactones. J Mol Biol 2006; 355:262-273.

156. Duan F, March JC. Interrupting Vibrio cholerae infection of human epithelial cells with engineered commensal bacterial signaling. Biotechnol. Bioeng. 2008; 101:128 -134. 


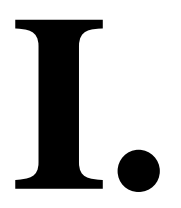




\title{
SHORT COMMUNICATION Inhibition of Quorum-sensing Signals by Essential Oils
}

\author{
Mira Ágnes Szabó ${ }^{1}$, Gábor Zoltán Varga ${ }^{1}$, Judit Hohmann², Zsuzsanna Schelz ${ }^{1}$, \\ Ernố Szegedi ${ }^{3}$ Leonard Amaral ${ }^{4}$ and József Molnár ${ }^{1}$ \\ ${ }^{1}$ Department of Medical Microbiology, Faculty of Pharmacy, University of Szeged, Hungary. \\ ${ }^{2}$ Department of Pharmacognosy, Faculty of Pharmacy, University of Szeged, Hungary. \\ ${ }^{3}$ Corvinus University of Budapest, Research Institute for Viticulture and Enology, Kecskemét, Hungary. \\ ${ }^{4}$ Unit of Mycobacteriology, UPMM, Instituto de Higiene e Medicina Tropical, Universidade de Lisboa, Lisboa, Portugal.
}

\begin{abstract}
The role of quorum sensing (QS) is well known in microbial pathogenicity and antibiotic resistance. QS is responsible for motility, swarming, and biofilm production based on the signal molecules, e.g., acylated homoserine lactones (AHLs) produced by micro-organisms above certain population density. The inhibition of QS may reduce pathogenicity, antibiotic resistance and biofilm formation in systemic and local infections. The homoserine lactones and other transmitters contribute to antibiotic resistance and pathogenicity of several bacteria; consequently the inhibition of QS signals reduces the problem of resistance and virulence. Due to the increasing number of persistent non-treatable infections, there is an urgent need to develop new strategies to combat infections that destabilize bacterial communities in the host.

The effect of essential oils on bacterial growth and QS were evaluated using the sensor strain Chromobacterium violaceum CV026 and $N$-acyl homoserine lactone (AHL) producing Escherichia coli ATTC 31298 and the grapevine colonizing Ezf 10-17 strains. Of the tested oils, rose, geranium, lavender and rosemary oils were the most potent QS inhibitors. Eucalyptus and citrus oils moderately reduced pigment production by CV026, whereas the chamomile, orange and juniper oils were ineffective. Copyright (c) 2009 John Wiley \& Sons, Ltd.
\end{abstract}

Keywords: antibiotic resistance; Chromobacterium violaceum CV026; rose oil; geranium oil; natural compounds; rosemary oil.

\section{INTRODUCTION}

Intercellular communication among bacterial cells resulting in coordinated gene expression that leads to a 'community-behavour' of bacteria is a rather common phenomenon in nature. The process itself depends on cell density, thus it has been called 'quorum sensing' (QS). Among others, N-acyl homoserine lactones (AHLs) are the most common mediators and are autoinducers of QS-regulated gene expression in bacteria. The specificity of AHLs is determined by the length of the acyl chain and the substitution $(-\mathrm{H},-\mathrm{OH}$ or $=\mathrm{O})$ on the 3 carbon position. This regulatory system consists of two genes: one produces the inducer homoserine lactones (usually designated luxI type genes) and the other codes for the luxR type receptor protein (Williams, 2007; Braeken et al., 2008; Case et al., 2008).

Cell-density-dependent regulation of bacterial genes has significant importance in several ecological relationships in plant and human pathology, as well as in the communication between prokaryotes and eukaryotes (von Bodman et al., 2003; 2008; Braeken et al., 2008: Hughes and Sperandino, 2008). Manipulation of QS may also be an efficient tool for modification of microbial communities, for improved plant protection strategies and for curing human bacterial diseases (Hentzer and Givskov, 2003; Cui and Harling, 2005; Waters and

\footnotetext{
* Correspondence to: Prof. Dr J Molnar, Institute of Medical Microbiology, University of Szeged, H-6720 Szeged, Dom tér 10, Hungary.

E-mail: molnarj@comser.szote.u-szeged.hu
}

Bassler, 2005; González and Keshavan, 2006; Scott et al., 2006; Williams, 2007).

In the case of plant pathogens, the QS in agrobacteria is one of the best studied auto-inductive signal transfer systems. Agrobacterium tumefaciens produces only one single AHL, N-3-oxo-octanoyl-L-homoserine lactone that contributes to conjugative plasmid transfer and increases copy number of the tumor inducing plasmid pTi (Li and Farrand, 2000; Pappas and Winans, 2003). The grapevine pathogen Agrobacterium vitis produces several types of AHLs coded by chromosomal or plasmid genes but their functions have not been completely determined. The chromosomal AHLs contribute to tissue necrosis and hypersensitive reactions of grapevines and tobacco, respectively ( $\mathrm{Li}$ et al., 2005; Hao and Burr, 2006). Besides these, the role of QS regulation is well documented in several additional plant-bacterial interactions (Lithgow et al., 2001; Molina et al., 2005; Quinones et al., 2005; Braeken et al., 2006; 2008).

Besides plant pathology, QS plays a key impotant role in several human diseases. Pseudomonas aeruginosa-related diseases are the most studied (Hentzer and Givskov, 2003; Rasmussen et al., 2005; Ishida et al.,2007). Manipulations of the QS system may open new possibilities and improve therapies for chronic bacterial and other diseases (Hentzer and Givskov, 2003; Rasmussen et al., 2005; Ishida et al., 2007) inluding cancer (Li et al., 2004; Shiner et al., 2006; Hickson et al., 2009). Our main aim was to construct a model for investigation of QS signal transmission regulation by using natural compounds such as essential oils. 


\section{MATERIAL AND METHODS}

Essential oils. Rose (Rosa damascena L., Rosaceae), lavender (Lavandula angustifolia L., Labiatae), chamomile (Matricaria recutica L., Asteraceae), orange (Rutaceae), eucalyptus (Eucalyptus globulus L., Myrtaceae), geranium (Geranium robertianum L., Geraniaceae), juniper (Juniperus communis L., Cupressaceae), citrus (Citrus sinensis L., Rutaceae) and rosemary oils (Rosmarinus officinalis L., Lamiaceae) were purchased from Phoenix Pharma Ltd. (Hungary, Budapest) in quality according to the requirements of Hungarian pharmacopoeia ( $\mathrm{Ph}$. Hg. VII.). The essential oils used in this study were either used directly (concentrated) or dissolved in dimethyl sulfoxyde (DMSO) to yield a dilution of $10 \%(\mathrm{v} / \mathrm{v})$. This stock solution was either used as it is or further diluted with $10 \%$ DMSO. Acridine orange was purchased from Reanal (Budapest, Hungary) and 5-Fluorouracil purchased from Sigma-Aldrich (Budapest, Hungary). Both compounds were dissolved in distilled water.

Bacterial strains. To detect auto-inducer production of tested bacteria, the biosensor strain Chromobacterium violaceum CV026 (obtained from Prof. Thomas J. Burr, Cornell University, Geneva, NY) was used. This Tn5 mutant strain produces the purple pigment violacein upon induction with externally added short-chain autoinducers (McClean et al., 1997) and it has been widely used for the detection of $\mathrm{N}$-acyl homoserine lactones or quorum sensing inhibitors (Lithgow et al., 2001; Molina et al., 2003; McClean et al., 2004). Escherichia coli ATTC 31298 and the partially characterized Ezf 10/17 isolated from a grapevine crown gall tumor (Szegedi, unpublished) were used as AHL producers. Both strains induce pigmentation of CV026 and therefore they can be used to monitor AHL-induced pigment production by $C$. violaceum $\mathrm{CV} 026$.

Culture medium. An MIC equivalent inoculum from each bacterial overnight culture were streaked on agar modified Luria Bertani (LB) agar plates containing yeast extract $(1 \mathrm{~g} / \mathrm{l})$, tryptone $(10 \mathrm{~g} / \mathrm{l}), \mathrm{NaCl}(10 \mathrm{~g} / \mathrm{l})$, K2HPO4 (1 g/l), MgSO 4 × 7H2O ( 0,3 g/l), FeNaEDTA $(36 \mathrm{mg} / \mathrm{l})$ and agar $(20 \mathrm{~g} / \mathrm{l}) . \mathrm{pH}$ was adjusted to 7.15 . Cultures were grown at $25^{\circ} \mathrm{C}$ for $48 \mathrm{~h}$.

Agar diffusion. Pair combinations of the sensor strain CV026 and the producer strains ATTC 31298 or Ezf 10-17 each at an MIC equivalent inoculum were swabbed on LB plates as approx. $5 \mathrm{~cm}$ line cultures at a $5 \mathrm{~mm}$ distance from each other. Whatman 3MM filter paper discs, $7 \mathrm{~mm}$ in diameter, impregnated with $10 \mu \mathrm{l}$ of concentrated or DMSO-diluted oils and placed on the inoculated line cultures. Discs containing acridine orange and 5-fluoro-uracil served as positive controls and that containing DMSO $(10 \mu \mathrm{l})$ served as the negative control. Signal transmission was assessed by the effect of the agent present on the disc that did not affect the development of purple colour defined as 'No QS inhibitory activity' and by the absence of colour and the size of the colourless zone defined as 'QS activity' after 24- and 48-h incubation periods.

The diameter of the reduced bacterial growth around the filter paper discs in $\mathrm{mm}$ yields the degree of the antibacterial effect of the tested compounds. Drug-free DMSO blanks served as controls for any effect produced by the DMSO diluent.

\section{RESULTS AND DISCUSSION}

The agar diffusion method provides a convenient and semi-quantitative method to assess the antibacterial activities and QS signal production in the presence of essential oils. Using this method we tested 9 essential oils compared to the positive controls of acridine orange and 5-fluoro-uracil. Most of these oils are known as inhibitors of bacterial growth (Schelz et al., 2006). Our present data demonstrate that several plant-derived essential oils not only inhibit bacterial growth but also block QS regulation processes.

As evident from Fig. 1, DMSO did not effect bacterial growth or AHL-induced violacein production. As demostrated by Fig. 2, the positive controls 5-fluoro-uracil and acridine orange produced the anticipated inhibition of QS. However, the inhibitory activity of 5FU is considerably greater than that produced by acridine orange.

The use of impregnated disks with DMSO containing various essential oils afforded an understanding of which oils inhibited the sensor response of Chromobacterium violaceum CV026 to AHL released by the bacteria employed in this study. As examples, although the geranium oil was most effective as an inhibitor of the QS response of Chromobacterium violaceum CV026 (Fig. 3A) following induction by the strains ATTC 31298 and Ezf 10-17, rose oil also has significant inhibitory activity on QS responses (Fig. 3B). Rose, lavender

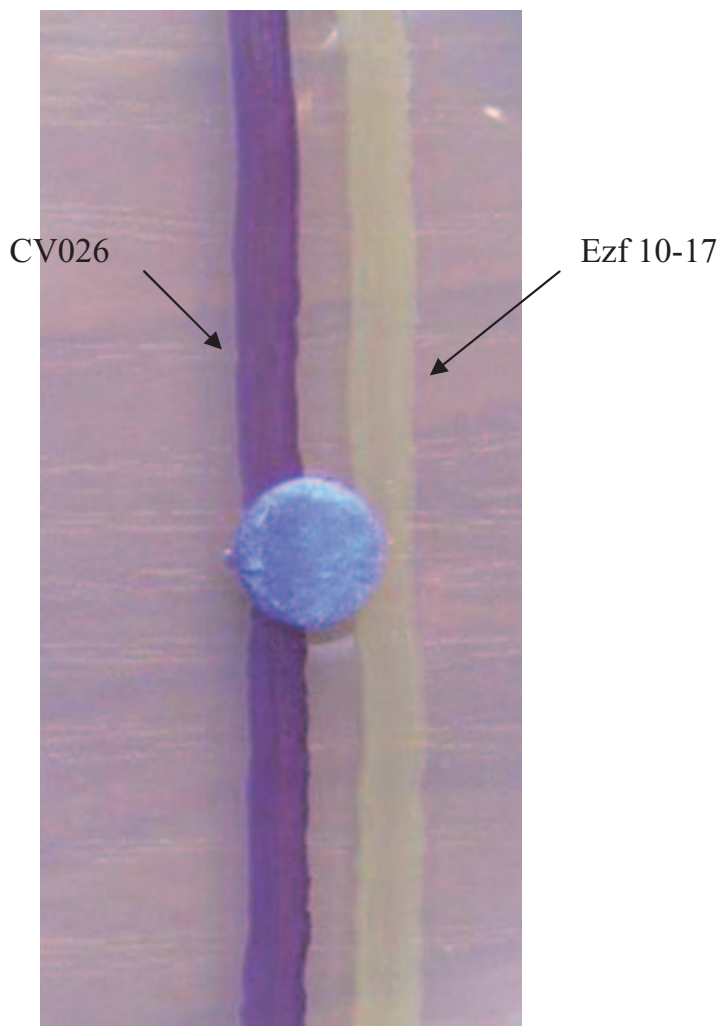

Figure 1. Negative control: DMSO does not affect colour production by the QS sensor Chromobacterium violaceum CV026 in response to an $\mathrm{AHL}$ producing bacterium. Control demonstrating color production by the $\mathrm{CV}$ responding strain and that $10 \mu \mathrm{l}$ DMSO does not affect this response. 

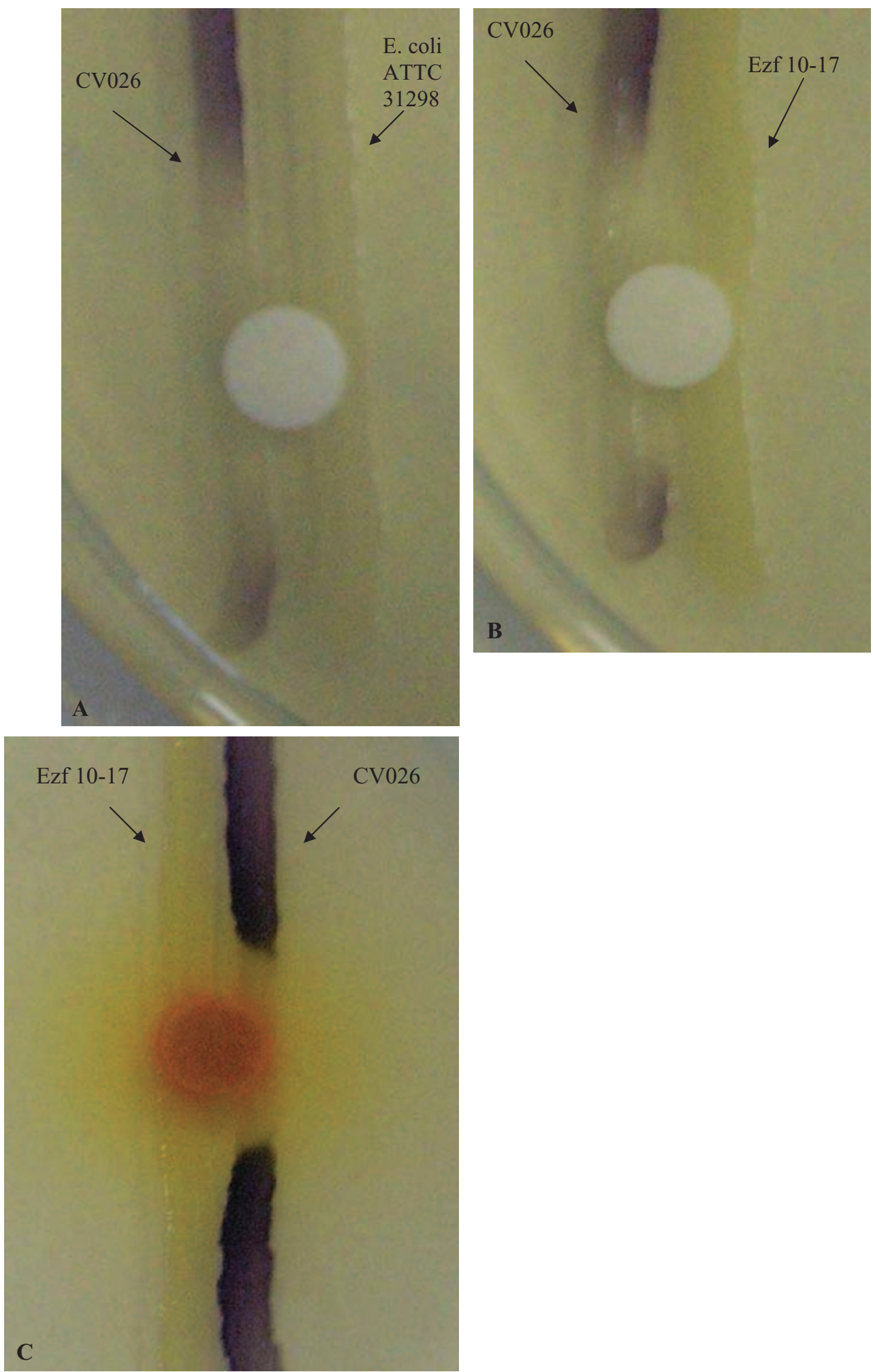

Figure 2. Positive controls: Impregnated disks with acridine orange and 5-FU inhibit the production of color by Chromobacterium violaceum CV026 in response to the AHL producing bacterium. (A) 5-FU inhibits colour response by CV 026 to the AHL produced by E. coli ATTC 31298. (B) 5-FU inhibits colour production by CV 026 to the AHL produced by Ezf 10-17. (C) Acridine orange inhibits response of CV026 to AHL produced by Ezf 10-17. Comparison of the degree of response to that affected by 5FU indicates that acridine orange has a lower inhibitory effect than 5FU.

and rosemary oils also inhibited colour development to varying degrees (Table 1). Eucalyptus oil inhibited violacein production only after induction with ATTC 31298 while citrus oil reduced colour formation only in the CV026 + Ezf 10-17 combination. As expected they also inhibited bacterial growth to variable degrees (data not shown). The other tested essential oils also had a weak antibacterial activity on C. violaceum $\mathrm{CV} 026$ but the growth of the AHL producing bacteria were not affected (data not shown). QS was moderately inhibited by lavender, eucalyptus and citrus oils, while the chamomile, orange and juniper oils were ineffective (Table 1).

The role of QS is well known in plant pathology; however it also plays an important role in several human 


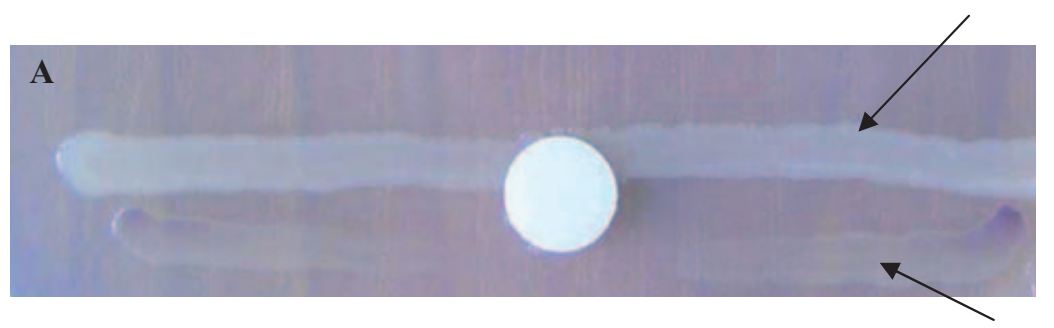

CV026

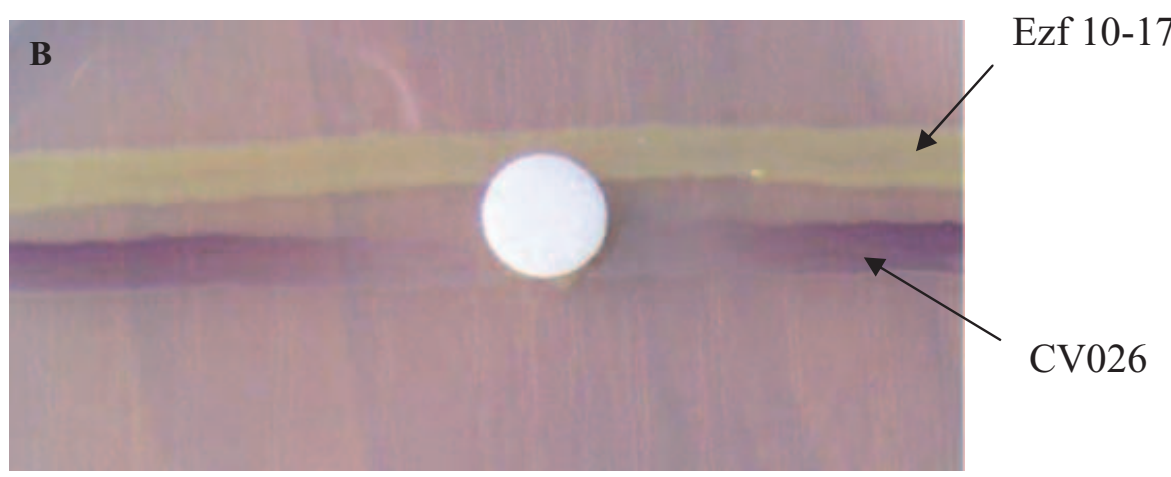

Figure 3. Demonstration of the QS inhibitor activity of essential oils. (A) Effect of Geranium oil on QS. The disc contains $10 \mu \mathrm{I}$ Geranium oil. (B) Effect of Rose oil on QS. The disc contains $10 \mu \mathrm{l}$ Rose oil.

Table 1. Effect of tested essential oils on quorum sensing signal production between Chromobacterium violaceum CV026 as sensor, and Escherichia coli ATTC 31298 and Ezf 10-17 as producer strains after 48 hr incubation

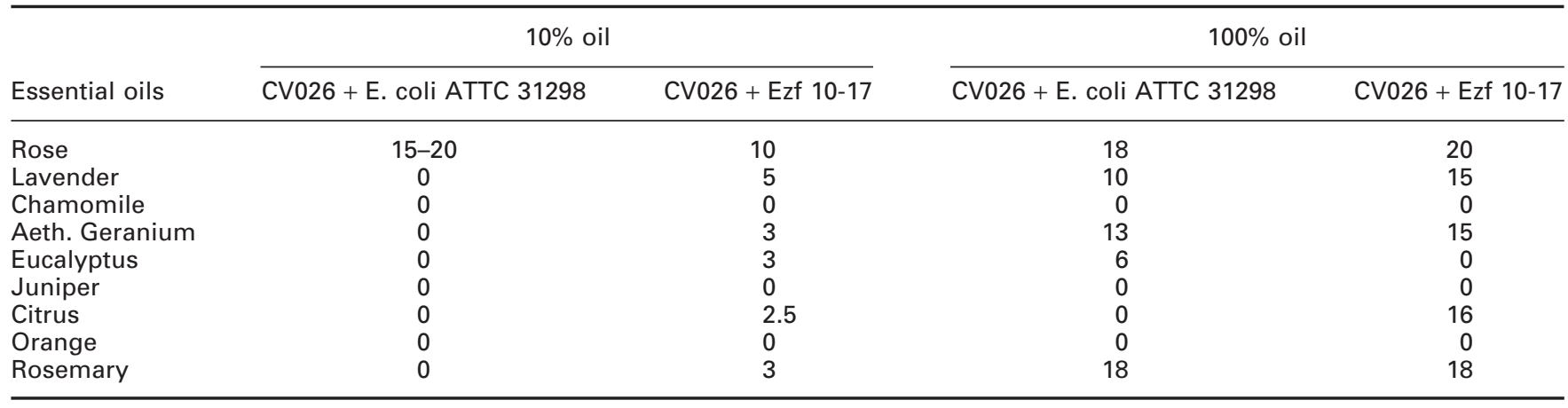

diseases. To cure bacterial diseases through the manipulation of QS-regulated processes, several natural and synthetic compounds have already been tested (Rasmussen et al., 2005; Ishida et al., 2007). The results obtained in our study show that some essential oils can also inhibit QS. Although at this time we are not suggesting that these compounds be used for the modification of QS in bacterial populations of a host, we do suggest that because these compounds modify QS at least in the laboratory environment, that the approaches employed in our study may eventually lead to a new form of therapy for some mixed human infections which, at this time, are problematic for therapy. (Hentzer and Givskov, 2003; Rasmussen et al., 2005; Ishida et al., 2007) including cancer (Shiner et al., 2006).

\section{Acknowledgements}

Authors acknowledge the skillful technical assistance of Anikó Várady Vigyikán and Marianna Ábrahám (Institute of Medical Microbiology and Immunobiology, University of Szeged, Hungary). This work was supported by the Foundation of Anticancer Research of Szeged. E. Szegedi was granted by the Hungarian National Scientific Foundation (OTKA) Grant No. K-68053.

\section{REFERENCES}

Braeken K, Moris M, Daniels R, Vanderleyden J, Michiels J. 2006. New horizons for (p)ppGpp in bacterial and plant physiology. Trends Microbiol 14: 45-54.

Braeken K, Daniels R, Ndayizeye M, Vanderleyden J, Michiels J. 2008. Quorum sensing in bacteria-plant interactions. In Molecular mechanisms of plant and microbe coexistence. Soil biology 15, Nautiyal CS, Dion P (eds). Springer-Verlag: Berlin-Heidelberg; 265-289.
Case RJ, Labbate M, Kjeleberg S. 2008. AHL-driven quorumsensing circuits: their frequency and function among the Proteobacteria. ISME J 2: 345-349.

Cui X, Harling R. 2005. N-acyl-homoserine lactonemediated quorum sensing blockage, a novel strategy for attenuating pathogenicity of Gram-negative bacterial plant pathogens. Eur J Plant Pathol 111: 327338. 
González JE, Keshavan ND. 2006. Messing with bacterial quorum sensing. Microbiol Mol Biol Rev 70: 859-875.

Hao G, Burr TJ. 2006. Regulation of long-chain $\mathrm{N}$-acylhomoserine lactones in Agrobacterium vitis. J Bacteriol 188: 2173-2183.

Hentzer M, Givskov M. 2003. Pharmacological inhibition of quorum sensing for the treatment of chronic bacterial infections. J Clin Invest 112: 1300-1307.

Hickson J, Yamada SD, Berger J, Alverdy J, O'Keefe J, Bassler B, Rinker-Schaeffer C. 2009. Societal interactions in ovarian cancer metastasis: a quorum-sensing hypothesis. Clin Exp Metastasis 26: 67-76.

Hughes DT, Sperandio V. 2008. Inter-kingdom signalling: communication between bacteria and their hosts. Nat Rev Microbiol 6: 111-119.

Ishida T, Ikeda T, Takiguchi N, Kuroda A, Ohtake H, Kato J. 2007. Inhibition of quorum sensing in Pseudomonas aeruginosa by $\mathrm{N}$-acyl cyclopentylamides. Appl Environm Microbiol 73: 3183-3188.

Li P-L, Farrand SK. 2000. The replicator of the nopaline-type Ti plasmid pTiC58 is a member of the repABC family and is influenced by the TraR-dependent quorum-sensing regulatory system. J Bacteriol 182: 179-188.

Li L, Hool D, Chhabra SR, Pritchard D, Shaw P. 2004. Bacterial $\mathrm{N}$-acylhomoserine lactone-induced apoptosis in breast carcinoma cells correlated with down modulation of STAT3. Oncogene 23: 4894-4902.

Li Y, Gronquist MR, Hao G, Holden MR, Eberhard A, Scott RA, Savka MA, Szegedi E, Süle S, Burr TJ. 2005. Chromosome and plasmid-encoded $\mathrm{N}$-acyl homoserine lactones produced by Agrobacterium vitis wildtype and mutants that differ in their interactions with grape and tobacco. Physiol Mol Plant Pathol 67: 284-290.

Lithgow JK, Danino VE, Jones J, Downie JA. 2001. Analysis of $\mathrm{N}$-acyl homoserine-lactone quorum-sensing molecules made by different strains and biovars of Rhizobium leguminosarum containing different symbiotic plasmids. Plant and Soil 232: 3-12.

McClean KH, Winson MK, Fish L, Taylor A, Chhabra SR, Camara M, Daykin M, Lamb JH, Swift S, Bycroft BW, Stewart GSAB, Williams P. 1997. Quorum sensing and Chromobacterium violaceum: exploitation of violacein production and inhibition for the detection of $\mathrm{N}$-acyl homoserine lactones. Microbiology 143: 3703-3711.

McClean RJC, Pierson LS and Fuqua C. 2004. A simple screening protocol for the identification of quorum signal antagonists. J Microbiol Meth 58: 351-360.
Molina L, Constantinescu F, Michel L, Reimman C, Duffy B, Défago G. 2003. Degradation of pathogen quorum-sensing molecules by soil bacteria: a preventive and curative biological control mechanism. FEMS Microbiol Ecol 45: 71-81.

Molina L, Rezzonico F, Défago G, Duffy B. 2005. Autoinduction in Erwinia amylowora: Evidence of an acyl-homoserine lactone signal in the fire blight pathogen. $J$ Bacteriol 187: 3206-3213.

Pappas KM, Winans SC. 2003. A Lux-R type regulator from Agrobacterium tumefaciens elevates $\mathrm{Ti}$ plasmid copy number by activating transcription of plasmid replication genes. Mol Microbiol 48: 1059-1073.

Quinones B, Dulla G, Lindow SE. 2005. Quorum sensing regulates exopolysaccharide production, motility, and virulence in Pseudomonas syringae. Mol Plant-Microbe Interact 18: 682-693.

Rasmussen TB, Bjarnsholt $T$, Skindersoe $M E$, Hentzer $M$, Kristoffersen P, Köte M, Nielsen J, Eberl L, Givskov M. 2005. Screening for quorum sensing inhibitors (QSI) by use of a novel genetic system, the QSI selector. J Bacteriol 187: 1799-1814.

Schelz Z, Molnar J, Hohmann J. 2006. Antimicrobial and antiplasmid activities of essential oils. Fitoterapia 77: 279285.

Scott RA, Weil J, Le PT, Williams P, Fray RG, von Bodman SB, Savka MA. 2006. Long- and short-chain plant-produced bacterial $\mathrm{N}$-acyl-homoserine lactones become components of phyllosphere, rhizosphere, and soil. Mol Plant-Microbe Interact 19: 227-239.

Shiner EK, Terentyev D, Bryan A, Sennoune S, MartinezZaguilan R, Li G, Gyorke S, Williams SC, Rumbaugh KP. 2006. Pseudomonas aeruginosa autoinducer modulates host cell responses through calcium signalling. Cell Microbiol 8: 1601-1610.

von Bodman SB, Bauer WD, Coplin DL. 2003. Quorum sensing in plant-pathogenic bacteria. Annu Rev Phytopathol 41: 455-482.

von Bodman SB, Willey JM, Diggle SP. 2008. Cell-cell communication in bacteria: united we stand. J Bacteriol 190: 4377-4391.

Waters CM, Basler BL. 2005. Quorum-sensing: cell-to-cell communication in bacteria. Annu Rev Cell Dev Biol 21: 319-346.

Williams P. 2007. Quorum sensing, communication and crosskingdom signalling in the bacterial world. Microbiology 153: 3923-3938. 
II. 


\title{
Quorum Sensing Inhibition by Phenothiazines and Related Compounds
}

\author{
Zoltán Gábor Varga ${ }^{1}$, Mira Ágnes Szabó ${ }^{1}$, Zsuzsanna Schelz ${ }^{1}$, Ernő Szegedi ${ }^{2}$, Leonard Amaral $^{3}$ and \\ József Molnár*,1
}

\author{
${ }^{I}$ Institute of Medical Microbiology, Faculty of General Medicine, University of Szeged, Szeged, Hungary \\ ${ }^{2}$ Corvinus University of Budapest, Research Institute for Viticulture and Enology, H-6000, Kecskemét, P. O. Box 25, \\ Hungary \\ ${ }^{3}$ Unit of Mycobacteriology/UPMM, Institute of Hygiene and Tropical Medicine, Universidade Nova de Lisboa, Portugal \\ Received March 23, 2010: Revised August 16, 2010: Accepted September 02, 2010
}

\begin{abstract}
A quorum is the smallest number of people able to organize the decisions concerning functional activity. Similarly microbes use chemical signal molecules to make population size-dependent "decisions" by changing their gene regulations.

The inhibition of quorum sensing (QS) by phenothiazines and structurally related molecules, e.g. amitriptyline, promethazine, acridine orange, imipramine, promazine, diethazine, desipramine, desertomycin and 5-fluorouracil as positive control was studied with Chromobacterium violaceum 026 as a sensor strain, which detects short carbon chain AHLs by the development of a purple pigment. The AHL was produced by Novospingobium Ezf 10-17, and the antibiotic-resistant clinical isolates, E. coli 31298.

The QS was demonstrated as a signal transmission between the two bacterial strains. The most effective inhibitors of QS were amitriptyline, promethazine, acridine orange and desertomycin. Imipramine and diethazine were moderately active, while chlorprothixene was ineffective relative to 5-fluorouracil as positive control. The direct complex formation between AHL and QS inhibitors markedly reduced the QS in a chromogenic test. The AHL-neutralizing effect of the related compounds was shown by chromogenic method.

The inhibition of QS signal transmission appears to be related to the quasi-planar structure and electron donor capacity of the conjugated $\pi$-electron system of the tricyclic framework. The results can be exploited in rational drug design as a new way to reduce the QS mediated processes eg. virulence of pathogens, to vary the formation of biofilms and to modify antibiotic resistance.
\end{abstract}

Keywords: 5-Fluorouracil, Amitriptyline, Homoserine lactone complexes, Imipramine, Promethazine, Quorum quenching.

\section{INTRODUCTION}

Phenothiazines and structurally related tricyclic compounds exert various effects on bacterial cells including the inhibition of growth and the reversal of antibiotic resistance [1-3].

Quorum sensing (QS) is a communication system mediated by chemical signals which depends on the population density of bacterial species within a common environment and contributes to their ability to compete and survive [4, 5]. It is common to both Gram-positive and Gram-negative bacteria and plays a role in intra- and interspecies communications, additionally allowing communications between microbes and their hosts [6]. QS is of great significance in the formation of biofilms [7], the production of virulence factors [8], the development of intrinsic antibiotic resistance [9], the facilitation of growth in a competitive environment [10] and the enhancement of motility [11]. It may also provide genetic advantages due to the promotion of conjugational gene transfer [12] and control of the competent state [13].

*Address correspondence to this author at the Institute of Medical Microbiology, University of Szeged, H-6720, Szeged, Dom ter 10. Hungary; Tel: +36 62 545114; +36 62 545115; Fax: +36 62 545113;

E-mail: molnarj@comser.szote.u-szeged.hu
The most common mediators in Gram-negative bacteria are the $N$-acyl homoserine lactones (AHLs). The specificity of the AHLs is determined by the length of the acyl chain and the substitution at C-3. The QS regulation system consists of two types of genes. The luxI-type genes produce autoinducer molecules such as AHLs, and the luxR-type genes produce their receptor proteins [14-16]. In Grampositive bacteria, various types of peptides have the same role in QS.

The bacterial interactions focused on QS between various species have not yet been studied in the presence of tricyclic compounds. Since these compounds have various effects on bacterial functions, QS signal transmission seems to be a good model for the characterization of molecular interactions between AHLs and commonly used tricyclic drugs.

The aim of our study was to investigate the effects of some phenothiazines and structurally related compounds on the QS signal transmission between the sensor strain Chromobacterium violaceum 026 and three different AHLproducing bacterial isolates.

\section{MATERIALS AND METHODS}

\section{Chemicals}

The following tricyclic compounds were used: promethazine (Pipolphen, EGIS, Hungary), amitriptyline 
Table 1. Investigation of Antibacterial Effects of Tricyclic Compounds with the Agar Diffusion Method

\begin{tabular}{|c|c|c|c|c|c|c|}
\hline \multirow[b]{2}{*}{ Tricyclic Compounds } & \multicolumn{6}{|c|}{ Growth Inhibition Zones in $\mathrm{mm}$} \\
\hline & Ezf10-17 & E. coli 31298 & $\begin{array}{c}\text { P. aeruginosa } \\
49010\end{array}$ & $\begin{array}{l}C V 026 \\
(+E z f \\
10-17)\end{array}$ & $\begin{array}{c}\text { CV026 } \\
(+ \text { E. coli. } \\
\text { 31298 })\end{array}$ & $\begin{array}{c}\text { CV026 } \\
(+P . \text { aeruginosa } \\
49010)\end{array}$ \\
\hline Acridine orange & - & - & - & - & - & - \\
\hline Amitriptyline & 8 & - & - & 9 & 10 & 12 \\
\hline Desipramine & 9 & 7 & - & 11 & 16 & 9 \\
\hline Imipramine & - & - & - & 9 & 9 & 7 \\
\hline Diethazine & 7 & - & - & 9 & 7 & 8 \\
\hline Promazine & 8 & - & - & 10 & 12 & 15 \\
\hline Promethazine & 9 & 7 & - & 11 & 15 & 10 \\
\hline Chlorprothixene & - & - & - & 7 & 7 & 7 \\
\hline
\end{tabular}

$10 \mu \mathrm{l}$ of a $25 \mathrm{mg} / \mathrm{ml}$ solution was added into the filter paper discs.

(Teperin, EGIS, Hungary), acridine orange (Reanal, Hungary), imipramine (Melipramin, EGIS, Hungary), desipramine, chlorprothixene (Truxal, Lundbeck, Denmark), promazine, diethazine (Parkazin, Rhone-Poulenc, France) and desertomycin. Stock solutions of these tricyclic compounds were prepared in distilled water at $25.0 \mathrm{mg} / \mathrm{ml}$ before use. For control experiments 5-fluorouracil (5-FU), and acridine orange were used as known inhibitors [2, 17]. Iodine deoxy uridine (IDU). N-hexanoyl-DL-homoserine lactone (SIGMA, Budapest).

\section{Bacterial Strains}

Chromobacterium violaceum 026 (CV026) served as QS sensor. $C$. violaceum is a common bacterium which lives in soil and water. When $C$. violaceum reaches a high cell density, it produces a purple pigment called violacein [18]. The CV026 sensor strain is a Tn5 mutant which alone cannot synthesize AHLs; it produces the purple pigment only in the presence of externally added inducers [19]. This strain has been used to detect a wide range of short-chain AHLs or QS inhibitors [20-22]. As AHL signal producers inducing CV026, the following strains were used: Ezf $10-17$ is an as yet unidentified grapevine crown gall tumour isolate which resembles Novospingobium sp.; Esherichia coli 31298 and Pseudomonas aureginosa 49010 were clinical strains isolated from a wound lesion and the human trachea, respectively.

\section{Quorum Sensing Tests}

A modified LB medium containing yeast extract $5 \mathrm{~g} / \mathrm{l}$; Trypton $10 \mathrm{~g} / \mathrm{l} ; \mathrm{NaCl} 10 \mathrm{~g} / \mathrm{l} ; \mathrm{K}_{2} \mathrm{HPO}_{4} 1 \mathrm{~g} / \mathrm{l} ; \mathrm{MgSO}_{4} \times 7 \mathrm{H}_{2} \mathrm{O}$ $0.3 \mathrm{~g} / \mathrm{l}$ and FeNaEDTA $36 \mathrm{mg} / \mathrm{l}$ supplemented with agar (Difco) $20 \mathrm{~g} / \mathrm{l})(\mathrm{pH} 7.2)$ was used for the experiments. The sensor strain CV026 and the AHL producer strains Ezf10-17, E. coli 31298 or $P$. aureginosa 49010 were inoculated as parallel lines and incubated at room temperature $\left(20{ }^{\circ} \mathrm{C}\right)$ for 24-48 h.

QS inhibition was monitored by the agar diffusion method. Filter paper discs $(7.0 \mathrm{~mm}$ in diameter, Whatmann $3 \mathrm{MM}$ ) were impregnated with $10 \mu \mathrm{l}$ of stock solutions of the tricyclic compounds in distilled water. The discs were placed on the surface of nutrient agar between the parallel lines of sensor and AHL producer strains. The plates were incubated at room temperature for further 24-48 $\mathrm{h}$ and the interactions between the strains and tricyclic compounds were evaluated as concerns the reduction in the size of the zone of pigment production and the size of the zone of growth inhibition of the affected strains, in $\mathrm{mm}$. 5-FU was applied as positive control [17].

\section{Evaluation of Complex Formation Between the Comercially AHL and QS Inhibitors}

Biological method: $1 \mu \mathrm{l}$ of a solution of $5,10 \mathrm{or} 25 \mathrm{ng}$ of AHL was mixed with $10 \mu \mathrm{l}$ of stock solution $(25 \mathrm{mg} / \mathrm{ml})$ of the potential QS inhibitor. Filter paper discs $(7.0 \mathrm{~mm}$ in diameter, Whatmann $3 \mathrm{MM}$ ) were impregnated with $11 \mu \mathrm{l}$ of the mixture of QS inhibitor and AHL solution. The discs were placed on the surface of nutrient agar media, upon the inoculation line of the CV026 sensor strain. The plates were incubated at room temperature $\left(18-22{ }^{\circ} \mathrm{C}\right)$ for a further $24-48$ $\mathrm{h}$ and the interactions between the AHL and the tricyclic compounds were evaluated in terms of the reduction in the diameter of pigment production (due to complex formation when the AHL was inactivated), and the reduced colour intensity.

\section{RESULTS}

The agar diffusion method provides an opportunity to investigate the potential inhibition of tricyclic compounds on QS between the QS sensor C. violaceum and three AHL producing bacteria. For control experiments, Ezf 10-17 adjacent to the QS sensor CV026 cultured in the presence of a water-containing disc resulted in the purple colouration of the swabbed sensor, an indication of a positive response to the presence of AHLs produced by Ezf 10-17. To demonstrate that the colouration of the sensor strain is prevented by a known inhibitor of the QS response, 5-FU and acridine orange were used as positive controls. Since the phenothiazines have antimicrobial activity against $E$. coli [1], the inhibition of violacein production as quorum signal was measurable only at subinhibitory concentrations on the growth of inoculated bacteria. Consequently, the production of AHL as a QS mediator was evaluated below the MICs of the phenothiazines against the AHL-producing bacteria. 
Table 2. Inhibitory Effects of Tricyclic Compounds on QS Signal Transmission

\begin{tabular}{|c|c|c|c|}
\hline \multirow{2}{*}{ Tricyclic Compounds } & \multicolumn{3}{|c|}{ QS Inhibition Zone in mm } \\
\cline { 2 - 4 } & EZF 10-17 & E. c. 31298 & 14 \\
\hline \hline Acridine orange & 14 & 12 & 60 \\
\hline Amitriptyline & 64 & 26 & - \\
\hline Desipramine & 26 & 12 & - \\
\hline Imipramine & 15 & 12 & - \\
\hline Diethazine & 18 & 13 & 20 \\
\hline Promazine & 13 & 20 & 15 \\
\hline Promethazine & 26 & - & - \\
\hline Chlorprothixene & - & & \\
\hline
\end{tabular}

$10 \mu \mathrm{l}$ of $25 \mathrm{mg} / \mathrm{ml}$ stock solution was impregnated into the filter paper discs $(25 \mu \mathrm{g} / \mathrm{disc})$ and the colourless zone around the disc measured on C. violalaceum was measured after incubation for $24-36 \mathrm{~h}$ at room temperature.

Table 3. The Effects of QS Inhihibitors on N-hexanoyl-DL-homoserine Lactone (C6 HSL) Mediated Violacein Production

\begin{tabular}{|c|c|c|c|c|}
\hline Quantity of C6 HSL & O ng (K) & $5 \mathrm{ng}$ & $10 \mathrm{ng}$ & $25 \mathrm{ng}$ \\
\hline IDU $10 \mu \mathrm{g}$ & 0 & 15 & 25 & 30 \\
\hline Desertomycin $200 \mu \mathrm{g}$ & 0 & 22 & 25 & 30 \\
\hline $5-\mathrm{FU}^{*} 30 \mu \mathrm{g}$ & 0 & 29 & 35 & 35 \\
\hline Promazine $250 \mu \mathrm{g}$ & 0 & 0 & 30 & 32 \\
\hline Imipramine $250 \mu \mathrm{g}$ & 0 & 0 & 20 & 26 \\
\hline Amitriptyline $250 \mu \mathrm{g}$ & 0 & 0 & 25 & 30 \\
\hline C6 HSL control & 0 & 25 & 34 & 35 \\
\hline
\end{tabular}

The amount of each phenothiazine placed onto the disk was chosen so that it did not produce any antimicrobial effect against the given bacterium (less than one-half of the MIC). In summary, amitriptyline, desipramine, imipramine and promethazine inhibited the production of the purple colour by the sensor CV026 strain. Although the concentration of each phenothiazine was identical, the degree of inhibition varied as the distance between the disk and the margins of the diameter of the produced colouration. Table 1 shows the antibacterial effects of the phenothiazines: the diameters of the growth inhibitory zones are indicated in mm. To study for the effects of phenothiazines and structurally related compounds on QS, the tricyclic compounds were examined in a concentration below the growth inhibitory doses. The inhibition of QS signal tranmission was measured as described in the Methods section. The production of colourless zones by the phenothiazine compounds impregnated into the filter paper discs was measured around CV026, in response to the inhibited AHLs produced by Ezf10-17, E.coli and P.aeruginosa. As shown in Table 2, the degree of inhibition of purple colour formation by CV026 in response to AHLs produced by the various bacteria differed, indicating that the effectivities of the tricyclics differed as regards the QS response on the senzor CV026.

The mechanism of QS inhibition was studied by measuring the effects of the direct interactions between the AHL and QS inhibitors on violacein production in the bioassay. The most effective inhibitors were imipramine, promethazine, desipramine and amitriptyline, which in high concentration inactivated the AHL and probably formed micellar complexes.

The activities of the complexes between AHL and its inhibitors were measured in AHL-specific chromogenic tests. The biological activities of the AHL complexes were apparently reduced by complex formation, compared with the uncomplexed control AHL (Table 3).

\section{DISCUSSION}

The effects of tricyclic compounds on various Grampositive and Gram-negative bacteria and R-plasmid elimination were examined earlier $[1,24]$, and the inhibition of horizontal plasmid transfer due to the blocked conjugation [25], antibacterial and plasmid curing in coexisting bacterial populations is known. The importance of tricyclic compounds as a class of "non-antibiotics" which may 
provide alternatives to the ineffective therapy of serious bacterial infections has already been reviewed [3]. Despite this considerable body of evidence, however the effects of tricyclic compounds on QS have not been studied before.

QS signal transmission plays a key role in several microbial processes since the inhibition of QS may modify pathogenicity, virulence and antibiotic resistance.

Obviously, if the specific QS system is blocked during the bacterial infectious process, the therapy of serious infections may be improved. In view of the demonstration that certain tricyclic compounds can block the QS signal response of diverse bacterial species, it is conceivable, that in the future these compounds may be used to modify biological signal transmission at a population level, e.g. by the modification of antibiotic resistance in biofilms, the production of virulence factors and the antibiotic production of some microbes in combination with conventional therapy to reduce the virulence of certain types of bacterial infections.

We presume that in a mixed bacterial population the partners may outcompete competitors in vivo too, consequently gaining benefit within the population. There are other practically important opportunities when QS can also be a signal, mediating messages in microorganisms and host relationships.

The effects of known QS inhibitors can be exploited to prevent or lower virulence and antibiotic resistance and the formation of biofilms on catheters. The results obtained may lead to a rational drug design with perspectives of improved chemotherapy. We assume that the inhibition of proton motive forces plays a key role in the modification of QS signal transmission.

\section{CONCLUSION}

The inhibition of quorum sensing signal transmission by the studied tricyclic compounds may open a new perspective to modify various quorum sensing mediated processes: like biofilm formation, bacterial pathogenicity and antibiotic resistance.

\section{ACKNOWLEDGEMENTS}

The authors acknowledge the skilful technical assistance of Anikó Várady Vigyikán and Marianna Ábrahám, Institute of Medical Microbiology and Immunobiology, University of Szeged, Szeged, Hungary. This work was supported by the Foundation of Anticancer Research of Szeged (http://www.szegedirakkutatasert.hu) and the COST network BM0701 - ATENS.

\section{REFERENCES}

[1] Molnár, J.; Király, J.; Mándi Y.The antibacterial action of R-factor inhibiting activity by chlorpromazine. Experientia, 1975, 31, 444445 .

[2] Szabó, M. A.; Varga, G.Z.; Hohmann, J.; Schelz, Z.; Szegedi, E.; Amaral, L.; Molnár, J. Inhibition of quorum-sensing signals by essential oils. Phytother. Res., 2010, 24(5), 782-786.

[3] Spengler, G.; Miczák, A.; Hajdú, E.; Kawase, M.; Amaral, L.; Molnár, J. Enhancement of plasmid curing by 9-aminoacridine and two phenothiazines in the presence of proton pump inhibitor 1-(2benzoxazolyl)-3,3,3-trifluoro-2-propanone. Int. J. Antimicrob. Agents, 2003, 22, 223-227.

[4] Margaret, C.; Siri, R. C.; Paul, W. A Twist in the tail and a blow for host immunity. Chem. Biol., 2008, 15(11), 1141-1147.

[5] Hooshangi, S.; Bentley, W. E. From unicellular properties to multicellular behaviour: bacteria quorum sensing circuitry and applications. Curr. Opin. Biotechnol., 2008, 19(6), 550-555.

[6] David, T. Hughes and Vanessa Sperandio: Inter-kingdom signalling: communication between bacteria and their host. Nat. Rev. Microbiol., 2008, 6(2), 111-120.

[7] Reeser, R.J.; Medler, R. T.; Billington, S. J.; Jost, B.H.; Joens, L. A. Characterization of Campylobacter jejuni biofilms under defined growth conditions. Appl. Environ. Microbiol., 2007, 73(6), 1908-1913.

[8] Ji, G.; Beavis, R.; Novick, R. P. Cell density control of staphylococcal virulence mediated by an octapeptide pheromone. Proc. Natl. Acad. Sci. USA, 1995, 92, 12055-12059.

[9] Pumbwe, L.; Skilbeck, C.A.; Wexler, H. M. Presence of Quorumsensing Systems Associated with Multidrug Resistance and Biofilm Formation in Bacteroides fragilis. Microb. Ecol., 2008, 56(3), 412 419.

[10] Liu, X.; Bimerew, M.; Ma, Y.; Müller, H.; Ovadis, M.; Eberl, L.; Berg, G.; Chernin, L. Quorum-sensing signaling is required for production of the antibiotic pyrrolnitrin in a rhizospheric biocontrol strain of Serratia plymuthica. FEMS Microbiol. Lett., 2007, 270(2), 299-305.

[11] Tian, Y.; Wang, Q.; Liu, Q.; Ma, Y.; Cao, X.; Guan, L.; Zhang, Y. Involvement of LuxS in the regulation of motility and flagella biogenesis in Vibrio alginolyticus. Biosci. Biotechnol. Biochem., 2008, 72(4),1063-1071.

[12] Dunny, G. M. The peptide pheromone-inducible conjugation system of Enterococcus faecalis plasmid pCF10: cell-cell signalling, gene transfer, complexity and evolution. Philos. Trans. R. Soc. Lond. B. Biol. Sci., 2007, 29, 362(1483):1185-1193.

[13] Tomasz, A. Control of the competent state in Pneumococcus by a hormone-like cell product: an example for a new type of regulatory mechanism in bacteria. Nature, 1965, 9, 208(5006), 155-159.

[14] Braeken, K.; Daniels, R.; Ndayizeye, M.; Vanderleyden, J.; Michiels, J. Quorum sensing in Bacteria-Plant Interactions. In: Nautiyal, C.S.; Dion, P. Eds. Molecular Mechanisms of Plant and Microbe Coexistence. Soil Biology, 2008, vol. 15, pp. 265-289. 10.1007/978-3-540-75575-3

[15] Case, R.J.; Labbate, M.; Kjeleberg, S. AHL-driven quorum-sensing circuits: their frequency and function among the Proteobacteria. The ISME Journal, 2008, 2, 345-349

[16] Williams, P. Quorum sensing, communication and cross-kingdom signalling in the bacterial world. Microbiology, 2007, 153, 39233938

[17] Attila, C.; Ueda, A.; Wood, T. K. 5-Fluorouracil reduces biofilm formation in Escherichia coli K-12 through global regulator AriR as an antivirulence compound. Appl. Microbiol. Biotechnol., 2009, 82(3), 525-533.

[18] Ballantine, J. A.; Beer, R. J. S.; Crutchley, D. J.; Dodd, G. M.; Palmer, D. R. The synthesis os violacein and related compounds. Proc. Chem. Soc., 1958, 232-233.

[19] McClean, K. H.; Winson, M. K.; Fish, L.; Taylor, A.; Chhabra S.R.; Camara, M. Daykin, M.; Lamb, J. H.; Swift, S.; Bycroft, B.W.; Stewart, G.S.A.B.; Williams, P. Quorum sensing and Chromobacterium violaceum: exploitation of violacein production and inhibition for the detection of $\mathrm{N}$-acyl homoserine lactones. Microbiology, 1997, 143, 3703-3711.

[20] Lithgow, J. K.; Danino, V. E.; Jones, J.; Downie, J. A. Analysis of $\mathrm{N}$-acyl homoserine-lactone quorum-sensing molecules made by different strains and biovars of Rhizobium leguminosarum containing different symbiotic plasmids. Plant Soil, 2001, 232, 3-12.

[21] Molina, L.; Constantinescu, F.; Michel, L.; Reimman, C.; Duffy, B.; Défago, G. Degradation of pathogen quorum-sensing molecules by soil bacteria: a preventive and curative biological control mechanism. FEMS Microbiol. Ecol., 2003, 45, 71-81.

[22] McClean, R.J.C.; Pierson, L. S.; Fuqua, C. A simple screening protocol for the identification of quorum signal antagonists. $\mathrm{J} . \mathrm{Mi}$ crobiol. Methods, 2004, 58, 351-360.

[23] Joseph, M.; Yvette, M.; Joseph, F.; Sándor, F.; Maria, M.; Noburu, M. Effect of phenothiazines, benzo $[a]$ phenothiazines, benz $[c]$ acridines and pentaglobin on endotoxin. In Vivo, 1995, 9, 463-468 
[24] Mándi, Y.; Molnár, J.; Holland, I.B.; Béládi, I. Efficient curing of an Escherichia coli F-prime plasmid by phenothiazines. Genet. Res., 1976, 26, 109-111,
[25] Mándi, Y.; Molnár, J. Effect of chlorpromazine on conjugal plasmid transfer and sex pili. Acta Microbiol. Acad. Sci. Hung., 1981, 28, 205-210. 


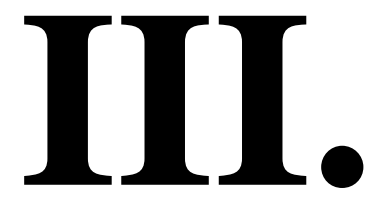




\title{
Inhibition of Quorum Sensing and Efflux Pump System by Trifluoromethyl Ketone Proton Pump Inhibitors
}

\author{
ZOLTÁN G. VARGA ${ }^{1}$, ANA ARMADA ${ }^{2}$, PEDRO CERCA $^{2}$, LEONARD AMARAL ${ }^{2 *}$, \\ MIOR A.A. MIOR AHMAD SUBKI ${ }^{3}$, MICHAEL A. SAVKA ${ }^{3}$, ERNŐ SZEGEDI ${ }^{4}$, \\ MASAMI KAWASE ${ }^{5}$, NOBORU MOTOHASHI ${ }^{6}$ and JOSEPH MOLNÁR ${ }^{1}$ \\ ${ }^{1}$ Institute of Medical Microbiology, University of Szeged, Szeged, Hungary; \\ ${ }^{2}$ Group of Mycobacteria, Unit of Microbiology and \\ ${ }^{3}$ Department of Biological and Medical Sciences, Rochester Institute of Technology, Rochester, NY, U.S.A.; \\ ${ }^{4}$ Research Institute for Viticulture and Enology, Kecskemét, Hungary; \\ ${ }^{5}$ Faculty of Pharmaceutical Sciences, Matsuyama University, Ehime, Japan; \\ ${ }^{6}$ Faculty of Pharmaceutical Sciences, Meiji Pharmaceutical University, Tokyo, Japan
}

\begin{abstract}
Background: One major microbiological problem is the widespread antibiotic resistance. There is an urgent need for new antibiotics and ways to treat multi-drugresistant infections. Inhibition of bacterial quorum sensing $(Q S)$ systems could be an effective alternative in a smuch as they regulate a broad spectrum of cell functions, including, virulence factor production, biofilm organisation and motility. Influx and efflux bacterial systems involved in quorum sensing $(Q S)$ are known to depend on the proton motive force (PMF). Thus, a new series of 12 trifluoromethyl ketones (TFs) known to inhibit the PMF, was investigated for effects on the efflux pump of a QS responding bacterium, for its subsequent effect on the response to a QS signal and its direct inhibition of the response to a QS signal. Materials and Methods: Chromobacterium violaceum 026 (CV026) was used as the indicator strain to evaluate the QS inhibitory effect of TFs. This strain responds to the presence of short carbon chain acyl-homoserine lactones (AHLs) by the development of a purple pigment. Effect on the QS response of CV026 to externally added AHLs was evaluated. In addition, the specific activity of the TFs on the efflux pump system of the CV026 strain and a wild-type Escherichia coli strain was assessed with the aid of the automated real-time
\end{abstract}

* Cost Action BM0701 of the European Commission/European Science Foundation.

Correspondence to: Professor Dr. J. Molnár, Institute of Medical Microbiology, University of Szeged, H-6720, Szeged, Dom ter 10, Hungary. Tel: $+3662545114,+3662545115$, Fax: +3662545113 , e-mail: molnarj@comser.szote.u-szeged.hu

Key Words: Quorum sensing, CV026, trifluoromethyl ketones, AHL, efflux pump. ethidium bromide method. Results: From the 12 compounds, 6 proved to be effective inhibitors of the QS response by CV026, as well as inhibit the efflux pumps of CV026 and Escherichia coli. Conclusion: Our results show that TFs have QS inhibitory properties that are mediated through their inhibition of efflux pumps that extrude the noxious QS signal before it reaches its intended target. Because the TFs also inhibit the efflux pump of a pathogenic bacterium, the method used for the evaluation of the TFs in the current study has clinical relevance and may be exploited for the prevention of $Q S$ responses of infecting bacteria.

The antimicrobial and antimotility effects of 30 trifluoromethyl ketones (TFs) on various bacterial species have already been studied (1-5). Some of these TFs only inhibit the growth of various Gram-positive bacteria, while others exhibit antimicrobial activity against Gram-negative bacteria and yeasts. The combination of certain derivatives of TFs with promethazine results in a synergistic antibacterial effect (1).

TFs at subinhibitory concentrations inhibit the motility of Proteus vulgaris. Detailed analysis demonstrated that the proportion of mobile bacterial cells is reduced (2), suggesting that the action of TFs at concentrations that have no effect on the viability of the studied bacteria involves the inhibition of an energy source upon which flagellae depend for their action, namely, the proton motive force (PMF) (2).

Quorum sensing (QS) signal systems regulate a broad spectrum of cell functions in bacterial populations (6-8). Among the functions that depend or interact with QS is the secretion of biofilms. Bacteria whose main efflux pump has been deactivated or deleted are deficient in the secretion of QS signals (9) as well as production of biofilm (10). Efflux pumps of the resistance nodulation division (RND) family of transporters, depend upon the energy provided by the PMF 
Table I. Inhibitory effects of the (TFS) on (QS) and the growth of producing and QS sensor bacterial strains, after 24 hours of incubation. The extent of the colourless zone indicates the inhibitory effect of the given compound on QS signal transmission.

\begin{tabular}{rccc}
\hline TF & \multicolumn{2}{c}{ MIC $(\mu \mathrm{g} / \mathrm{ml})$} & $\begin{array}{c}\text { Extent of QS } \\
\text { inhibition [zone of } \\
\text { discolouration) } \\
\text { at } 20 \mu \mathrm{g} / \text { disc }(\mathrm{mm})]\end{array}$ \\
\cline { 2 - 3 } CV026 & EZF 10-17 & 26 \\
$\mathbf{1}$ & 50 & 25 & 28 \\
$\mathbf{2}$ & 12.5 & 25 & 30 \\
$\mathbf{3}$ & 12.5 & 12.5 & 20 \\
$\mathbf{4}$ & 50 & 50 & 16 \\
$\mathbf{5}$ & 50 & 50 & 0 \\
$\mathbf{6}$ & $>200$ & $>200$ & 0 \\
$\mathbf{7}$ & $>200$ & $>200$ & 0 \\
$\mathbf{8}$ & $>200$ & $>200$ & 29 \\
$\mathbf{9}$ & 50 & 25 & 0 \\
$\mathbf{1 0}$ & $>200$ & $>200$ & 0 \\
$\mathbf{1 1}$ & $>200$ & $>200$ & 0 \\
$\mathbf{1 2}$ & $>200$ & $>200$ & 0 \\
\hline
\end{tabular}

CV026: Chromobacterium violaceum 026

for effective function $(11,12)$. These efflux pumps extrude noxious agents that penetrate the outer cell wall of the organism prior to reaching their intended targets (13). QS signals that are produced by one species for the inhibition of growth of a competing bacterial species can be considered noxious agents; consequently one would expect that compounds shown to inhibit access to energy provided by the PMF would have a negative effect on the main efflux pump of the responding competitor and hence the response to a QS signal such as $N$-acyl homoserine lactone (AHL) would be negatively affected. Since TFs have been shown to affect access to energy provided by the PMF (5) we have been studying the effects of a series of 12 systematically synthesized TFs (1-12) (Table I) on the QS signal system. This study evaluated the effect of 12 TFs on the expression of the AHL-mediated signal in a system containing the environmental member Sphingomonas sp. Ezf 10-17 strain, as producer of AHL and the Chromobacterium violaceum CV026 as the responding sensor to AHL. Since the effects of the TFs on the QS system by the former system do not distinguish an effect on the producer versus the responder, the effects of the TFs on the responder were directly assessed by combinations of pure commercial $\mathrm{N}$-Hexanoyl-DLhomoserine lactone AHLs and each TF. In addition, we have studied the effects of the TFs on the activity of the efflux pumps of the QS-responding CV026 strain, as well as on the efflux pump system of Escherichia coli, in order to determine the role that an efflux pump system might play in the response to a QS signal.<smiles>[R]Cc1cc2cc([R])c([R])cc2nc1C[R]</smiles>

\begin{tabular}{lllll}
$\mathrm{TF}$ & $\mathrm{R}^{1}$ & $\mathrm{R}^{2}$ & $\mathrm{R}^{3}$ & $\mathrm{X}$ \\
\hline $\mathbf{1}$ & $\mathrm{H}$ & $\mathrm{H}$ & $\mathrm{CF}_{3}$ & $\mathrm{O}$ \\
$\mathbf{2}$ & $\mathrm{Cl}$ & $\mathrm{H}$ & $\mathrm{CF}_{3}$ & $\mathrm{O}$ \\
$\mathbf{3}$ & $\mathrm{F}$ & $\mathrm{H}$ & $\mathrm{CF}_{3}$ & $\mathrm{O}$ \\
$\mathbf{4}$ & $\mathrm{CH}_{3}$ & $\mathrm{H}$ & $\mathrm{CF}_{3}$ & $\mathrm{O}$ \\
$\mathbf{5}$ & $\mathrm{CH}_{3} \mathrm{O}$ & $\mathrm{H}$ & $\mathrm{CF}_{3}$ & $\mathrm{O}$ \\
$\mathbf{6}$ & $\mathrm{Ph}$ & $\mathrm{H}$ & $\mathrm{CF}_{3}$ & $\mathrm{O}$ \\
7 & $\mathrm{COOC}_{2} \mathrm{H}_{5}$ & $\mathrm{H}$ & $\mathrm{CF}_{3}$ & $\mathrm{O}$ \\
$\mathbf{8}$ & $\mathrm{H}$ & $\mathrm{COOC} \mathrm{H}_{5}$ & $\mathrm{CF}_{3}$ & $\mathrm{O}$ \\
9 & $\mathrm{H}$ & $\mathrm{H}$ & $\mathrm{CClF}_{2}$ & $\mathrm{O}$ \\
10 & $\mathrm{H}$ & $\mathrm{H}$ & $\mathrm{CH}_{3}$ & $\mathrm{O}$ \\
$\mathbf{1 1}$ & $\mathrm{H}$ & $\mathrm{H}$ & $\mathrm{CF}_{3}$ & $\mathrm{NH}$ \\
12 & $\mathrm{H}$ & $\mathrm{H}$ & $\mathrm{CF}_{3}$ & $\mathrm{~S}$ \\
\hline
\end{tabular}

Figure 1. Structures of trifluoromethyl ketones investigated in this study.

\section{Materials and Methods}

Chemicals. Eleven TFs (1-9, 11 and 12) were synthesized by reaction of the corresponding 2-methylbenzazoles with trifluoroacetic or chlorodifluoroacetic anhydride (14). Compound 10 was prepared by treatment of 2-lithiomethylbenzoxazole with ethyl acetate $(15,16) . N$-Hexanoyl-DL-homoserine lactone was purchased from Sigma (Budapest, Hungary). TFs were dissolved in, dimethyl sulfoxide (DMSO).

The structures of the TFs are presented in Figure 1. Ethidium bromide and thioridazine were purchased from Sigma (Madrid, Spain).

Bacterial strains. Chromobacterium violaceum is a common bacterium which lives in soil and water. When it attains a high cell density, it produces a purple pigment called violacein (17). The $C$. violaceum CV026 used as a sensor strain to study the effect of TFs on QS is a Tn5 mutant that cannot synthesize AHLs; it produces the purple pigment only in the presence of externally added inducers (18). This strain has been used to detect a wide range of short-chain AHL molecules and QS inhibitors (19-21). Ezf 10-17 was isolated from a grapevine crown gall tumor. This strain induced pigment production by CV026 and proved to be efficient to study QS interactions (22). Escherichia coli wild-type AG100 [argE3 thi-1 rpsL xyl mtl (gal-uvrB) supE44] was employed for the determination of effects of TFs on the activity of the intrinsic efflux pump of this organism (13).

Medium. A modified LB agar containing yeast extract $5 \mathrm{~g}$, trypton $10 \mathrm{~g}, \mathrm{NaCl} 10 \mathrm{~g}, \mathrm{~K}_{2} \mathrm{HPO}_{4} 1 \mathrm{~g}, \mathrm{MgSO}_{4} \bullet 7 \mathrm{H}_{2} \mathrm{O} 0.3 \mathrm{~g}$ and FeNaEDTA $36 \mathrm{mg}$ in 1.0 liter of distilled water was used to study the effect of TFs of QS. Ezf 10-17 was grown on potato dextrose agar (PDA) to prepare signal compounds. E. coli was cultured on Mueller-Hinton broth (MHB) and colonies isolated on Mueller-Hinton agar (MHA) purchased in powder form from Sigma (Madrid, Spain). 
Taxonomic identification of Ezf10-17 and analysis of its AHL production. The V3 region of $16 \mathrm{~S}$ rDNA from Ezf 10-17 was amplified using the forward primer (5'-ACTCCTACGGGAGGCA GCAG-3') and reverse primer (5'-ATTACCGCGGCTGCTGG-3') and sequenced. Sequence data were compared and analysed by BLAST against the published 16S V3 sequences available in the database.

The AHLs from the liquid culture of Ezf 10-17 were extracted and concentrated by using acidified ethyl acetate liquid-liquid extraction. The purified AHLs were analysed using thin layer chromatography (TLC) overlaid with $C$. violaceum $\mathrm{CV} 026$ biosensor strain.

Evaluation of the effect of TFs on the response by CV026 to AHL. Isolated colonies of the AHL-responding CV026 were plated directly as a 6 to $7 \mathrm{~cm}$ line on the surface of the modified LB agar. One microlitre of solution containing 5 or $10 \mathrm{ng}$ of $\mathrm{N}$-Hexanoyl-DLhomoserine lactone AHLs was mixed with $10 \mu \mathrm{l}$ of the stock $(2 \mathrm{mg} / \mathrm{ml}$ or $0.4 \mathrm{mg} / \mathrm{ml}$ ) solution of the potential QS inhibitor TF compound. Filter paper discs $(7.0 \mathrm{~mm}$ in diameter $)$ were impregnated with $11 \mu \mathrm{l}$ of the mixture of different concentrations of each TF and AHL, and the disks were placed on the inoculated line of the CV026 sensor strain (18). For sets of assays that aimed to evaluate the interaction between AHL and each TF, blank filter disks were separately impregnated with $11 \mu \mathrm{l}$ of AHL alone, with $11 \mu \mathrm{l}$ each of the TFs alone, and with $11 \mu \mathrm{l}$ of DMSO, the latter serving as an absolute control. The plates were incubated at room temperature $\left(\mathrm{ca} .20^{\circ} \mathrm{C}\right)$ for $24-48 \mathrm{hs}$.

Minimum inhibitory concentration (MIC) of each TF on CV026 and E. coli AG100. The MIC of TFs was determined by the broth dilution method according to Clinical and Laboratory Standards Institute (CLSI) guidelines (23).

Assessment of the effects of each TF on the activity of the efflux pump systems of CVO26 and Escherichia coli AG100. The activity of the TFs on the real-time accumulation of ethidium bromide (EB) was assessed by the automated EB method, previously described in detail (24), using the Rotor-Gene $3000^{\mathrm{TM}}$ thermocycler with realtime analysis software (Corbett Research, Sydney, NSW, Australia). Briefly, E. coli AG100 was cultured in MHB medium until the culture reached an optical density (OD) of 0.6 at $600 \mathrm{~nm}$, the culture was then centrifuged at 13,000 rpm for $3 \mathrm{~min}$, the pellets were resuspended in phosphate-buffered saline (PBS; $\mathrm{pH}$ 7.4) with a final concentration of glucose of $0.4 \%$ and the OD adjusted to 0.6 at 600 $\mathrm{nm}$. Aliquots of $45 \mu \mathrm{l}$ of the cell suspension were distributed to 0.2 $\mathrm{ml}$ tubes. The TFs were individually added at concentrations equal to half their MIC against the strain in $5 \mu$ l volumes of their stock solutions, and finally $45 \mu \mathrm{l}$ of EB to yield a final concentration of 1 $\mathrm{mg} / \mathrm{l}$ (Sigma-Aldrich) in PBS, with and without glucose, were added. Note that the selection of a concentration of each $\mathrm{TF}$ at half its MIC is due to the empirical fact that at this concentration there is no significant effect on the viability of the organism $(24,25)$. It is also important to note that prior to the experiments described, the maximum concentration of EB which was within the capacity of the bacterium to extrude, was determined at least three times. For the wild-type E. coli AG100 reference and the CV026 strains employed in the study, these concentrations of EB were determined to be 1 and $0.5 \mathrm{mg} / 1$, respectively $(13,24,25)$. The tubes were placed into a Rotor-Gene 3000TM thermocycler and the fluorescence monitored on a real-time basis. From the real-time data, the activity of the TF, namely the relative final fluorescence (RFF) of the last time point (minute 30) of the EB accumulation assay was calculated according to the formula:

$$
\mathrm{RFF}=\frac{\mathrm{RF}_{\text {treated }}-\mathrm{RF}_{\text {untreated }}}{\mathrm{RF}_{\text {untreated }}}
$$

Where $\mathrm{RF}_{\text {treated }}$ is the relative fluorescence at the last time point of the $\mathrm{EB}$ retention curve in the presence of an inhibitor, and $\mathrm{RF}_{\text {untreated }}$ is the relative fluorescence at the last time point of the EB retention curve of the untreated control. The greater the difference between $\mathrm{RF}_{\text {treated }}$ and $\mathrm{RF}_{\text {untreated }}$, the greater the degree of EB accumulated and, therefore, the greater the degree of inhibition of the efflux pump system of the bacterium promoted by the agent at that concentration.

The RFF was then divided by the concentration of the TF that corresponded to half its MIC. This yielded a measure of the effect of each TF at a milligram level (specific activity) and therefore afforded comparison of each TF for activity against the efflux pump systems of the CV026 and E. coli AG100 strains. The experiments were repeated three times and the specific activity values presented are the average of three independent assays. This method of analysis has been previously presented (26). Thioridazine (TZ) an efflux pump inhibitor (12), was used as as a positive control.

\section{Results}

In our previous studies, the unidentified grapevine tumor isolate Ezf 10-17 proved to be an inducer of violacein production by $C$. violaceum CV026. Thus, this pair of inducer/sensor strains was successfully used to study potential QS inhibitors (21) (Figure 2). To identify Ezf 1017 , we sequenced the V3 region of $16 \mathrm{~S}$ rDNA gene from its genome. Comparing the sequence data to those found in databases, this strain proved to be a member of the Sphingomonadaceae family.

Signal production of Ezf 10-17 was analysed by TLC overlaid with $C$. violaceum CV026. As compared to the standard AHLs, Ezf 10-17 produces a strong signal that comigrates with 3-oxo-C6 AHL. Additionally, weaker signals which seem to be identical with C6 AHL, 3-oxo-C8 AHL and C8 AHL were also observed (Figure 3). These data support our earlier observations on the suitability of Ezf 1017 in QS assays with C. violaceum CV026 (21).

In order for an agent to be correctly evaluated for effects on a QS system whose intensity of colour is dependent upon the growth of the producer of the QS signal and the growth of the responding bacterium, the concentration of the agent that is to provide meaningful interpretation, must be one that does not affect the viability of either bacterium. As summarized in Table I, various TFs have antimicrobial activities against the producer and responding bacteria. Consequently, the amounts of TFs selected for the evaluation of effects on the QS system were at or below those that had no effect on the growth of either species. Because of space limitation, the range of effects of the TFs on the QS system 


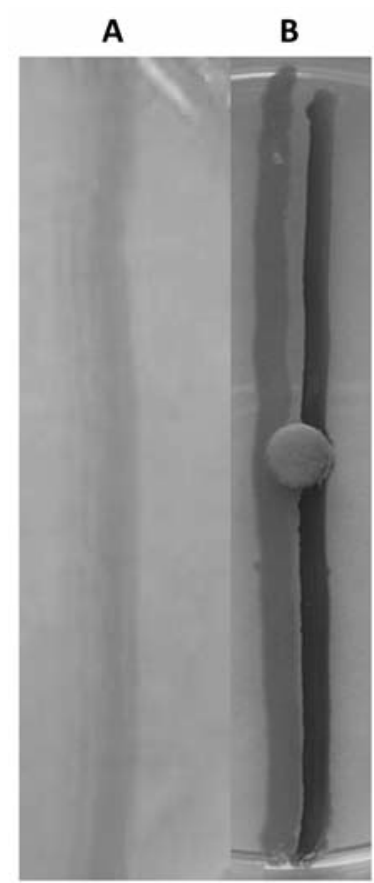

Figure 2. The quorum sensing response of CV026 to the presence of the (AHL) producer Ezf 10-17. A: CV026 responder strain alone. B: CV026 responder strain (right) with Ezf 10-17 AHL producer strain (left). The deep colour associated with the responder strain CV026 was found only when CV026 was cultured in parallel with the AHL producer Ezf 10-17.

cannot be pictorially presented. Rather, the effects are presented in Figure 4 and Table II. Briefly, TF 5 had the least inhibitory effect (deep colour associated with the responder CV026) and TF 3 had the greatest inhibitory effect on the response of the CV026. The effect of the TFs on the QS system is clearly inhibitory. Whether the effect is due to the TF inhibiting the release of the QS signal or to the inhibition of the response of the responding species cannot be distinguished from the above evaluation.

The direct effects of each TF on the QS response by CV026 was determined with the use of disks impregnated with combinations of a constant amount of the AHL and differing amounts of TF. As evident from the example provided in Figure 5, whereas the disks with $\mathrm{TF}$ alone (Figure 5A) do not produce the purple colour associated with CV026, the presence of pure AHL in the disk led to the production of the deep purple colour associated with CV026 (Figure 5B). The presence of the TF that inhibited the production of colour in the QS assay described, when in combination with the AHL, inhibits the production of the purple colour by the responding CV026 (Figure 5C). These results clearly show that the TF has a powerful inhibitory effect on the QS responding strain. However, the question of whether the same TF can inhibit the secretion of the QS signal by the producer species remains

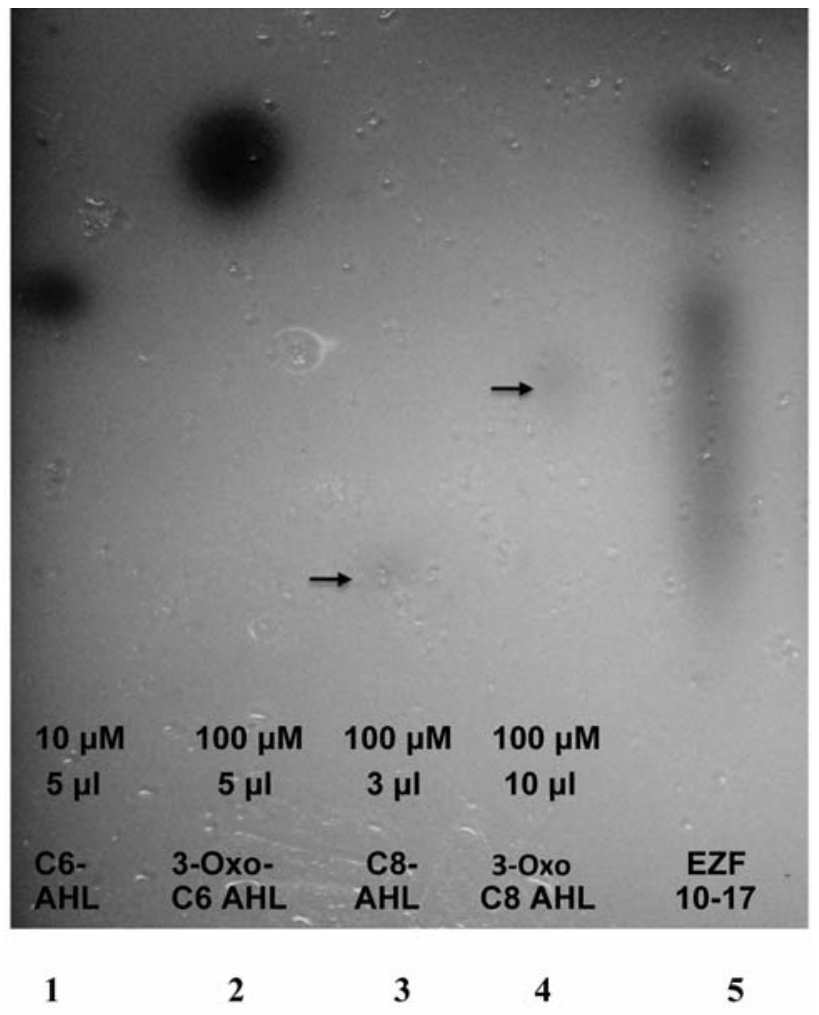

Figure 3. Detection of N-acyl-homoserine lactones (AHL) from Ezf 10-17. Pure, commercial AHLs (lanes 1-4) and purified AHL produced by Ezf 1017 (lane 5) isolated by thin layer chromatography. The plate overlaid with the responder CV026. The application of varying concentrations of pure commerical AHLs provide standards of the degree of response (intensity of colour). EZF 10-17 AHL extracts were prepared with acidified ethyl acetate of re-suspended 4-day old cultures of EzF 10-17 grown on potato dextrose agar.

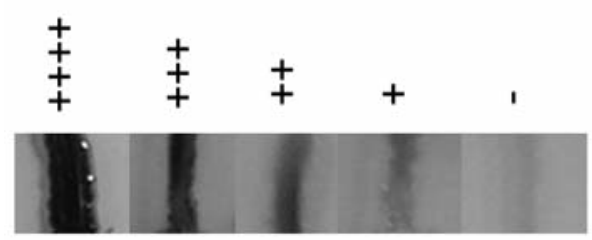

Figure 4. The length and intensity of the purple colouration induced by $10 \mathrm{ng} \mathrm{AHL/disc} \mathrm{on} \mathrm{Chromobacterium} \mathrm{violaceum} \mathrm{026,} \mathrm{after} \mathrm{24-hour}$ incubation in the presence of TFs applied at $20 \mu \mathrm{g} /$ disc. The effective inhibitors reduce the length and intensity of the purple colouration. The scale indicates an increasing intensity of colouration. A lower colour intensity means higher inhibition of QS. -, No coloration; +, whitepurple; ++ , palepurple; +++ , purple $;++++$, darkpurple.

unanswered. The activity of each TF at half its MIC on the efflux pump system of the CV026 is exemplified by Figure 6. The data presented on those figures suggest that all of the TFs have activity against the efflux pump of CV026. However, 

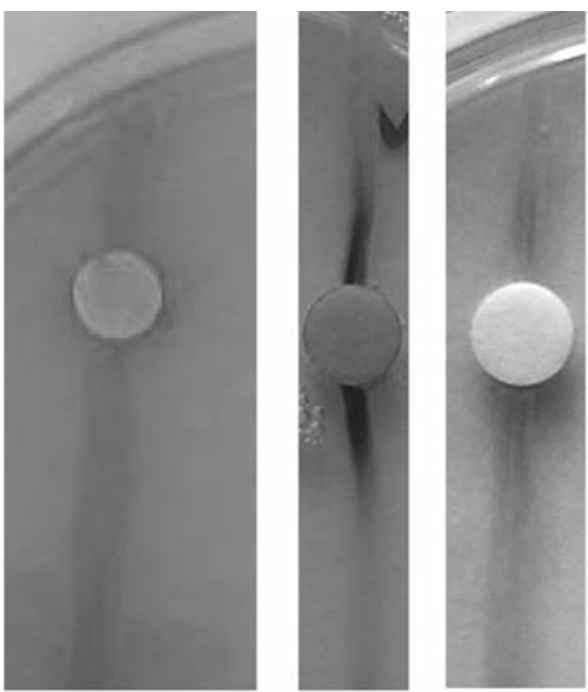

Figure 5. The effect of (TFs) on the response of CV026 (AHL). A: Control disc with TF4 $(20 \mu \mathrm{g})$ alone (no colour).B: Control disc with AHL (10 ng) alone (deep purple colouration). C: Disc with TF4 (20 $\mu \mathrm{g} /$ disc) and $\mathrm{AHL}$ (10 ng) (very light purple colouration).

Table II. Effects of (TFs) on (AHL)-mediated quorum sensing.

\begin{tabular}{lccc}
\hline TF & $\begin{array}{c}\text { Intensity of } \\
\text { colouration (mm) }\end{array}$ & $\begin{array}{c}\text { Length of } \\
\text { colouration (mm) }\end{array}$ & $\begin{array}{c}\text { Growth } \\
\text { inhibition }(\mathrm{mm})\end{array}$ \\
\hline $\mathbf{1}$ & +++ & 34 & 0 \\
$\mathbf{2}$ & + & 30 & 17 \\
$\mathbf{3}$ & + & 34 & 22 \\
$\mathbf{4}$ & +++ & 35 & 0 \\
$\mathbf{5}$ & +++ & 37 & 0 \\
$\mathbf{9}$ & + & 36 & 22 \\
AHL control & ++++ & 40 & 0 \\
\hline
\end{tabular}

Intensity scored as described in Figure 4.

because the concentrations of TFs used in the assay were half of their MICs, and the MICs of the TFs against the strain differed significantly, the activities presented in Figure 6 do not permit a comparison of the activities between TFs. However, calculation of the specific activity of each TF by the formula for RFF presented in the Materials and Methods section affords a comparison, and these data are presented in Table III. Briefly, the activity of the positive control thioridazine was 1.02. Comparison of the activity of each relative to the positive control, TFs $\mathbf{2}$ and $\mathbf{3}$ have the greatest activity against the efflux pump system of CV026; TFs 1, 4,5 and 9 have significant activity; and, TFs $7,8,10,11$ and 12 have no activity. The demonstrations that the TFs inhibit the response of an environmental strain to a QS signal and the same TFs inhibit the efflux pump of the environmental
Table III. The related final fluorescence (RFF) and specific activity (SA) of each (TF) on the efflux pump system of CV026. Samples consisted of saline plus $1 \mathrm{mg} / \mathrm{l}$ of ethidium bromide, $0.4 \%$ glucose, and without and with half (MIC) of positive control and TFs. Assessment of fluorescence took place at $37^{\circ} \mathrm{C}$ for 30 minutes. Data in bold identifies TFs that express very high inhibitory activity against the efflux pump system of CV026.

\begin{tabular}{lll}
\hline $\mathrm{TF}$ & RFF & SA \\
\hline $\mathbf{1}(25 \mathrm{mg} / \mathrm{l})$ & 4.20 & $\mathbf{1 . 6 8}$ \\
$\mathbf{2}(6,25 \mathrm{mg} / \mathrm{l})$ & 2.99 & $\mathbf{4 . 7 8}$ \\
$\mathbf{3}(6,25 \mathrm{mg} / \mathrm{l})$ & 2.21 & $\mathbf{3 . 5 3}$ \\
$\mathbf{4}(25 \mathrm{mg} / \mathrm{l})$ & 4.42 & $\mathbf{1 . 7 7}$ \\
$\mathbf{5}(25 \mathrm{mg} / \mathrm{l})$ & 5.10 & $\mathbf{2 . 0 4}$ \\
$\mathbf{6}(100 \mathrm{mg} / \mathrm{l})$ & 4.31 & $\mathbf{0 . 4 3}$ \\
$\mathbf{7}(100 \mathrm{mg} / \mathrm{l})$ & 0.92 & 0.09 \\
$\mathbf{8}(100 \mathrm{mg} / \mathrm{l})$ & 1.24 & 0.01 \\
$\mathbf{9}(25 \mathrm{mg} / \mathrm{l})$ & 3.97 & $\mathbf{1 . 5 9}$ \\
$\mathbf{1 0}(100 \mathrm{mg} / \mathrm{l})$ & 0.44 & 0.04 \\
$\mathbf{1 1}(100 \mathrm{mg} / \mathrm{l})$ & 0.73 & 0.07 \\
$\mathbf{1 2}(100 \mathrm{mg} / \mathrm{l})$ & 1.18 & 0.12 \\
\hline
\end{tabular}

$\mathrm{SA}=\mathrm{RFF} /(0.5 \mathrm{MIC})$.

Table IV. The effects of (TFs) on the efflux pump system of Escherichia coli $A G 100$.

\begin{tabular}{lrl}
\hline Sample & RFF & SA \\
\hline AG100 control & 0.5397 & 0.000 \\
+ TZ positive control. $30 \mathrm{mg} / 1$ & 11.8703 & 0.6998 \\
+ TF $\mathbf{1} .5 \mathrm{mg} / 1$ & 5.0638 & $\mathbf{1 . 1 1 7 6}$ \\
+ TF $23.75 \mathrm{mg} / 1$ & 12.9179 & $\mathbf{6 . 1 1 6 0}$ \\
+ TF $33.75 \mathrm{mg} / 1$ & 10.4916 & $\mathbf{4 . 9 1 7 2}$ \\
+ TF $430 \mathrm{mg} / 1$ & 31.1324 & $\mathbf{1 . 8 8 9 4}$ \\
+ TF $\mathbf{5} 7.5 \mathrm{mg} / 1$ & 7.8839 & $\mathbf{1 . 8 1 4 3}$ \\
+ TF $630 \mathrm{mg} / 1$ & 5.1950 & 0.2875 \\
+ TF $7240 \mathrm{mg} / 1$ & 7.2390 & 0.0517 \\
+ TF $860 \mathrm{mg} / 1$ & 6.9595 & 0.1982 \\
+ TF $97.5 \mathrm{mg} / 1$ & 6.4451 & $\mathbf{1 . 4 5 8 9}$ \\
+ TF $\mathbf{1 0} 240 \mathrm{mg} / 1$ & 19.3553 & 0.1452 \\
+ TF $\mathbf{1 1} 120 \mathrm{mg} / 1$ & 6.6206 & 0.0938 \\
+ TF $\mathbf{1 2} 60 \mathrm{mg} / 1$ & 7.0865 & 0.2021 \\
\hline
\end{tabular}

RFF: Relative final fluorescence; SA: specific activity $=\mathrm{RFF} /(0.5 \mathrm{MIC})$. Samples consisted of saline plus $1 \mathrm{mg} / 1$ of ethidium bromide, $0.4 \%$ glucose, and without and with half (MIC) of positive control and TFs. Assessment of fluorescence took place at $37^{\circ} \mathrm{C}$ for $30 \mathrm{~min}$. Data in bold identifies TFs that express very high inhibitory activity against the efflux pump system of E. coli.

responding strain, by themselves, do not support clinical interest in the TFs for possible use in the therapy of a bacterial infection. Therefore, in order to establish the needed support for the claim that indeed, the TFs have clinical value, the TFs were examined for activity against the efflux pump system of E. coli, a pathogenic bacterium. Since the number of graphs needed to depict each effect is large, an example of the data 


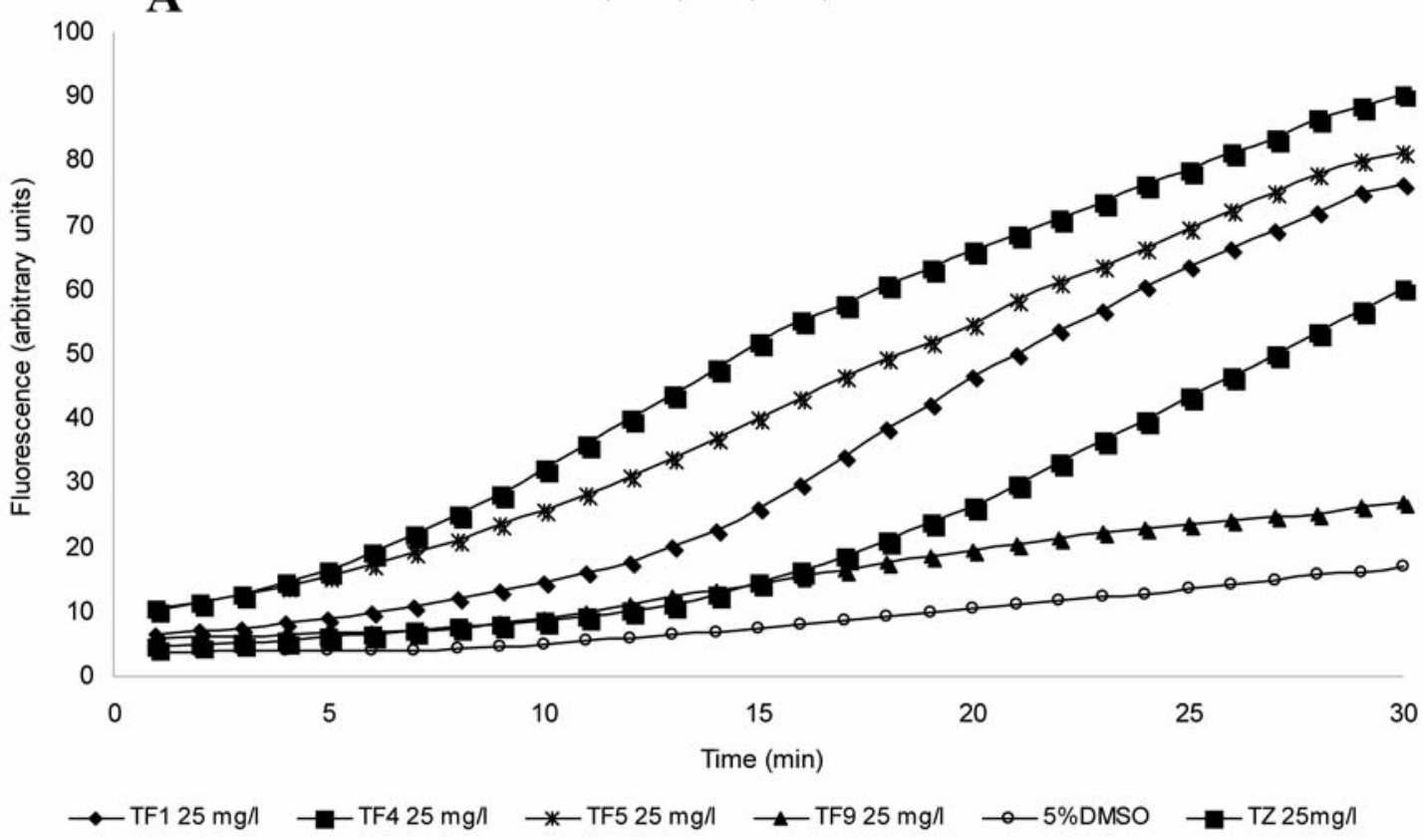

B TF6, 7, 8, 10, 11, 12, TZ

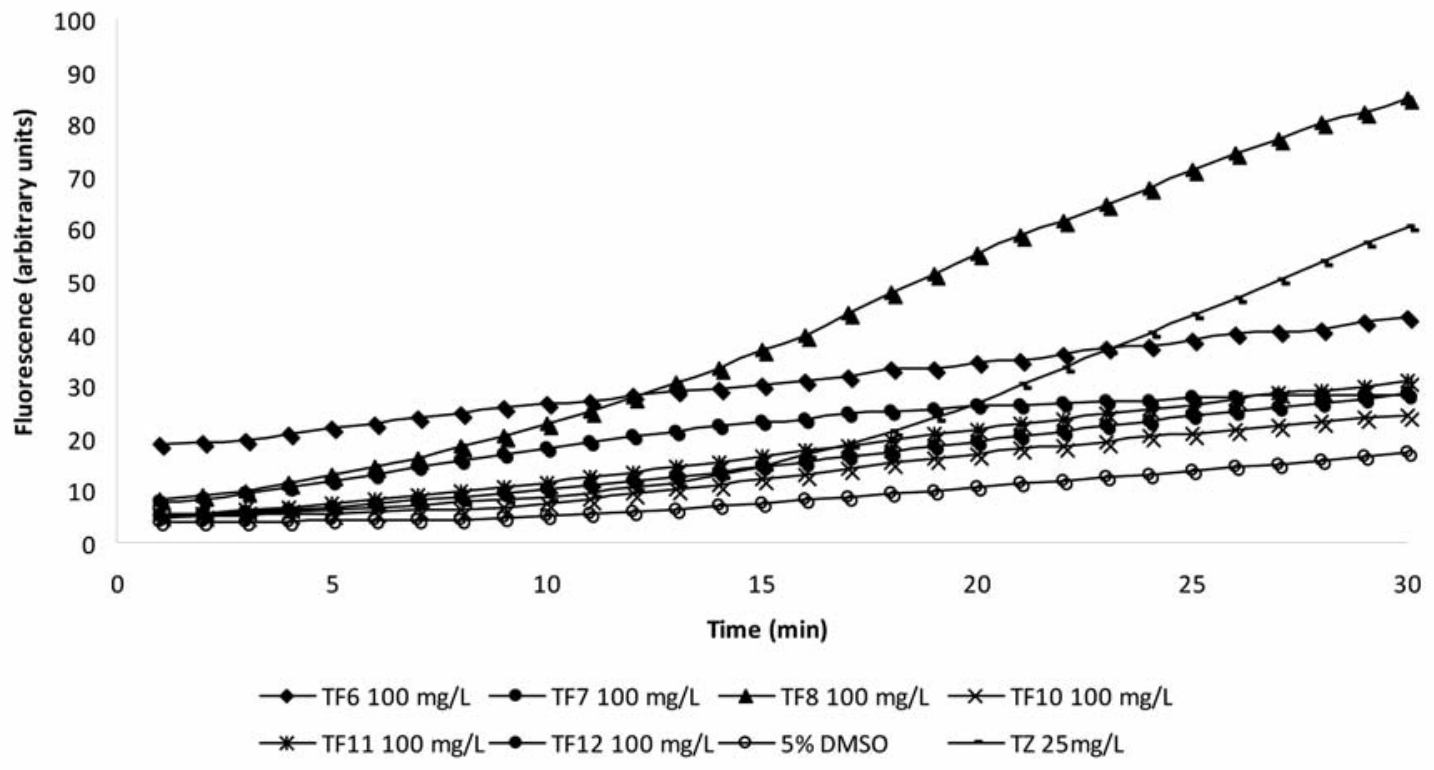

Figure 6. The effect of half the minimum inhibitory concentration of (TFS) $1,4,5,9(A)$, and $6,7,8,10,11,12$ (B) as compared to the positive control thioridazine (TZ).

obtained is presented in Figure 7 for TF 4. As evident from the figure, the presence of TF 4 promotes an increase of fluorescence due to the accumulation of $\mathrm{EB}$ whereas in the absence of the compound, no significant increase of fluorescence takes place (the curve is rather flat). The effects of the TFs on the activity of the efflux pump is summarised in Table IV. This Table provides the concentration of the positive control thioridazine and each of the TFs that corresponds to half their MIC. As noted in Table IV, TFs 2 and 3 have the highest activity against the efflux pump system of 


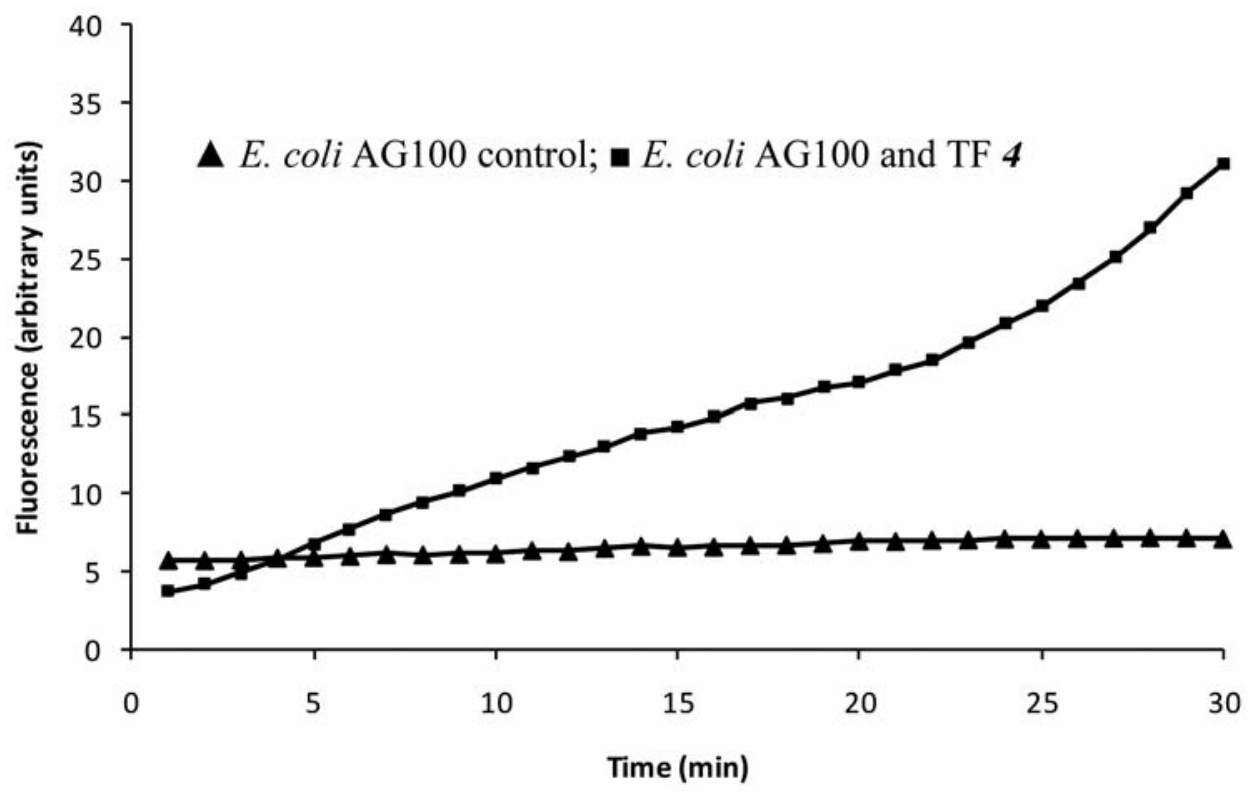

Figure 7. The effect of TF 4 on the activity of the efflux pump system of Escherichia. coli AG100. The concentration of the TF 4 that correspond to half minimum inhibitory concentration was $30 \mathrm{mg} / \mathrm{l}$. Note that the control does not accumulate ethidium bromide during the 30 minutes of the assay.

E. coli. TFs $1,4,5$ and 9 are also very active since their inhibitory activity exceeds that of thioridazine, the efflux pump inhibitor that serves as positive control.

\section{Discussion}

The results presented in this study show that some TFs have inhibitory activities against the response of CV026 to a QS signal such as AHL and the efflux pump systems of the CV026 and $E$. coli strains. Comparison of the efflux pump inhibitory activities of the TFs towards both strains suggests that the inhibition is practically identical in both cases. This suggests that the TFs have clinical value. Comparison of the individual inhibition induced by each TF on the QS response by CV026 to AHLs indicates that TF 3 exerts the greatest inhibition on the QS response. By comparison of the MIC of each effective TF, it is clear that the most effective inhibitors of the efflux pump system of $E$. coli also have the most potent antibacterial activity. TFs such as TF $7, \mathbf{1 0}$ and $\mathbf{1 1}$ are devoid of any significant antibacterial activity (MIC for TF 7 and 10 is $480 \mathrm{mg} / \mathrm{l}$, and for TF 11, it is $240 \mathrm{mg} / \mathrm{l}$ ) and have little activity against the efflux pump of E. coli. The demonstration of a QS response by the method used in this study requires the growth of the responding organism. If an agent inhibits growth, it pre-empts any response since there are no bacteria present to respond. The application of $20 \mu \mathrm{g}$ of each TF to discs promoted strong antibacterial effects by TFs with very low MICs. Applying amounts of a TF that have significant antibacterial properties to a disc below the inhibitory concentration exceeds the sensitivity of the system, since the distance between evident growth and the absence of a response (no colour) is masked by the deep purple colour associated with the growing population that is less than a millimetre from the disc. This is why TFs with very high MICs were able to produce evidence of an inhibition of the QS response by CV026, whereas for TFs with low MICs, with the exception of TF 3 (MIC $7.5 \mathrm{mg} / \mathrm{l}$ ), the antibacterial effect of the TF pre-empted growth. QS is essential for various pathogens. In nature there are many types of organisms which can quench QS signals of other species. For example, Bacillus species produce lactonase enzyme to degrade the AHL signals of Gramnegative species. Eukaryotic cells also deploy QS inhibitors to prevent bacterial infection. QS has great importance in the organisation of biofilms (6), the production of virulence factors (8), and also in the spread of antibiotic resistance. The antibiotic resistance of bacteria in biofilms is several hundred or even thousand-fold higher than the one of free living bacteria. Without the ability to make biofilms or virulence factors production, pathogens lose the ability to cause infections. Therefore, if we reduce or completely block bacterial QS, we can reduce these QS-dependent/related activities as well. Our previous study demonstrated that phenothiazines were able to inhibit the QS system that involved Ezf 10-17, the producer of the signal and CV026, the responder to the signal (27). The phenothiazine thioridazine, an inhibitor of efflux pumps of Gram-negative bacteria $(11,12,24,25)$ also inhibits the response of CV026 to pure AHL (data not shown). Because phenothiazines and TFs that inhibit the efflux pumps of the CV026 and E. coli, as shown in the current study, also inhibit 
access to energy supplied by the PMF $(4,5)$, we believe that the response to a QS signal depends upon a functional efflux pump system which extrudes the noxious QS signal before it reaches its intended target. Moreover, because all secretory activity of a bacterium such as the secretion of a QS signal, is controlled (2830 ), and the main efflux pump systems of Gram-negative bacteria are the secretory paths of internally produced noxious agents (31-34), the inhibition of the efflux pump system of a QS signal producer will result in obviating the secretion of the QS signal. Therefore, it is our contention that inhibitors of an efflux pump, such as phenothiazines and now also TFs, will inhibit the secretion of the QS signal and the response to the QS signal. The results of the current study clearly show that various TFs have the ability to inhibit the response of $C$. violaceum 026 to the QS signal AHL and to inhibit the efflux pump of the QSresponding CV026 as well as the one of E. coli. This ability is a direct one since none of the TFs formed a complex with AHL (spectrophotometric data not shown). Since some TFs inhibit the QS response, inhibit an efflux pump system and also have significant antibacterial activity, TFs have a promising future for therapy of problematic infections that rely on an effluxmediated multidrug-resistant phenotypes and which, due to QS, make their therapy problematic.

\section{Acknowledgements}

The Authors are grateful for the support from the Szeged Foundation of Cancer Research and a Grant-in-Aid from the Ministry of Education, Science and Culture of Japan (Kawase, no. 20590114). L. Amaral was supported by BCC grant SFRH/BCC/51099/2010 provided by the Fundação para a Ciência e a Tecnologia (FCT) of Portugal. Mior Ahmad Subki is currently enrolled in the Biotechnology Program at Rochester Institute of Technology (RIT, NY, USA) and was supported by a Undergraduate Research Fellowship from the American Society for Microbiology and the College of Science at RIT. M. A. Savka wishes to thank the School of Biological and Medical Sciences, College of Science, at RIT for the support of this work through Faculty Evaluation and Development (FEAD) 2010 awards. E. Szegedi was supported by Hungarian Scientific Research Fund (OTKA) Grant no. K-83121. The Authors are grateful for the skilful technical assistance of Aniko Váradi Vigyikán.

\section{References}

1 Kawase M, Motohashi N, Sakagami H, Kanamoto T, Nakashima $\mathrm{H}$, Ferenczy L, Wolfard K, Miskolci Cs and Molnár J: Antimicrobial activity of trifluoromethyl ketones and their synergism with promethazine. Int $\mathrm{J}$ Antimicrobial Agents 18: 161-165, 2001.

2 Wolfart K, Molnar A, Kawase M, Motohashi N and Molnar J: Effect of trifluoromethyl ketones on the motility of Proteus vulgaris. Biol Pharm Bull 27: 1462-1464, 2004.

3 Spengler G, Molnár A, Klausz G, Mándy I, Kawase M, Motohashi $\mathrm{N}$ and Molnar $\mathrm{J}$ : The antimotility action of trifluoromethyl ketone on some Gram-negative bacteria. Acta Microbiol Immunol Hung 51: 351-358, 2004.
4 Spengler G, Molnár A, Klausz G, Mándy I, Kawase M, Motohashi $\mathrm{N}$ and Molnar J: Inhibitory action of a new proton pump inhibitor, trifluoroketone derivative against the motility of clarithromycin-susceptible and resistant Helicobacter pylori. Int J Antimicrobial Agents 23: 631-633, 2004.

5 Molnár A, Wolfart K, Kawase M, Motohashi N and Molnar J: Effect of trifluoromethyl ketone on the motility of proton pump deficient mutant of E. coli strain and its wild-type. In Vivo 18: 505-508, 2004.

6 Dickshat JS: Quorum sensing and bacterial biofilms. Nat Pro Rep 27: 343-369, 2010.

7 Amara N. Mashiach R, Amar D, Krief P, Spieser S, Bottomley M, Aharoni A and Meijler M: Covalent inhibition of bacterial quorum sensing. J Am Chem Soc 131: 10610-10619, 2009.

8 Chan WC, Coyle BJ and Williams P: Virulence regulation and quorum sensing in Staphylococcal infections: Competitive AgrC antagonists as quorum-sensing inhibitors. J Med Chem 47: 46334641, 2004.

9 Pumbwe L, Skilbeck CA and Wexler HM: Presence of quorumsensing systems associated with multidrug resistance and biofilm formation in Bacteroides fragilis. Microb Ecol 56: 412-9, 2008.

10 Kvist M, Hancock V, Klemm P: Inactivation of efflux pumps abolishes bacterial biofilm formation. Appl Environ Microbiol 74: 7376-7382, 2008.

11 Amaral L, Fanning S and Pagès JM: Efflux pumps of gramnegative bacteria: genetic responses to stress and the modulation of their activity by $\mathrm{pH}$, inhibitors, and phenothiazines. Adv Enzymol Relat Areas Mol Biol 77: 61-108, 2011.

12 Amaral L, Cerca P, Spengler G, Machado L, Martins A, Couto I, Viveiros M, Fanning S and Pages JM: Ethidium bromide efflux by Salmonella: modulation by metabolic energy, $\mathrm{pH}$, ions and phenothiazines. Int J Antimicrob Agents 38: 140-145, 2011.

13 Martins A, Iversen C, Rodrigues L, Spengler G, Ramos J, Kern WV, Couto I, Viveiros M, Fanning S, Pages JM and Amaral L: An AcrAB-mediated multidrug-resistant phenotype is maintained following restoration of wild-type activities by efflux pump genes and their regulators. Int J Antimicrob Agents 34: 602-604, 2009.

14 Kawase M, Teshima M, Saito S and Tani S: Trifluoroacetylation of methylpyridines and other methylazines: A convenient access to trifluoroacetonylazines. Heterocycles 48: 2103-2109, 1998.

15 Lipshutz BH, Hungate RW: Metalation studies of trisubstituted oxazoles. J Org Chem 46: 1410-1413, 1981.

16 Babichev FS and Volovenko YM: Acylation of 2-methylbenzazoles by carboxylic acid esters. Ukrainskii Khimicheskii Zhurnal 43: 163-165, 1977 (in language of original).

17 Ballantine JA, Beer RJS, Crutchley DJ, Dodd GM and Palmer DR: The synthesis of violacein and related compounds. Proc Chem Soc pp. 232-233, 1968.

18 McClean KH, Winson MK, Fish L, Taylor A, Chhabra SR, Camara M, Daykin M, Lamb JH, Swift S, Bycroft BW, Stewart GSAB and Williams P: Quorum sensing and Chromobacterium violaceum: exploitation of violacein production and inhibition for the detection of $N$-acyl homoserine lactones. Microbiology 143: 3703-3711, 1997.

19 Lithgow JK, Danino VE, Jones J and Downie JA: Analysis of $N$ acyl homoserine-lactone quorum-sensing molecules made by different strains and biovars of Rhizobium leguminosarum containing different symbiotic plasmids. Plant and Soil 232: 312,2001 
20 Molina L, Constantinescu F, Michel L, Reimmann C, Duffy B and Defago G: Degradation of pathogen quorum-sensing molecules by soil bacteria: a preventive and curative biological control mechanism. FEMS Microbiol Ecol 45: 71-81, 2003.

21 McClean RJC, Pierson LS, Fuqua CA: Simple screening protocol for the identification of quorum signal antagonists. $\mathrm{J}$ Microbiol Methods 58: 351-360, 2004

22 Szabó MA, Varga GZ, Hohmann J, Schelz Zs, Szegedi E, Amaral L and Molnar J: Inhibition of quorum-sensing signals by essential oils. Phytother Res 24: 782-786, 2010.

23 Clinical and Laboratory Standards Institute. Performance Standards for Antimicrobial Susceptibility Testing; Seventeenth Informational Supplement. CLSI document 27(1): M100-S17, 2007.

24 Viveiros M, Martins M, Couto I, Rodrigues L, Spengler G, Martins A, Kristiansen JE, Molnar J and Amaral L: New Methods for the Identification of Efflux-mediated MDR Bacteria; Genetic Assessment of Regulators and Efflux Pump Constituents, Characterization of Efflux Systems and Screening for Inhibitors of Efflux Pumps: Current Drug Targets 9: 760-778, 2008.

25 Viveiros M, Rodrigues L, Martins M, Couto I, Spengler G, Martins A and Amaral L: Evaluation of efflux activity of bacteria by a semi-automated fluorometric system. Methods Mol Biol 642: 159-172, 2010.

26 Takács D, Cerca P, Martins A, Riedl Zs, Hajós Gy, Molnár J, Viveiros M, Couto I and Amaral L: Evaluation of forty new phenothiazine derivatives for activity against intrinsic efflux pump systems of reference Escherichia coli, Salmonella Enteritidis, Enterococcus faecalis and Staphylococcus aureus strains. In Vivo 25: 719-724, 2011.

27 Varga GZ, Szabó MA, Hohmann J et al: Quorum Sensing Inhibition by Phenothiazines and Related Compounds Lett Drug Design Discovery 8: 133-137, 2011.

28 Singh G, Wu B, Baek MS, Camargo A, Nquyen A, Slusher NA, Srinivasan R, Wiener-Kronish JP and Lynch SV: Secretion of Pseudomonas aeruginosa type III cytotoxins is dependent on Pseudomonas quinolone signal concentration. Microb Pathog 49: 196-203, 2010.
29 He YW, Wu J, Cha JS and Zhang LH: Rice bacterial blight pathogen Xanthomonas oryzae pv. oryzae produces multiple DSF-family signals in regulation of virulence factor production. BMC Microbiol 10: 187, 2010.

30 Shen DK, Filopon D, Chaker H, Boullanger S, Derouazi M, Polack B and Toussaint B: High-cell-density regulation of the Pseudomonas aeruginosa type III secretion system: implications for tryptophan catabolites. Microbiology 154(Pt8): 2195-208, 2008.

31 Drew D, Klepsch MM, Newstead S, Flaig R, De Gier JW, Iwata $\mathrm{S}$ and Beis K: The structure of the efflux pump AcrB in complex with bile acid. Mol Membr Biol 25: 677-82, 2008.

32 Nikaido E, Yamaguchi A and Nishino K: AcrAB multidrug efflux pump regulation in Salmonella enterica serovar Typhimurium by RamA in response to environmental signals. J Biol Chem 283: 24245-53, 2008.

33 Rosenberg EY, Bertenthal D, Nilles ML, Bertrand KP and Nikaido H: Bile salts and fatty acids induce the expression of Escherichia coli AcrAB multidrug efflux pump through their interaction with Rob regulatory protein. Mol Microbiol 48: 1609-19, 2003.

34 Thanassi DG, Cheng LW and Nikaido H: Active efflux of bile salts by Escherichia coli. J Bacteriol 179: 2512-2518, 1997.
Received November 15, 2011

Revised December 22, 2011

Accepted December 23, 2011 


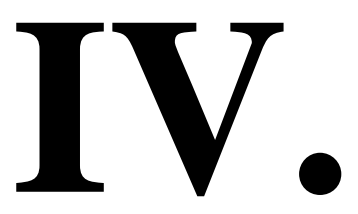




\title{
INTERFERENCE IN QUORUM SENSING SIGNAL TRANSMISSION AMONGST MICROBIAL SPECIES
}

\author{
ZOLTÁn G. VARGA ${ }^{1}$, MiRA ÁGNES SZABÓ ${ }^{1}$, MONIKA KERÉNYI ${ }^{2}$ \\ and JOSEPH MOLNÁR ${ }^{1 *}$ \\ ${ }^{1}$ Institute of Medical Microbiology and Immunobiology, University of Szeged, Hungary \\ ${ }^{2}$ Department of Medical Microbiology and Immunology, University of Pécs, Hungary
}

(Received: 26 June 2012; accepted: 27 August 2012)

\begin{abstract}
Antibiotics are usually studied on pure cultures of a single bacterial strain, whereas multi-species communities that inhabit human niches and the biosphere are generally ignored. The modification of quorum sensing (QS) is investigated in a system involving a co-existing signal producer and sensor bacterial cells. A pure culture of merely one bacterial species is quite rare in any niche. The interactions of different bacterial species may therefore be of special importance in pathogenicity, antibiotic resistance and signal transmission.

In the present study the authors investigated the QS in model experiments involving several Gram-positive and Gram-negative bacterial species isolated from human infections or laboratory strains. The effects of various compounds on QS were studied in mixed bacterial populations during the incubation period of $24-48 \mathrm{~h}$. As the simplest example of co-existing cell populations, the $\mathrm{N}$-acyl homoserine lactone producing Ezf 10-17 was applied with Chromobacterium violaceum 026 as sensor.

The signal of QS transmission between the co-existing QS system and pathogenic bacteria isolated from various patients was found to be modified by certain bacterial cells. The bacterial-bacterial interactions in a mixed flora can change the classical signal transmission in the microbial community and should therefore be taken into consideration in rational chemotherapy.
\end{abstract}

Keywords: Quorum sensing, Escherichia coli, Chromobacterium violaceum CV026, coexistence, Quorum quenching

\footnotetext{
* Corresponding author; E-mail: molnar.jozsef@med.u-szeged.hu
} 


\section{Introduction}

The quorum sensing (QS) signal systems regulate a wide spectrum of cell functions in the microbial or bacterial flora. In general, microbes contain numerous genes which are activated only when the bacterial population exceeds a threshold concentration. This population size-dependent gene regulation is known as QS. Models have been proposed for the communication of two different bacterium population, where the cells of one bacterial species produce mediator molecules, e.g. homoserine lactones, which induce pigment production in the sensor Chromobacterium violaceum, resulting in the signal transmission responsible for violacein production, antibiotic resistance and biofilm formation in the latter population.

This signal transmission can be inhibited by various compounds, with the consequence of beneficial effects. In view of this opportunity to modify the QS, it is of interest to learn what happens after the modification of QS signal transmission in a mixed bacterium population of three or more species living and growing together, as in the habitat of the surface waters, in the human mouth or gut, etc., and whether beneficial effects can be attained in signal transmission.

Various natural and synthetic compounds have been shown to exert QS inhibition in vitro [1]. The QS inhibitory effects of phenothiazines and trifluoromethyl ketones have been studied in a number of cultures containing only the sensor and producer strains [1-3]. However, there are differences in the antiplasmid effect of promethazine in mixed bacterial cultures [4]. Under natural conditions, bacteria in the environment and in the human body form multi-species communities, such as the densely populated normal and pathogenic flora of the gastrointestinal tract, skin or oral cavity [5-9]. The functions of the normal flora include maintenance of the integrity of metabolic processes, regulation of the rate of growth of pathogens and ensurance of the persistence of some type of "immunity" at the biological niche through competition.

Disturbance of the flora by antibiotics, xenobiotics or superinfections leads to functional changes mediated by QS mechanisms in the microbial communities. Those can come about through changes in virulence, antibiotic resistance, biofilm formation, etc. [10-16]. The normal QS can be modified by xenobiotics and the presence of other micro-organisms. Direct evidence has been found that $\mathrm{N}$-acyl homoserine lactones (AHLs) are decomposed by the lactonase produced by some members of the Gram-positive bacterial family Bacillaceae [17].

The objective of our present experiments was to study the stability of QS in

mixed bacterial cultures, through measurement of the QS signal transmission in 
the presence of various Gram-positive cocci, Gram-positive bacilli and Gramnegative pathogenic and non-pathogenic bacterial species. The possible modification of QS has also been determined in the presence of phenothiazine compounds in mixed bacterial cultures.

\section{Materials and Methods}

Microbial strains

The Chromobacterium violaceum CV026 sensor strain, which detects AHLs with a short acyl side-chain via development of the purple pigment violacein [18]. Ezf 10-17 (isolated from "ezerfürtü", a traditional Hungarian grape variety), which belongs in the Sphingomonadaceae family and Enterobacter cloaceae 31298 (a clinical isolate from a wound) are AHL-producing strains.

Microbes tested for QS modification or inhibition: the Candida albicans, C. tropicalis, C. krusei, Achromobacter xylosoxidans 40502, Acinetobacter baumannii 32703, A. baumannii 32905, A. baumannii 42701, Bacillus cereus, $B$. subtilis, B. clausii, B. megaterium PV 361, B. megaterium MS 941, B. megaterium 216, Staphylococcus epidermidis, S. aureus and Escherichia coli clinical isolates were applied from extraintestinal infections numbered 5536, 10902, 10904, $11925,14525,14584,18596,19579,19672,24310,24409,24442,33444,36446$ and 40312 .

Media

Blood agar complemented with sheep blood; and a modified LB medium (LB*) containing yeast extract $5 \mathrm{~g} / \mathrm{l}$, Tryptone $10 \mathrm{~g} / \mathrm{l}, \mathrm{NaCl} 10 \mathrm{~g} / 1, \mathrm{~K}_{2} \mathrm{HPO}_{4} 1 \mathrm{~g} / \mathrm{l}$, $\mathrm{MgSO}_{4} \times 7 \mathrm{H}_{2} \mathrm{O} 0.3 \mathrm{~g} / \mathrm{l}$ and FeNaEDTA $36 \mathrm{mg} / \mathrm{l}$, supplemented with agar (Difco) $20 \mathrm{~g} / \mathrm{l})(\mathrm{pH} 7.2)$.

QS modification experiments with E. coli strains

Suspensions of each E. coli strain were separately mixed with molten LB* agar medium. One hour later parallel lines of the pair of CV026 sensor and

Acta Microbiologica et Immunologica Hungarica 59, 2012 
Ezf 10-17, and E. cloaceae 31298 AHL-producing strains were inoculated and incubation was performed at room temperature $\left(20^{\circ} \mathrm{C}\right)$ for $24-48 \mathrm{~h}$.

\section{QS inhibition of bacterial strains}

Each investigated strain was inoculated at right angles through the parallel lines of the pair of CV026 sensor and EZF 10-17 AHL-producing strains, and then incubated at room temperature for further $24-48 \mathrm{~h}$. LB* media were used, for Candida, Acinetobacter, Achromobacter, Bacillus, E. coli and Staphylococcus species, etc. For Streptococcus species, blood agar was used, and the plates were pre-incubated for $5 \mathrm{~h}$ at $37^{\circ} \mathrm{C}$ and further incubation being continued at room temperature. QS inhibition was revealed as a decreased level of violacein production by CV026.

\section{Results}

Our results reflect ex vivo interactions, and exemplify various bacterial interactions on QS.

We investigated 31 bacteria and 3 yeast strains for their ability to inhibit or modify QS (Tables I and II), of which two bacterial genera, Escherichia and Bacil$l u s$, proved to be effective inhibitors. Of the 6 investigated bacillus strains, $B$. cereus was the best inhibitor, with a clear QS inhibitory effect (Fig. 1), while B. subtilis and B. clausii inhibited QS moderately, and the three B. megaterium strains (PV361, MS941 and 216) did not exhibit any QS inhibitory activity (Table I).

Surprisingly, 14 of the 15 investigated Escherichia clinical isolates were effective inhibitors and only one had no inhibitory effect. We investigated the QS inhibitory activity between E. cloaceae 31298 and CV026 and also between Ezf 10-17 and CV026: 10 strains exerted an antibacterial effect on E. cloaceae, and 4

of them inhibited the growth of CV026 too (Table II). The antibacterial effects of the E. coli isolates on E. cloaceae were more pronounced than those on Ezf 10-17. This probably originated from the long co-evolution in the same niche. The 2 strains, with antibacterial activity on Ezf 10-17 also had antibacterial effects on E. cloaceae 31298 and CV026. There were 5 strains which had no growth inhibitor activity against either the sensor or the producer strains.

Acta Microbiologica et Immunologica Hungarica 59, 2012 
Table I

Effects of various bacterial and Candida species on QS signal transmission

\begin{tabular}{|c|c|c|}
\hline Strain & Medium & QS inhibition \\
\hline Candida albicans 40502 & $\mathrm{LB}^{*}$ & - \\
\hline Candida tropicalis 47402 & LB* & - \\
\hline Candida krusei 47813 & LB* & - \\
\hline Acinetobacter baumannii 32703 & LB* & - \\
\hline Acinetobacter baumannii 32905 & LB* & - \\
\hline Acinetobacter baumannii 42701 & LB* & - \\
\hline Achromobacter xylosoxidans 40502 & LB* & - \\
\hline Staphylococcus aureus & LB* & - \\
\hline Staphylococcus epidermidis & LB* & - \\
\hline Bacillus subtilis & LB* & moderate \\
\hline Bacillus cereus & $\mathrm{LB}^{*}$ & + \\
\hline Bacillus clausii & LB* & moderate \\
\hline Bacillus megaterium PV 361 & $\mathrm{LB}^{*}$ & - \\
\hline Bacillus megaterium MS 941 & LB* & - \\
\hline Bacillus megaterium 216 & LB* & - \\
\hline Streptococcus pneumoniae & blood agar & - \\
\hline Streptococcus salivarius & blood agar & - \\
\hline Streptococcus agalactiae & blood agar & - \\
\hline Streptococcus pyogenes & blood agar & - \\
\hline
\end{tabular}

All of the tested isolates except strain 19579 modified the QS (Table II). The most exciting strains were 5539, 24310, 33444 and 40312, which strongly inhibitied the established QS system, but the tested isolates did not affect the growth of the indicator and 2 producer strains (Fig. 2).

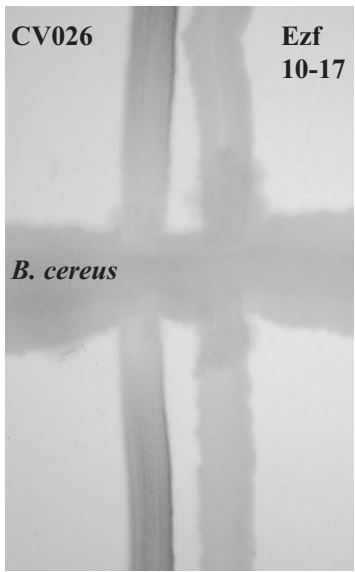

Figure 1. QS inhibitory activity of B. cereus in the system containing the CV026 sensor and Ezf 10-17 producer strain.

The inhibition of QS is revealed in the decreased level of violacein production 


\section{Table II}

Effects of various $E$. coli strains on the QS signal transmission between CV026 sensor and Ezf 10-17 and E. cloaceae 31298 AHL producer strains

\begin{tabular}{|c|c|c|c|c|c|}
\hline $\begin{array}{l}\text { E. coli } \\
\text { strain } \\
\text { number }\end{array}$ & $\begin{array}{l}\text { Growth } \\
\text { inhibition } \\
\text { of CV026 }\end{array}$ & $\begin{array}{c}\text { Growth } \\
\text { inhibition } \\
\text { of Ezf } 10-17\end{array}$ & $\begin{array}{c}\text { Growth } \\
\text { inhibition of } \\
\text { E. cloaceae } 31298\end{array}$ & $\begin{array}{c}\text { QS } \\
\text { inhibition }\end{array}$ & $\begin{array}{l}\text { Origin of } \\
\text { isolate } \\
\text { (specimen) }\end{array}$ \\
\hline 5536 & - & - & - & + & abscess \\
\hline 10902 & + & + & + & + & blood culture \\
\hline 10904 & + & + & + & + & blood culture \\
\hline 11925 & - & - & + & + (very low) & blood culture \\
\hline 14525 & - & - & + & + & abdominal wound \\
\hline 14584 & + low & - & + & + & conjunctiva \\
\hline 18596 & + low & - & + & + & wound \\
\hline 19579 & - & - & - & - & urine \\
\hline 19672 & + & - & + & + & urine \\
\hline 24310 & - & - & - & + & blood culture \\
\hline 24409 & - & - & + & + & blood culture \\
\hline 24442 & - & - & + (very low) & + & blood culture \\
\hline 33444 & - & - & - & + & blood culture \\
\hline 36446 & - & - & + & + & blood culture \\
\hline 40312 & - & - & - & + & blood culture \\
\hline
\end{tabular}

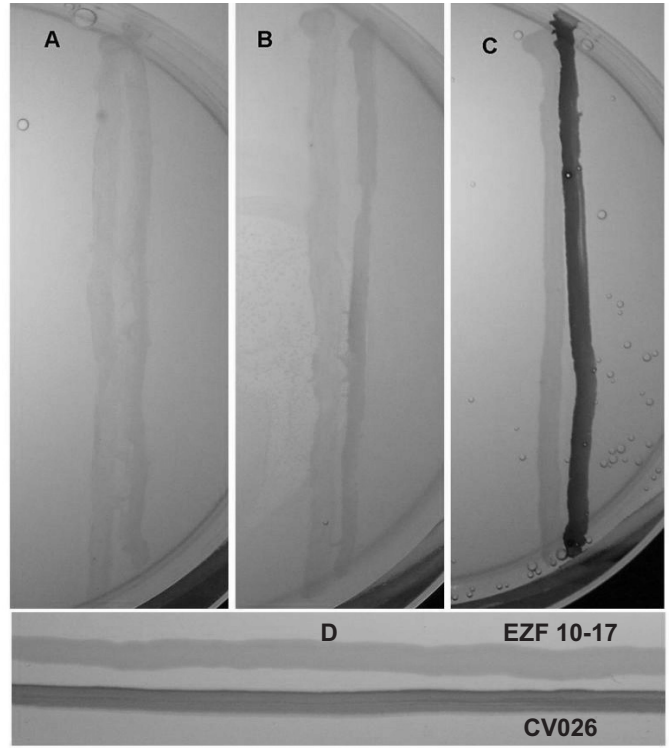

Figure 2. The interference of different $E$. coli strains with the QS signal between the CV026 sensor and the Ezf 10-17 producer strain. The sensor and producer strains are situated on the top of the medium containing different $E$. coli strains

A: Strain 5536 lacks QS between the sensor CV026 and producer Ezf 10-17 strains;

B: Strain 11925 has high QS inhibitor activity;

C: Strain 19579 has no QS inhibitor activity; D: Control 
Interestingly, phenothiazines enhanced the QS inhibitory effect of the ineffective E. coli 19579 and the 2 bacillus strains, which display moderate QS inhibitory effects without phenothiazines.

\section{Discussion}

In nature, bacteria live in a complex environment, in which they share their niche with a number of other bacterial and eukaryotic cells. Bacterial cells must select among numerous alternatives to find the most advantageous way to coexist with their neighbours and to maintain their own optimal population level. They may gain benefit from the quorum quenching of other species. The microbial world is very complex with an abundance of social interactions, and bacteria with QS systems can acquire many benefits.

Mixed bacterial infections are common in oropharyngeal, gastrointestinal and urinary tract infections. The presence of different bacterial species can result in difficulties in chemotherapy because the co-existing bacterial population can modify the interspecies communications and horizontal gene transfer [4].

Nature provides numerous examples of bacterial-bacterial and eukaryoticbacterial interactions [17, 19-26]. As an example a furanosyl borate diester, autoinducer II (AI2), a universal signal molecule that is characteristic in both Gram-negative and Gram-positive bacteria, plays a very important role in bacterial-bacterial interspecies communication. Bacteria also synthesize molecules with special effects on eukaryotic cells. For instance, Pseudomonas aeruginosa operates with a signal molecule, N-3-O-dodecanoyl homoserine lactone, which exerts various effects on mammalian cells, induces apoptosis and modulates the expression of immune mediators in murine fibroblast and human vascular epithelial cells [20].

Among the many alternatives available to silence the QS of competitive bacteria, probably the most common way is the production of lactonase, an enzyme which opens the lactone ring of AHLs, this being a characteristic feature of the majority of Bacillus species [17]. Another widely used alternative for inactivating AHLs is AHL-acylase production, which can occur in both Gram-positive and Gram-negative bacteria. These enzymes are more specific than lactonases. The AHL-acylase of Ralstonia eutropha is more effective on AHLs with a long acyl side-chain [21], whereas that of Streptomyces sp. strain M664 exerts a high AHL-degrading effect on AHLs with a short acyl side-chain [22]. This is why a 
bacterium which communicates with short-chain AHLs can quench long acyl side-chain AHLs without affecting its own communication, and vice versa.

Our results have afforded some evidence of the complexity of bacterial-bacterial interactions. Of the tested isolates, E. coli strains proved to be the best inhibitors of the AHL-dependent QS, 14 of the 15 samples exhibiting an inhibitory effect. There are a number of possibilities to explain why E. coli strains are such good QS inhibitors in our system. They may produce signals which compete with the AHL signals of CV026, or metabolize the signal molecules, or use systems like the AI2 importers. E coli possesses a special strategy to compete with the AI2 signals of other bacteria. E. coli strains have AI 2 specific importers, which are activated at a high level of the inducer molecules. The import of AI2 eliminates these signals from the extracellular environment [19]. These importers probably play a role in the AHL-dependent QS inhibitory effects too in our system. Another, perhaps the most likely way to reduce AHLs from the environment, is the AHL sensing of E. coli. This bacterium cannot produce AHLs but has special LuxR-solo receptors, SdiA, which allow it to detect foreign AHLs. This competitive binding probably reduces the number of signal molecules in the population below the threshold concentration [27, 28].

Further studies are clearly needed to clarify the interactions between the various bacterial species in a biological niche, e.g. in the range from the human gut flora to surface waters in nature.

\section{Acknowledgements}

The authors acknowledge the skillful technical assistance of Anikó Várady Vigyikán and Marianna Ábrahám, Institute of Medical Microbiology and Immunobiology, University of Szeged, Szeged, Hungary. This work was supported by ÁOK grant KA-34038/10-13, TÁMOP 422B and the Szeged Foundation of Anticancer Research.

\section{References}

1. Szabó, M. A., Varga, G. Z., Hohmann, J., Schelz, Zs., Szegedi, E., Amaral, L., Molnar, J.: Inhibition of quorum-sensing signals by essential oils. Phytother Res 24, 782-786 (2010).

2. Varga, G. Z., Szabó, M. A., Hohmann, J., Schelz, Zs., Szegedi, E., Amaral, L., Molnar, J.: Quorum sensing inhibition by phenothiazines and related compounds. Lett Drug Design Discovery 8, 133-137 (2011).

Acta Microbiologica et Immunologica Hungarica 59, 2012 
3. Varga, Z. G., Armada, A., Cerca, P., Amaral, L., Subki, M. A., Savka, M. A., Szegedi, E., Kawase, M., Motohashi, N., Molnar, J.: Inhibition of quorum sensing and efflux pump system by trifluoromethyl ketone proton pump inhibitors. In Vivo 26, 277-285 (2012).

4. Molnár, A., Amaral, L., Molnár, J.: Antiplasmid effect of promethazine in mixed bacterial cultures. Int J Antimicrob Agents 22, 217-222 (2003).

5. Rosenthal, M., Goldberg, D., Aiello, A., Larson, E., Foxman, B.: Skin microbiota: Microbial community structure and its potential association with health and disease. Infect Genet Evol 11, 839-848 (2011).

6. Zhu, B., Wang, X., Li, L.: Human gut microbiome: The second genome of human body. Protein Cell 1, 718-725 (2010)

7. Filoche, S., Wong, L., Sissons, C. H.: Oral biofilms: Emerging concepts in microbial ecology. J Dent Res 89, 8-18 (2010).

8. Hojo, K., Nagaoka, S., Ohshima, T., Maeda, N.: Bacterial interactions in dental biofilm development. J Dent Res 88, 982-990 (2009).

9. Parahitiyawa, N. B., Scully, C., Leung, W. K., Yam, W. C, Jin, L. J., Samaranayake, L. P.: Exploring the oral bacterial flora: Current status and future directions. Oral Dis 16, 136-145 (2010).

10. Reeser, R. J., Medler, R. T., Billington, S. J., Jost, B. H., Joens, L.A.: Characterization of Campylobacter jejuni biofilms under defined growth conditions. Appl Environ Microbiol 73, 1908-1913 (2007).

11. Ji, G., Beavis, R., Novick, R. P.: Cell density control of staphylococcal virulence mediated by an octapeptide pheromone. Proc Natl Acad Sci 92, 12055-12059 (1995).

12. Pumbwe, L., Skilbeck, C. A., Wexler, H. M.: Presence of quorum-sensing systems associated with multidrug resistance and biofilm formation in Bacteroides fragilis. Microb Ecol 56, 412-419 (2008).

13. Liu, X., Bimerew, M., Ma, Y., Müller, H., Ovadis, M., Eberl, L., Berg, G., Chernin, L.: Quorum-sensing signaling is required for production of the antibiotic pyrrolnitrin in a rhizospheric biocontrol strain of Serratia plymuthica. FEMS Microbiol Lett 270, 299-305 (2007).

14. Tian, Y., Wang, Q., Liu, Q., Ma, Y., Cao, X., Guan, L., Zhang, Y.: Involvement of LuxS in the regulation of motility and flagella biogenesis in Vibrio alginolyticus. Biosci Biotechnol Biochem 72, 1063-1071 (2008).

15. Dunny, G. M.: The peptide pheromone-inducible conjugation system of Enterococcus faecalis plasmid pCF10: Cell-cell signalling, gene transfer, complexity and evolution. Philos Trans R Soc Lond B Biol Sci 29, 1185-1193 (2007).

16. Tomasz, A.: Control of the competent state in Pneumococcus by a hormone-like cell product: An example for a new type of regulatory mechanism in bacteria, Nature 9, 155-159 (1965).

17. Dong, Y. H., Gusti, A. R., Zhang, Q., Xu, J. L., Zhang, L. H.: Identification of quorum-quenching $\mathrm{N}$-acyl homoserine lactonases from Bacillus species. Appl Environ Microbiol 68, 1754-1759 (2002).

18. McClean, K. H, Winson, M. K., Fish, L., Taylor, A., Chhabra, S. R., Camara, M., Daykin, M., Lamb, J. H., Swift, S., Bycroft, B. W., Stewart, G. S. A. B., Williams, P.: Quorum sensing and Chromobacterium violaceum: exploitation of violacein production and inhibition for the detection of N-acyl homoserine lactones. Microbiology 143, 3703-3711 (1997).

19. Xavier, K. B., Bassler, B. L.: Interference with AI-2-mediated bacterial cell-cell communication. Nature 437, 750-753 (2005). 
20. Shiner, E. K., Terentyev, D., Bryan, A., Sennoune, S., Martinez-Zaguilan, R., Li, G., Gyorke, S., Williams, S. C., Rumbaugh, K. P.: Pseudomonas aeruginosa autoinducer modulates host cell responses through calcium signalling. Cell Microbiol 8, 1601-1610 (2006).

21. Lin, Y. H., Xu, J. L., Hu, J., Wang, L. H., Ong, S. L., Leadbetter, J. R., Zhang, L. H.: Acyl-homoserine lactone acylase from Ralstonia strain XJ12B represents a novel and potent class of quorum-quenching enzymes. Mol Microbiol 47, 849-860 (2003).

22. Park, S. Y., Kang, H. O., Jang, H. S., Lee, J. K., Koo, B. T., Yum, D.Y.: Identification of extracellular $\mathrm{N}$-acylhomoserine lactone acylase from Streptomyces $\mathrm{sp}$. and its application to quorum quenching. Appl Environ Microbiol 71, 2632-2641 (2005).

23. Kaplan, F., Badri, D. V., Zachariah, C., Ajredini, R., Sandoval, F. J., Roje, S., Levine, H. L. F., Robinette, S. L., Alborn, H. T.: Bacterial attraction and quorum sensing inhibition in Caenorhabditis elegans exudates. Journal of Chemical Ecology 35, 878-892 (2009).

24. Draganov, D. I., Teiber, J. F., Speelman, A., Osawa, Y., Sunahara, R., Ladu, B. N.: Human paraoxonases are lactonases with overlapping and distinct substrate specificities. J Lipid Res 46, 1239-1247 (2005).

25. Leadbetter, J. R., Greenberg, E. P.: Metabolism of acyl-homoserine lactone quorum-sensing signals by Variovorax paradoxus. J Bacteriol 182, 6921-6926 (2000).

26. Giskov, M., de Nys, R., Manefield, M., Gram, L., Maximilien, R., Eberl, L., Molin, S., Steinberg, P. D., Kjelleberg, S.: Eukaryotyc interference with homoserine lactone-mediated prokaryotic signalling. J Bacteriol 178, 6618-6622 (1996).

27. Ahmer, B. M.: Cell-to-cell signalling in Escherichia coli and Salmonella enterica. Mol Microbiol 52, 933-945 (2004)

28. Yao, Y., Martinez-Yamount, M. A., Dickerson, T. J., Brogan, A. P.: Structure of the Escherichia coli quorum sensing protein SdiA: Activation of the following switch by acyl homoserine lactones. J Mol Biol 355, 262-273 (2006). 